\title{
DISTRIBUIÇÃO DAS BACTÉRIAS NAS ESTRUTURAS MINERALIZADAS DE DENTES COM NECROSE PULPAR E GRANULOMA APICAL
}

FRANCISCO CARLOS RIBEIRO

Dissertação apresentada à Faculdade de Odontologia de Bauru da Universidade de São Paulo, como parte dos requisitos para a obtenção do grau de Mestre em Odontologia, área de Patologia Bucal.

Orientador:Prof. Dr. Alberto Consolaro

\section{BAURU}




\section{DISTRIBUIÇÃO DAS BACTÉRIAS NAS ESTRUTURAS MINERALIZADAS DE DENTES COM NECROSE PULPAR E GRANULOMA APICAL}

FRANCISCO CARLOS RIBEIRO

Dissertação apresentada à Faculdade de Odontologia de Bauru da Universidade de São Paulo, como parte dos requisitos para a obtenção do grau de Mestre em Odontologia, área de Patologia Bucal.

\section{BAURU}

1997 


\section{Ficha Técnica}

Francisco Carlos Ribeiro: elaboração, redação, digitação e ilustração Alberto Consolaro: orientação, redação, revisão e ilustração

Valdir João Afonso: revisão final e do vernáculo

Maria Helena F. Vasconcelos: revisão e formatação

Karine Piñera: abstract

Alessandro A. Costa Pereira: formatação

Valéria C. T. Ferraz: normatização técnica

Juracy do Nascimento: histotécnica

Fátima Aparecida Silveira: histotécnica

Marcus Thame: cópias e encardenação

Ribeiro, Francisco Carlos

R354d Distribuição das bactérias nas estruturas mineralizadas de dentes com necrose pulpar e granuloma apical / Francisco Carlos Ribeiro. -- Bauru, 1997.

172p. : il. ; $28 \mathrm{~cm}$.

Dissertação. (Mestrado) - Faculdade de Odontologia de Bauru. USP.

Orientador: Prof. Dr. Alberto Consolaro 


\section{FRANCISCO CARLOS RIBEIRO}

17 de dezembro de $1954 \quad$ Nascimento

Jerônimo Monteiro - ES

Filiação

Áureo Ribeiro

Conceição Moraes Ribeiro

$1974-1978$

Curso de Graduação em Odontologia, pela Universidade Federal do Espírito Santo - UFES.

1986

Especialista em Endodontia, pelo Conselho Federal de Odontologia - CFO.

1993

Especialização em Endodontia, pela Universidade Federal do Espírito Santo - UFES.

1993-1997

Professor de Endodontia do Curso de Odontologia da Universidade Federal do Espírito Santo - UFES.

1995-1997

Curso de Mestrado em Patologia Bucal, pela Faculdade de Odontologia de Bauru - USP.

Associações

Associação Brasileira de Endodontia.

Associação Brasileira de Odontologia.

Associação de Pós-Graduandos.

Sociedade Brasileira de Estomatologia.

Sociedade Brasileira de Pesquisa Odontológica. 


\begin{abstract}
Aos meus pais Áureo e Conceição, pela minha formação e pelo constante apoio espiritual;

À minha esposa Angela, e ao nosso filho Lucas, pelo amor e compreensão;
\end{abstract}

Ao amigo Ricardo Bortolotti,

pelo apoio incondicional ao longo desta caminhada e pela amizade sincera,

\title{
Dedico este trabalho
}




\section{Agradecimento Especial}

\section{Ao Professor Doutor ALBERTO CONSOLARO,}

pela orientação magnífica deste trabalho, constante incentivo profissional, e pela lealdade, carinho e amizade a mim dispensados,

meu respeito e gratidão 


\section{Agradeço}

À equipe de Professores e colegas da disciplina de Endodontia da Universidade Federal do Espírito Santo,

sob a coordenação do Professor Doutor Armelindo Roldi, amigo e incentivador à minha carreira de Professor Universitário; e aos demais membros da equipe, Professora Rosana de Souza Pereira e Professor Nevelton Heringer, co-responsáveis pela realização deste mestrado;

Ao Professor Dilson Alves de Almeida,

pelos ensinamentos e pelas oportunidades concedidas no início de minha carreira,

minha amizade e consideração 


\section{Agradeço, ainda}

A DEUS, pelos objetivos alcançados;

Aos meus irmãos, ÁUREO, MÁRCIA, MARIA ÁUREA, MÁRIO, RUTH e VOLMAR, companheiros e amigos;

Ao meu sogro, Sr. HERMES, e minha sogra, Sra. LÚCIA, pelo respeito aos meus ideais e consideração;

Aos meus cunhados, INÁCIO, HOZANA, LUCIER, NICÉA e RICARDO, pelo estímulo e amizade;

Aos companheiros do curso de Mestrado, NILCE, SIMONE, MARIA HELENA, KARINE, EVELYN, JAMES e RENATO, e Doutorado, ALESSANDRO, WASHINGTON, RENATA, DENIS e MÔNICA, pelo convívio e amizade;

Aos Professores do Departamento de Patologia da Faculdade de Odontologia de Bauru, Professor Doutor ALBERTO CONSOLARO, Professor Doutor LUIS ANTÔNIO DE ASSIS TAVEIRA, Professor Doutor SÉRGIO AUGUSTO CATANZARO GUIMARÃES, Professora Doutora DENISE TOSTES OLIVEIRA e Professora VANESSA SOARES LARA, pelos ensinamentos, compreensão e amizade;

Aos funcionários do Departamento de Patologia da Faculdade de Odontologia de Bauru, Sr. JURACY DO NASCIMENTO, Sr. VALDIR JOÃO 


\section{AFONSO, Sra. FÁTIMA APARECIDA SILVEIRA e Sra. MARIA APARECIDA}

DE PAULA, pela valiosa contribuição e amizade;

À Professora MARIA HELENA F. VASCONCELOS, pela colaboração na elaboração deste trabalho e pela amizade;

\section{Ao C.D. MARCO ANTÔNIO FERREIRA DA CUNHA, pela} contribuição durante a fase de obtenção das amostras;

Aos funcionários da Biblioteca e do Setor de Pós-Graduação da Faculdade de Odontologia de Bauru, pela presteza e disponibilidade, 


\section{Agradecimentos Institucionais}

À Direção da Universidade Federal do Espírito Santo - UFES, na pessoa do Magnífico Reitor, Professor Doutor JOSÉ WEBER FREIRE MACEDO;

À Direção da Faculdade de Odontologia de Bauru - USP, na pessoa do Diretor, Professor Doutor DAGOBERTO SOTTOVIA FILHO;

À Comissão de Pós-Graduação da Faculdade de Odontologia de Bauru, na pessoa do Presidente, Professor Doutor JOSÉ CARLOS PEREIRA;

À Direção da Biblioteca da Faculdade de Odontologia de Bauru, na pessoa da Diretora Técnica, Professora Doutora REGINA CÉLIA BATISTA BELLUZZO;

À CAPES, pelo auxílio pecuniário. 


\section{SUMÁRIO}

RESUMO X xii

1 - INTRODUÇÃOO

2 - REVISÃO DA LITERATURA

2.1 - Presença de bactérias no sistema de canal radicular 6

2.2 - Presença de bactérias nas lesões periapicais 26

3 - PROPOSIÇÃO

4 - MATERIAL E MÉTODOS $\quad 47$

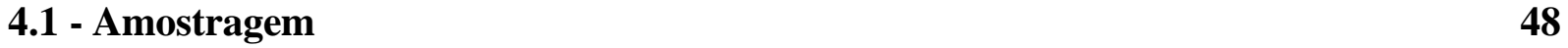

4.1.1 - Obtenção das amostras $\quad 48$

4.1.2 - Seleção das amostras $\quad 48$

$\begin{array}{ll}\text { 4.1.3 - Distribuição das amostras } & 48\end{array}$

4.1.4 - Preparação das amostras $\quad 49$

4.1.4.1 - Exame macroscópico 49

4.1.4.2 - Fixação $\quad 49$

4.1.4.3 - Desmineralização dos espécimes nos grupos A e B 50

4.1.4.4 - Inclusão $\quad 5$

4.1.4.5 - Microtomia $\quad 50$

4.1.4.6 - Coloração $\quad 51$

4.1.4.6.1 - Soluções

4.1.4.6.2 - Procedimentos técnicos $\quad 52$

4.1.4.7 - Coloração de Brown e Brenn $\quad 53$

4.1.4.7.1 - Soluções

4.1.4.7.2 - Procedimentos técnicos

4.1.5 - Análise microscópica $\quad 56$

$\begin{array}{ll}\text { 4.1.6 - Fotomicrografias } & 57\end{array}$

5 - RESULTADOS

5.1 - Grupo A - Dentes com granulomas apicais cortados longitudinalmente $\quad 62$

$\begin{array}{ll}\text { 5.1.1 - Observações relativas ao canal radicular } & 62\end{array}$ 
5.1.2 - Observações relativas à dentina radicular apical

5.1.3 - Observações relativas ao canal cementário

5.1.4 - Observações relativas à superfície apical

5.1.5 - Observações relativas aos granulomas apicais

5.2 - Grupo B - Dentes com granulomas, terços apicais cortados transversalmente

5.2.1 - Observações relativas ao canal radicular

5.2.2 - Observações relativas à dentina radicular apical

5.2.3 - Observações relativas ao canal cementário

5.2.4 - Observações relativas à superfície apical

5.2.5 - Observações relativas aos granulomas apicais

5.3 - Grupo C - Granulomas apicais

5.3.1 - Observações relativas ao granuloma apical

6.1 - Nomenclatura: placa dentobacteriana apical ou biofilme

6.2 - Alterações morfológicas do terço apical radicular

6.3 - Microbiota dos canais radiculares

6.4 - Distribuição das bactérias no lume do canal

6.5 - Distribuição das bactérias na dentina

6.6 - Distribuição das bactérias no canal cementário

6.7 - Distribuição das bactérias na superfície apical

6.8 - Distribuição das bactérias nos granulomas apicais

REFERÊNCIAS BIBLIOGRÁFICAS 


\section{RESUMO}

As bactérias desempenham um importante papel na etiopatogenia das doenças pulpares e periapicais. Com o objetivo de analisar a distribuição das bactérias nas estruturas mineralizadas de dentes portadores de necrose pulpar e nos granulomas apicais, utilizaram-se 32 raízes dentárias com lesões periapicais, firmemente aderidas a seus ápices e 16 lesões isoladas, em cortes obtidos para fins de diagnóstico microscópico com laudos histopatológicos conclusivos de granulomas apicais. Os espécimes foram analisados pela microscopia óptica, empregando-se as técnicas de coloração pela hematoxilina-eosina de Harris e de Brown e Brenn. Os resultados evidenciaram alta frequiência de bactérias Grampositivas e Gram-negativas no lume do canal principal e das ramificações constituintes do delta apical; e também, em menor proporção, nos túbulos dentinários, nos cementoplastos, na superficie radicular externa e nos granulomas apicais.

A partir dos resultados obtidos, considerando-se as limitações inerentes à metodologia empregada, pôde-se verificar:

1- uma elevada freqüência de bactérias no lume do canal do terço apical radicular, com predominância de cocos e bacilos Gram-positivos e Gramnegativos, distribuídos isoladamente ou em colônias, por vezes aderidos à parede do canal; 
2- a presença de bactérias nos túbulos dentinários do terço apical radicular, estendendo-se do terço pulpar circunferencial ao terço superficial circunferencial da dentina, nas formas de cocos e bacilos Gram-positivos e Gramnegativos;

3- a presença de bactérias Gram-positivas e Gram-negativas na superfície radicular apical externa ora isoladas, ora organizadas em placas firmemente aderidas, com predomínio de cocos e bacilos;

4- a presença de bactérias Gram-positivas e Gram-negativas nos granulomas apicais, com predomínio de cocos e bacilos, distribuídos em colônias ou isoladamente, nos espaços extracelulares e/ou no interior de células macrofágicas.

Assim, pôde-se concluir: nos dentes com necrose pulpar e granulomas apicais, as bactérias envolvem todo o sistema de canal radicular, incluindo-se os túbulos dentinários, e freqüentemente os tecidos da região periapical. Mais uma vez, fundamenta-se a necessidade do preparo biomecânico auxiliado por substâncias químicas antibacterianas, emprego de curativos no interior do canal, além do selamento adequado do sistema de canal radicular, em tratamentos endodônticos de dentes com necrose pulpar e lesão periapical crônica. 
1 - INTRODUÇÃO 


\section{1 - INTRODUÇÃO}

As bactérias são os principais agentes etiológicos das pulpopatias e periapicopatias. Os mecanismos específicos desencadeados pela ação ou presença das endotoxinas e outros componentes da parede celular estão relacionados à biopatologia celular, mecanismos reabsortivos e ao processo inflamatório; sendo estes fenônemos largamente estudados ${ }^{58,62,81,90}$. A cárie dentária constitui-se na causa principal de contaminação bacteriana, induzindo no tecido pulpar sucessivas respostas inflamatórias, culminando com a necrose, caso não sejam adotadas medidas terapêuticas ${ }^{21,64,70,72,76,97}$.

A importância da via hematogênica deve ser ressaltada, pois microrganismos patogênicos podem atingir a polpa por intermédio da corrente circulatória, durante bacteriemias transitórias, instalando-se no local, caso condições favoráveis sejam encontradas, como lesões prévias em função do aumento da permeabilidade vascular ${ }^{16,32,85,104}$.

Qualquer microrganismo da cavidade bucal, nasofaringe ou trato gastrintestinal, teoricamente, tem capacidade de infectar o tecido pulpar, mas a microbiota dos canais radiculares infectados inclui um grupo restrito de espécies microbianas. Isto implica em seletividade exercida por fatores intrínsecos e extrínsecos sobre esta microbiota ${ }^{97}$, tais como simbiose, comensalismo, sinergismo, antibiose e o meio ambiente ${ }^{34,35,56}$.

$\mathrm{Na}$ necrose do tecido pulpar, o meio torna-se ideal para a 
proliferação bacteriana e formação de colônias em todo o sistema de canal radicular, inclusive nos túbulos da dentina radicular, desencadeando o desenvolvimento de periapicopatias, às vezes, acompanhadas de reabsorções cementárias e/ou dentinárias $^{28,58,95,102,103}$.

A microbiota do canal radicular infectado é predominantemente anaeróbia ${ }^{6,7,18,26,27,38,97,98}$, das quais um grupo restrito, mais ou menos regular, está presente no lume e na dentina circunjacente. Bactérias aeróbias e anaeróbias facultativas também fazem parte desta microbiota, principalmente na região coronária de dentes com suas câmaras pulpares expostas ao meio bucal por cárie. Infecções anaeróbias ocorrem na presença de tecido necrótico, suprimento sanguíneo compromissado e após infecções por aeróbios e facultativos, capazes de diminuir o potencial de óxido-redução nos tecidos ${ }^{97,98}$.

Até 1960 , as bactérias mais comumente isoladas de canais radiculares infectados eram aeróbias e anaeróbias facultativas, como Streptococcus$\alpha$ hemoliticos, Streptococcus- $\gamma$ hemoliticos, Enterococcus e menos freqüentemente Staphylococcus aureus e Streptococcus- $\beta$ hemoliticos. As técnicas de culturas eram inadequadas para crescimento de anaeróbios estritos. Com o aprimoramento de técnicas de cultura em anaerobiose pôde-se constatar a grande representatividade de espécies bacterianas anaeróbias estritas na microbiota das infecções endodônticas ${ }^{5,6,26,34,35,97,98}$.

O emprego de técnicas endodônticas adequadas promove a eliminação de grande número dessas bactérias, permitindo obter-se considerável porcentagem de sucesso no tratamento endodôntico ${ }^{24,25,31,61,74,84,87,91}$. Em casos de 
selamento inadequado do sistema de canal radicular ${ }^{4,19,37,53}$, bactérias quiescentes nos túbulos dentinários ${ }^{29,33,55,78,89}$, como também placas dentobacterianas ou biofilmes na superfície extra-radicular ${ }^{22,79,102,103}$, podem manter os processos biológicos inflamatórios, reabsortivos e as respostas celulares frente aos agressores locais, circunscrevendo a região afetada.

A partir da releitura dos resultados apresentados na literatura concernente, alguns questionamentos podem ser levantados:

1- todos os canais radiculares com polpas necrosadas apresentam o mesmo índice de contaminação bacteriana?

2- a distribuição das bactérias no lume do canal radicular e nas estruturas mineralizadas é uniforme em todos os dentes com necrose pulpar?

3- qual o envolvimento bacteriano do lume e das estruturas mineralizadas relacionadas com canal cementário em dentes portadores de necrose pulpar?

4- como se distribuem as bactérias e as colônias bacterianas nos granulomas apicais? 


\section{2 - REVISÃO DA LITERATURA}




\section{2 - REVISÃO DA LITERATURA}

Neste capítulo, serão abordados dois aspectos: a presença de bactérias no sistema de canal radicular e nas lesões periapicais crônicas. A forma de apresentação deste capítulo caracteriza-se pela síntese das informações concernentes ao assunto, dos principais trabalhos a partir de 1980 e de algumas referências anteriores, essenciais para a elaboração deste trabalho.

\section{1 - Presença de bactérias no sistema de canal radicular}

Até o final do século XIX, a Endodontia foi praticada de forma empírica; o tratamento endodôntico era sinônimo de obturação do canal radicular, não se tinha conhecimento da importância dos microrganismos. Em 1894, MILLER $^{64}$, examinando restos necróticos pulpares, observou uma grande variedade de células bacterianas. Com isto sugeriu que a microbiota de dentes com câmaras pulpares expostas ao meio bucal, diferenciava-se quanto à localização: se na câmara pulpar ou no canal radicular.

Em 1957, BROWN; RUDOLPH ${ }^{15}$ avaliaram 70 dentes humanos com coroas intactas, sem vitalidade pulpar relacionada a trauma. Nesta avaliação, empregaram culturas aeróbia e anaeróbia, como também microscopia de contraste de fase e de campo escuro. Encontraram bactérias em $90 \%$ dos espécimes, formando uma microbiota mista, com os anaeróbios estritos e facultativos constituindo cerca de $25 \%$ dos isolados e os aeróbios $51 \%$. Houve alta incidência 
de Streptococcus alfa e gama hemolíticos, Difteroides e espécies de Micrococcus. Os autores enfatizaram a importância do uso da microscopia no estudo da microbiota dos canais radiculares, pois foi possível detectar por esta técnica vibriões, espiroquetas e fusiformes, que não apresentaram crescimento em meio de cultura.

A partir de métodos de cultura adequados de aero e anaerobiose, MACDONALD; HARE; WOOD ${ }^{60}$, em 1957, isolaram 71 cepas bacterianas, em amostras de canais, obtidas de 38 dentes humanos, de um total de 46, com coroas intactas e necrose pulpar subseqüente a trauma. Anaeróbios estritos representaram $32 \%$ dos microrganismos isolados. O intervalo entre a agressão e a cultura em oito casos, nos quais nenhum crescimento ocorreu, variou entre um mês e três anos. Nos 38 casos com culturas positivas, o intervalo variou entre duas semanas e vinte anos. As bactérias podem ser a causa de necrose pulpar em alguns casos de trauma dentário sem fratura, concluíram os autores.

Em cinco pré-molares humanos intactos recentemente extraídos, CHIRNSIDE $^{20}$, em 1961, desenvolveu trabalho experimental com o objetivo de verificar invasão bacteriana nos túbulos dentinários de dentes desvitalizados. A preparação dos dentes para o experimento consistiu da remoção do esmalte oclusal, proporcionando uma superfície áspera, para facilitar o acúmulo de placa bacteriana, e seccionamento da coroa na altura da junção amelocementária. A seguir a polpa coronária foi removida via retrógrada e o selamento da abertura apical foi obtido com cimento fosfato de zinco. O dente foi fixado na região de molar de uma prótese parcial removível inferior, permitindo a exposição dentinária da superfície oclusal ao meio bucal. Após 3, 4 e 5 semanas, os dentes 
foram removidos e processados para análise microscópica. Observaram-se placas dentobacterianas aderidas às superfícies dentinárias expostas e bactérias, distribuídas ao acaso, no interior de alguns túbulos dentinários subjacentes.

Para avaliar a importância de microrganismos na etiologia de patologias pulpares, KAKEHASHI; STANLEY; FITZGERALD ${ }^{48}$, em 1965, desenvolveram trabalho em molares de ratos, com sete semanas de idade, sendo 15 animais convencionais e 21 "germ-free". Os dentes foram expostos ao meio bucal com auxílio de brocas carbide número $1 / 2$ montadas em peça de mão. Decorridos 1 a 42 dias, os animais foram sacrificados e o quadrante direito da maxila de cada espécime foi removido em bloco, processado e corado pelas técnicas H.E., tricrômico de Masson, e Brown e Brenn, para análise microscópica. Os espécimes obtidos no oitavo dia do grupo de animais convencionais mostraram remanescente de tecido pulpar vital somente na metade apical das raízes. A porção pulpar coronária apresentava-se necrótica e purulenta, com presença freqüente de colônias bacterianas. Após o oitavo dia, todos os espécimes do grupo de animais convencionais revelaram necrose pulpar com tecido inflamatório crônico e formação de abscessos na região periapical. Dos 21 animais "germfree”, 18 sobreviveram aos procedimentos operatórios. Os dentes apresentavamse com mínima inflamação pulpar, devido ao ato cirúrgico, mas todos com a vitalidade preservada. Aos 14 dias observou-se grande quantidade de matriz dentinária desorganizada, e posteriormente barreira de tecido mineralizado isolando o remanescente pulpar do meio bucal.

Em pré-molares humanos, OLGART; BRÄNNSTRÖM; JOHNSON $^{73}$, em 1974, realizaram trabalho experimental "in vivo" e "in vitro", 
para verificar penetração bacteriana em túbulos dentinários. Os espécimes foram distribuídos em três grupos: dentes com exposição dentinária por fratura intencional da cúspide vestibular, dentes com exposição dentinária por desgaste, e dentes com exposição dentinária por desgaste e tratado com ácido cítrico a 50\% por dois minutos. Todas as áreas de dentina exposta foram deixadas sem proteção por uma semana. A seguir os dentes foram extraídos e desmineralizados em EDTA e submetidos às colorações pela H.E. e Brown e Brenn. Subjacente às áreas de dentina fraturada e desmineralizada, observou-se extensivo crescimento bacteriano em grande número de túbulos dentinários, ao contrário das áreas onde a dentina foi exposta por desgaste sem tratamento ácido, quando poucos túbulos apresentavam-se com bactérias e em profundidade discreta. Os resultados obtidos na presente investigação sugerem que bactérias podem invadir túbulos dentinários de dentina vital intacta, indiferentemente se os túbulos estão abertos ou cobertos por debris.

Quarenta canais radiculares de dentes humanos com polpas necrosadas e coroas intactas, foram investigados por WITTGOW; SABISTON ${ }^{111}$, em 1975, com o propósito de pesquisar a microbiota em meio de cultura. Em 32 amostras observaram crescimento bacteriano, com uma média de 2,56 espécies por dente com cultura positiva, sendo que os bacilos Gram-negativos anaeróbios incluindo espécies de Bacteroides, Fusobacterium e Campylobacter sputorum se fizeram presentes em 84\% dessas amostras; bacilos Gram-positivos anaeróbios: Propionibacterium acnes, Eubacterium alactolyticum, Lactobacillus sp.; cocos Gram-positivos anaeróbios: espécies de Peptostreptococcus; e cocos Gramnegativos anaeróbios como a Veillonella parvula. Os autores sugerem precauções 
durante a terapia endodôntica em dentes com coroas intactas e necrose pulpar, devido à grande freqüência de patógenos nos espécimes analisados.

Em 1980, ZAVISTOSKI et al. ${ }^{113}$ quantificaram por meio de cultura, o número de microrganismos em polpas necróticas de dez dentes humanos com coroas intactas. O número médio de bactérias foi aproximadamente de $10^{7.7}$ unidades formadoras de colônias por grama de tecido amostrado, similar à concentração bacteriana em outros sítios anatômicos infectados do organismo. Sessenta e três por cento das espécies bacterianas isoladas eram anaeróbias, com predomínio de Bacteroides, Propionibacterium acnes e Veillonella. As infecções caracterizaram-se polimicrobianas, encontrando-se em média cinco espécies por amostra.

Com o objetivo de estudar a distribuição de diferentes espécies microbianas em amostras de canais radiculares, FABRICIUS et al. ${ }^{26}$, em 1982, realizaram experimentos em macacos, empregando microscopia de contraste de fase, meios de cultura e colorações de Gram e Giemsa. Polpas de 24 dentes unirradiculados foram expostas à microbiota bucal e após uma semana os acessos cavitários foram selados. Após esses sete dias, foram tomadas amostras do conteúdo do canal radicular de 16 dentes provenientes de dois macacos, dos três grupos experimentais. Aos 90, 180 e 1060 dias, novas coletas foram realizadas após selamento coronário. No período inicial da amostragem, após sete dias, nenhum sintoma clínico ou áreas radiolúcidas foram observados. No final do período experimental, observaram-se sintomas clínicos em sete dentes. Todos os 24 dentes mostraram alterações patológicas registráveis radiograficamente. Quanto à relação de cepas de anaeróbios estritos para facultativos, tomadas dos 
espécimes aos 90 e 180 dias, foi de 1.7 e 6.5, respectivamente; enquanto nos espécimes de 1060 dias a mesma relação foi de 11.3. Bacteroides e os bacilos Gram-positivos anaeróbios foram encontrados em quase todos os espécimes e em ambos os períodos, inicial e final. Porém, em alguns casos não foram observados microrganismos facultativos nas amostras finais. A porcentagem de bactérias anaeróbias estritas nas amostras iniciais dos grupos de 90 e 180 dias, foi de $50 \%$ e $55 \%$, respectivamente, enquanto nas amostras finais os anaeróbios estritos representavam $65 \%$ a $98 \%$ do total de bactérias. Nas amostras iniciais, os principais grupos bacterianos se faziam presentes em significantes proporções, com exceção de cocos Gram-negativos; e nas amostras finais, os bacilos anaeróbios estritos Gram-positivos e Gram-negativos predominavam. Uma notável diferença entre os achados bacterianos em diferentes partes do sistema de canal radicular foi observada. Além disto, observou-se grande superioridade de bactéria anaeróbia estrita, de crescimento lento, na região apical, incluindo bacilos Gram-positivos e Gram-negativos, sugerindo seu relevante papel no desenvolvimento e manutenção da periodontite apical.

A microscopia óptica foi o método utilizado por AKPATA; BLECHMAN $^{1}$, em 1982, para o trabalho experimental em 14 dentes unirradiculados com polpas vitais extraídos por razões periodontais e protéticas, objetivando observar crescimento bacteriano nas paredes da dentina pulpar e nos túbulos dentinários. Os espécimes foram preparados biomecanicamente e esterilizados em gás de óxido de etileno. A seguir foram inoculados com anaeróbios estritos, Bacteroides melaninogenicus e Peptococcus assacharolyticus, e facultativos, Streptococcus faecalis e Streptococcus sanguis. Após o período de incubação de 1 a 3 semanas, os espécimes foram preparados 
para análise microscópica, pela técnica de coloração de Brown e Brenn. No final da primeira semana, poucos túbulos dentinários do terço cervical da raiz haviam sido invadidos por $S$. sanguis, e com duas semanas de incubação já era marcante a presença de bactérias nos túbulos dentinários dos terços cervical e médio, porém a superfície dentinária radicular interna apresentou colônias bacterianas aderidas em toda sua extensão, somente no final da terceira semana. Comparado com $S$. sanguis, os $S$. faecalis invadiram mais túbulos dentinários após três semanas de incubação. Secções transversas tomadas do terço apical da raiz foram as menos freqüentemente invadidas. A presença de Bacteroides e Peptococcus foi relativamente pequena, provavelmente devido ao crescimento lento. Os autores sugerem o modelo experimental para investigação do efeito de medicamentos sobre microrganismos alojados no sistema de canal radicular.

O efeito antimicrobiano do hipoclorito de sódio a 0,5\% como irrigante do canal radicular foi estudado em 1983, por BYSTRÖN; SUNDQVIST $^{18}$, em 15 dentes unirradiculados portadores de necrose pulpar com cavidades fechadas e rarefações ósseas periapicais. Como controle, os autores utilizaram irrigação com soro fisiológico em outros 15 dentes nas mesmas condições. Todos os canais apresentaram inicialmente culturas positivas de microrganismos, totalizando 169 espécies bacterianas isoladas, sendo 80\% de anaeróbios. A maioria das culturas permitiu crescimento de mais de uma espécie, com média de quatro por dente. As mais freqüentemente isoladas foram: Fusobacterium, Eubacterium, Peptostreptococcus e Bacteroides. As soluções irrigadoras foram utilizadas como auxiliares do preparo biomecânico efetuados em cinco sessões com intervalos de 2 a 4 dias. Após o tempo preestabelecido foram feitos testes bacteriológicos dos canais. Os resultados evidenciaram 
culturas negativas em 12 dos 15 espécimes tratados com hipoclorito de sódio a 0,5\% e 8 dos 15 tratados com soro fisiológico. Os resultados sugerem melhor efetividade da solução de hipoclorito de sódio a $0,5 \%$ como irrigante de canais em comparação ao soro fisiológico.

Estudos microscópicos de polpas dentárias expostas ao meio bucal em animais "germ-free" e convencionais foram realizados por PATERSON; WATTS $^{76}$, em 1987, com objetivo de identificar fatores etiopatogênicos das doenças pulpo-periapicais. Os autores utilizaram ratos convencionais e albinos "germ-free" como modelo experimental, expondo as polpas dos molares superiores ao meio bucal por tempo predeterminado de 15 minutos e 1, 2, 3, 7, 8 e 28 dias. Após estes períodos, os animais foram mortos e seus maxilares processados para análises microscópicas. Em curtos intervalos de tempo (até 7 dias), a resposta inflamatória em animais "germ-free" limitou-se à presença de esparsas células inflamatórias localizadas sob os debris da superfície lesada. Em intervalos mais longos, observou-se alta incidência de formação de barreira de tecido mineralizado sobre o remanescente pulpar, porém em alguns espécimes a polpa apresentava-se necrosada, provavelmente devido à impactação alimentar sobre esta. Em animais convencionais, dependendo do tempo de exposição pulpar ao meio bucal, observou-se desde intenso infiltrado inflamatório até necrose pulpar. Os resultados evidenciaram que as bactérias desempenham um importante papel na etiopatogenia das doenças pulpo-periapicais. Trauma mecânico isolado não resultou em processo inflamatório significante do tecido pulpar.

Objetivando testar a eficácia de medicamentos como curativo intracanal, HAAPASALO; ØRSTAVIK ${ }^{39}$, em 1987, desenvolveram "in vitro" 
modelo para infecção de túbulos dentinários a partir de incisivos bovinos intactos, recentemente extraídos. Após remoção do cemento, os tubos de dentina foram ampliados, em média, até $2 \mathrm{~mm}$ de diâmetro e tratados com EDTA a $17 \%$ e hipoclorito de sódio a 5,25\%, com auxílio de ultra-som, para remoção da camada de "smear layer", e a seguir infectados por Enterococcus faecalis em meio apropriado. Decorrido o tempo preestabelecido, os espécimes foram analisados pela microscopia óptica e eletrônica de varredura. No final do primeiro dia de incubação com E. faecalis, observaram-se, em alguns espécimes, bactérias no interior de túbulos dentinários a uma profundidade de $300-400 \mu \mathrm{m}$, a partir do

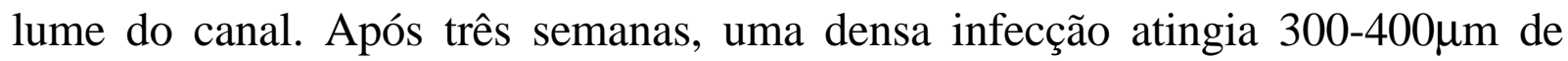
profundidade; uma infecção moderada 400-500 $\mu \mathrm{m}$ e a linha de frente da infecção 800-1000 $\mu \mathrm{m}$. Pela superfície externa do tubo de dentina a infecção atingia a profundidade de 150-200 $\mu \mathrm{m}$ em média, porém, em alguns espécimes onde o cemento foi preservado não houve penetração bacteriana. Quanto à efetividade medicamentosa do $\mathrm{Ca}(\mathrm{OH})_{2}$ (Calasept) e do paramonoclorofenolcanforado (PMCC) os autores obtiveram os seguintes resultados: PMCC tanto na forma líquida quanto gasosa proporcionaram completa desinfecção, após uma hora e um dia, respectivamente. $\mathrm{Ca}(\mathrm{OH})_{2}$ não mostrou eficácia na eliminação de bactérias nas áreas mais internas da dentina após prolongada incubação. Os autores concluíram que o modelo sugerido parece adequado para testes "in vitro" de medicamentos de canais radiculares. Em 1993, PEREZ et al. ${ }^{77}$, empregaram a mesma metodologia, inoculando cepas de Streptococcus sanguis, obtendo resultados semelhantes.

Por métodos adequados de anaerobiose, SUNDQVIST; JOHANSSON; SJÖGREN ${ }^{99}$, em 1989, analisaram 72 dentes unirradiculados portadores de polpas necróticas e periodontites apicais. O objetivo deste estudo 
foi examinar a ocorrência de Bacteroides negros e correlacioná-los com a formação de abscessos apicais. Os resultados evidenciaram uma alta porcentagem de bactérias anaeróbias, cerca de $90 \%$ do total das espécies isoladas. As espécies mais freqüentes foram: Fusobacterium nucleatum, $B$. intermedius, $B$. endodontalis, Peptostreptococcus micros, P. anaerobius, Eubacterium lentum e E. alactolyticum. Bacteroides negros foram isolados de 22 canais radiculares $(30 \%)$. As infecções caracterizaram-se polimicrobianas, e tanto o número médio de cepas bacterianas quanto ao número de células bacterianas foi mais expressivo nos canais com culturas positivas de Bacteroides negros. Estes apresentavam ou desenvolviam abscessos apicais, sugerindo que canais contendo B. intermedius, B. endodontalis e B. gingivalis estavam mais implicados com a formação de exsudato purulento na região apical.

Pela revisão da literatura, KEREKES; OLSEN ${ }^{50}$, em 1990, analisaram as microbiotas de canais radiculares e de bolsas periodontais profundas, com o objetivo de verificar suas correlações. Os autores verificaram similaridades entre as microbiotas endodôntica e periodontal de dentes intactos sem lesões periapicais, indicando a possibilidade de ocorrerem infecções cruzadas entre o canal radicular e bolsa periodontal. Considerando a grande variedade de microrganismos colonizadores de bolsas periodontais versus aqueles isolados de polpas necróticas de dentes com coroas intactas, o número de espécies participante destas infecções cruzadas deve ser limitado. Dentre elas incluem-se: Bacteroides, Fusobacterium, Eubacterium, Spirochetes, Wolinella, Selenemonas e Peptostreptococcus. Conclui-se que infecção crônica no canal radicular ou no ligamento periodontal pode representar um suprimento persistente de bactérias 
para a circulação sangüínea, podendo disseminarem-se para partes não infectadas do dente, como também para outros órgãos do corpo humano.

Por meio de microscopia óptica e eletrônica de transmissão NAIR et al. ${ }^{69}$, em 1990, avaliaram nove dentes tratados endodonticamente e portadores de lesões periapicais persistentes após 4 a 10 anos. Os dentes foram submetidos à cirurgia parendodôntica, e os espécimes obtidos foram processados para análise microscópica. Observaram-se bactérias em quatro espécimes e fungos em duas. Em um dos espécimes as bactérias foram claramente identificadas à microscopia óptica; e nos outros houve necessidade de cortes seriados para detectá-las à microscopia eletrônica. As bactérias identificadas no canal principal, canal acessório e delta apical apresentavam-se ora isoladas, ora em colônias, livres ou aderidas à parede dentinária. Observaram-se também áreas de reabsorções internas ocupadas por densas colônias bacterianas de formas filamentosas, cujas paredes celulares apresentavam-se Gram-positivas. Os autores sugerem que a maioria das lesões persistentes ao tratamento endodôntico estejam relacionadas a fatores que permitam a viabilidade de microrganismos residuais no sistema de canal radicular pós terapia endodôntica.

Utilizando métodos de aero e anaerobiose, BAUMGARTNER; FALKLER $^{6}$, em 1991, estudaram a microbiota dos $5 \mathrm{~mm}$ apicais de dez dentes com exposição pulpar por cárie e portadores de lesões periapicais contíguas com o ápice radicular. Foram isoladas 50 cepas bacterianas, das quais 68\% eram representadas por anaeróbios estritos. Os microrganismos mais freqüentemente isolados foram Actinomyces, Lactobacillus, Bacteroides negros, Peptostreptococcus, Veillonella parvula, Bacteroides buccae, 
Enterococcus faecalis, Fusobacterium nucleatum e Streptococcus mutans. Todos os canais continham anaeróbios estritos e dois canais foram infectados exclusivamente com anaeróbios. Bacteroides negros estavam presentes em seis dos dez canais analisados, sendo cinco cepas de $B$. intermedius e um de B. denticola. Os autores sugerem que a este nível do canal ocorra um processo seletivo, favorecendo as bactérias anaeróbias da microbiota bucal.

A microbiota dos canais radiculares foi verificada em 65 dentes humanos unirradiculados contendo polpas necróticas, paredes das câmara pulpar intacta e evidência radiográfica de reabsorção óssea periapical, por SUNDQVIST $^{97}$, em 1992. Nenhum dos pacientes estava sobre terapia antibiótica. Um total de 353 cepas bacterianas foi isolado, com uma média de 5.4 por canal. Fusobacterium nucleatum foi a mais freqüente (48\%), seguida por outras espécies: Prevotella intermedia, Peptostreptococcus micros, P. anaerobius, Eubacterium alactolybicum, E. lentum e Wolinella recta. Observou-se que com as mudanças ambientais, diferentes espécies bacterianas se associam formando uma cadeia alimentar, pela qual o metabolismo de algumas espécies forneceria nutrientes essenciais para o crescimento de outras, e algumas bactérias liberariam substâncias tóxicas para outras presentes nos canais, caracterizando-se a seletividade da microbiota. Dentre as associações positivas pôde-se observar: $F$. nucleatum e P. micros; Porphyromonas endodontalis, Selenomonas sputigena e Wolinella recta; Prevotella intermedia e P. micros; P. anaerobius e Eubacterium e as associações entre $P$. endodontalis e $P$. intermedia.

Correlacionando a composição da microbiota de canais infectados de pacientes portadores de periodontites apical com sintomas clínicos, 
HASHIOKA et al. $^{43}$, em 1992, realizaram estudo bacteriológico dos canais radiculares de 28 dentes, empregando procedimentos de cultura em condições anaeróbias. Os resultados evidenciaram uma significante relação entre Eubacterium e sintomas clínicos agudos ou crônicos, enquanto, Peptococcus, Peptostreptococcus e Porphyromonas gingivalis relacionados aos sintomas clínicos subagudos. Os autores sugerem ainda outras relações: Peptococcus, Peptostreptococcus, Eubacterium, Porphyromonas e Bacteróides com dor a percussão; além de Porphyromonas e Bacteroides com odor em canais infectados.

Em 1992, HORIBA et al. ${ }^{46}$ avaliaram a ativação do complemento por lipopolissacarídeos (LPS) purificados de Porphyromonas endodontalis, Veillonella parvula e Fusobacterium nucleatum, isoladas de canais radiculares infectados. Quando 10 $\mu \mathrm{g}$ de LPS foram adicionados ao soro humano, o consumo de complemento (C3T) atingiu $15 \%$ a $25 \%$, exceto para a cepa $V$. parvula. Quando 50 $\mu$ g de cada LPS foi adicionado, o consumo de C3T foi maior que 60\%, exceto para $F$. nucleatum, e com $100 \mu \mathrm{g}$ de LPS o consumo de C3T foi maior que $70 \%$, exceto para $V$. parvula. Observou-se ativação de complemento por LPS purificado das três espécies bacterianas, sugerindo sua capacidade de intensificar a resposta inflamatória nos tecidos periapicais.

Em 1992, RIETSCHEL; BRADE ${ }^{82}$ verificaram através de trabalho de revisão da literatura que a estrutura química da endotoxina consiste de um polissacarídeo ou longa corrente de açúcares e uma parte gordurosa chamada de lipídio A. O polissacarídeo varia nas diferentes espécies bacterianas, sendo constituído de uma corrente O-específica e de duas filamentosas. A corrente Oespecífica é o segmento mais variável e a parte que provoca a reação imune 
específica. O lipídio A sempre inclui duas glucosaminas modificadas por um fosfato $\left(\mathrm{PO}_{4}\right)$ e um variável número de ácidos graxos. Esta região, de menor variação na estrutura, traz benefícios, tais como aumento da resistência a infecções e ao câncer.

Em revisão de literatura, SUNDQVIST ${ }^{98}$, em 1994, chegou as seguintes conclusões: bactérias presentes em canais infectados incluem um grupo restrito de espécies comparadas com a microbiota da cavidade bucal. O meio ambiente do sistema de canais radiculares permite o crescimento de bactérias anaeróbias, capazes de fermentação de aminoácidos e peptídeos; e de bactérias, cuja principal fonte energética é obtida pela fermentação de carboidratos quando restringidas pela carência de nutrientes disponíveis. Durante o curso de evolução da infecção pulpar, desenvolvem-se inter-relações entre espécies microbianas, proporcionando mudanças consideráveis na microbiota, constituindo-se associações resistentes e com interdependência mútua. Estas associações são provavelmente baseadas em demandas e relações nutricionais. A patogenicidade da microbiota polimicrobiana do canal radicular está na dependência do sinergismo bacteriano.

Após revisão crítica da literatura, OGUNTEBI ${ }^{72}$, em 1994, sugeriu que o microambiente dos túbulos dentinários parece favorecer o crescimento de algumas espécies bacterianas sem restrições à natureza da causa do processo infeccioso. Estas constituem um importante reservatório bacteriano dos canais radiculares infectados, sendo capazes de reinfectá-lo durante ou após o tratamento endodôntico. $\mathrm{O}$ caminho da reinfecção parece estar relacionado com infiltrações coronárias causadas por restaurações temporárias ou permanentes inadequadas, e possivelmente de bactérias alojadas nos túbulos dentinários, multiplicando-se em 
condições favoráveis. $\mathrm{O}$ autor sugeriu mais investigações para identificar melhor estes agentes microbianos e resgatar sistemas que assegurem patência dos túbulos dentinários, favorecendo um melhor contato entre agente antimicrobiano e bactéria.

Por meio de cultura em anaerobiose, testes bioquímicos e antibiograma, DEBELIAN; OLSEN; TRONSTAD ${ }^{23}$, em 1995, desenvolveram trabalho com o propósito de investigar a incidência de bacteriemia seguida de tratamento endodôntico em 26 dentes com necrose pulpar e portadores de periodontite apical crônica. Em 13 dentes (grupo 1) os canais foram instrumentados $2 \mathrm{~mm}$ além do forame apical, e nos outros 13 (grupo 2) a $1 \mathrm{~mm}$ aquém do forame. Todos os canais continham microrganismos, variando de 1 a 11 espécies por amostra. As espécies mais freqüentemente isoladas foram: Fusobacterium nucleatum, Prevotella intermedia, Propionibacterium acnes, Propionibacterium propionicus, Eubacterium lentum, Peptostreptococcus anaerobius e Actinomyces israelii. Em 7 dos 13 pacientes do grupo 1, e em 4 do grupo 2, microrganismos foram recuperados da circulação sangüínea. Aos testes bioquímicos e antibiogramas observaram que os microrganismos isolados do canal radicular e sistema circulatório tinham perfis idênticos aos microrganismos do paciente, sugerindo fortemente que microrganismos recuperados do sangue tinham o canal radicular como suas fontes.

Com o propósito de investigar a topografia da microbiota dos canais radiculares infectados e o grau de penetração bacteriana nos túbulos dentinários, SEN; PISKIN; DEMIRCI ${ }^{92}$, em 1995, examinaram pela microscopia 
eletrônica de varredura dez primeiros molares humanos, cinco superiores e cinco inferiores. Constatou-se em seis espécimes, a presença acentuada de bactérias em forma de cocos e bastonetes, constituindo-se em colônias, principalmente nas paredes dos canais, e também, em grau variado, penetrando nos túbulos dentinários dos terços médio e apical das raízes. A profundidade atingida pelas bactérias nos túbulos dentinários foi em média de 50æm, somente em dois espécimes algumas atingiram 150æm de profundidade. Penetração bacteriana não foi comum a todos os túbulos dentinários, enquanto aglomerados bacterianos eram evidentes em alguns túbulos, outros permaneciam isentos de suas presenças. Além de cocos e bastonetes, observaram-se fungos em quatro espécimes, e estes encontravam-se juntos às paredes dos canais. Como a instrumentação mecânica auxiliada por substâncias químicas irrigadoras não elimina todos os microrganismos do sistema de canais radiculares infectados, os autores sugerem o emprego de agentes antimicrobianos intracanal entre visitas, como terapia complementar.

Por meio de microscopia óptica e eletrônica de varredura, NAGAOKA et al. ${ }^{67}$, em 1995, realizaram estudo em terceiros molares humanos com o objetivo de verificar os efeitos da polpa dentária sobre penetração bacteriana nos túbulos dentinários. Trinta e oito espécimes foram empregados; 19 foram desvitalizados e submetidos a tratamento endodôntico e no restante a vitalidade foi preservada. Em todos os espécimes foram preparadas cavidades classe V de aproximadamente $2.5 \mathrm{~mm}$ de diâmetro por $2.0 \mathrm{~mm}$ de profundidade e expostas ao meio bucal. Decorridos 30 e 150 dias, os dentes foram extraídos e processados para análise microscópica. Após 30 dias houve pequena invasão bacteriana nos túbulos dentinários de ambos os grupos, sem diferença estatística. 
Entretanto, decorridos 150 dias de exposição a invasão bacteriana para o interior dos túbulos dentinários dos dentes desvitalizados foi significantemente maior. Os resultados sugerem que os prolongamentos odontoblásticos, matriz extracelular e o fluido dentinário dificultam a penetração bacteriana nos túbulos dentinários dos dentes vitalizados.

Em anaerobiose, KONTAKIOTIS; NAKOU; GEORGOPOULOU $^{52}$, em 1995, realizaram trabalho experimental empregando 20 espécies diferentes de bactérias anaeróbias estritas e 20 facultativas isoladas de canais radiculares infectados de dentes humanos. Para cada espécie bacteriana dois grupos foram estudados. O grupo experimental incluía uma placa de ágarsangue com microrganismos e uma outra placa aberta contendo $32 \mathrm{~g}$ de pasta de hidróxido de cálcio na proporção 6:4 (pó/solução fisiológica). O grupo controle incluía somente uma placa contendo as mesmas espécies bacterianas. Após 72 horas de incubação, o número de bactérias na superfície foi contado em ambos os grupos. A média numérica de bactérias anaeróbias estritas foi de 296 × $10^{6}$ para o grupo experimental e $639 \times 10^{7}$ para o controle; e de anaeróbias facultativas foi de $138 \times 10^{7}$ e $721 \times 10^{9}$ para os grupos experimental e controle, respectivamente. Os resultados evidenciaram uma quantidade significantemente menor de anaeróbios estritos e facultativos no grupo experimental, fornecendo grandes evidências do efeito antimicrobiano do hidróxido de cálcio pela absorção de dióxido de carbono.

Para verificar a permeação de endotoxinas bacterianas através da dentina na ausência de pressão de filtração, NISSAN et al. $^{71}$, em 1995, desenvolveram trabalho utilizando modelos de dentina obtidos a partir de cinco terceiros molares humanos imaturos impactados e endotoxina proveniente de Actinobacillus actinomycetemcomitans. Após a exodontia, os dentes tiveram suas 
raízes descartadas, a polpa coronária foi removida, e a cavidade pulpar ampliada até que pudesse conter $0,1 \mathrm{ml}$ de líquido. Uma cavidade classe I foi preparada na superfície oclusal dos dentes nas mesmas dimensões da cavidade pulpar, interpostas por uma camada de dentina de $0,5 \mathrm{~mm}$. Para maximizar a permeabilidade dentinária, as superfícies oclusal e pulpar foram condicionadas com ácido fosfórico a $37 \%$ por 30 segundos, lavadas e as peças foram montadas em aparato específico. A câmara oclusal foi preenchida com $0,1 \mathrm{ml}$ da solução de endotoxina na concentração de $100 \mu \mathrm{g} / \mathrm{ml}$, e a câmara pulpar com $0,1 \mathrm{ml}$ de água destilada. Os resultados mostraram difusão da endotoxina em quatro espécimes em concentrações variadas, atingindo níveis consideráveis no período de quatro horas e 30 minutos a 24 horas. Os autores sugerem novas pesquisas para determinar se a endotoxina pode permear através de camadas mais espessas de dentina em dentes submetidos à oclusão funcional.

Com o propósito de identificar bactérias associadas com alterações patológicas na polpa dentária e periápice, BAUMGARTNER; WATKINS; BAE ${ }^{7}$, em 1996, desenvolveram trabalho, sobre condições anaeróbias, empregando 43 dentes humanos com coroas intactas associados com rarefações periapicais. Foram isoladas 348 cepas bacterianas, das quais $83 \%$ eram de anaeróbios. Bacteroides negros, como Prevotella intermedia, $P$. nigrescens, $P$. melaninogenica, Porphyromonas gingivalis e $P$. endodontalis estavam presentes em 54\% das amostras. Outras espécies bacterianas freqüentemente isoladas foram Fusobacterium nucleatum, Peptostreptococcus micros, Streptococcus morbillorum e $P$. oralis. Os autores encontraram uma média de oito espécies bacterianas por amostra, caracterizando assim uma infecção mista. 
Em 1996, LOVE$^{59}$ estudou a distribuição bacteriana nos túbulos dos terços cervical, médio e apical da dentina radicular empregando como modelo experimental dentes humanos recém-extraídos e isentos de cárie. O preparo dos espécimes consistiu de instrumentação dos canais radiculares, esterilização, inoculação com Streptococcus gordonii e incubação em meio de cultura em anaerobiose por sete dias. À luz dos resultados observaram-se padrão similar de invasão tubular nos terços cervical e médio das raízes, caracterizada por uma intensa camada superficial de penetração envolvendo a maioria dos túbulos, mas com distribuição e profundidade variáveis. Diferentemente, ocorreu no terço apical, onde se observaram poucos túbulos infectados, salvo em um caso onde a dentina da camada superficial externa encontrava-se desnuda, devido à reabsorção externa. A extensão média de penetração bacteriana nos terços médio e cervical foi de $200 \mu \mathrm{m}$ e no apical $60 \mu \mathrm{m}$. Os resultados indicam que há uma variação na extensão de invasão bacteriana de túbulos dentinários de canais radiculares infectados. O padrão de invasão favoreceria uma técnica de instrumentação endodôntica que resultasse em preparação apical mínima, devido à mínima e limitada penetração, mas que o alargamento no sentido coronal removesse a grande quantidade de dentina infectada nos terços cervical e médio.

Estudo desenvolvido "in vitro" por SIQUEIRA JÚNIOR; UZEDA; FONSECA ${ }^{94}$, em 1996, objetivou investigar a penetração de bactérias anaeróbias em túbulos dentinários de cilindros de dentina obtidos a partir de incisivos bovinos recém-extraídos. Estes foram alargados a um diâmetro estandardizado de $2 \mathrm{~mm}$ e submetidos à solução de ácido cítrico por três minutos para remoção do magma dentinário, conseqüientemente permitir a manutenção da patência dos túbulos dentinários. As seguintes espécies bacterianas, 
Porphyromonas endodontalis, $P$. gingivalis, Fusobacterium nucleatum, Actinomyces israelii, Propionibacterium acnes e Enterococcus faecalis foram inoculadas nos cilindros de dentina e os espécimes incubados em anaerobiose. À microscopia eletrônica de varredura observou-se que todas as espécies bacterianas empregadas no experimento foram capazes de penetrar nos túbulos dentinários em diferentes profundidades. A maioria dos túbulos continha células bacterianas em seu interior a uma grande extensão. Bactérias localizadas nos túbulos dentinários a uma pequena distância da superfície pulpar podem ser removidas pela preparação mecânica dos canais radiculares ou serem destruídas pela ação química das soluções irrigadoras; opostamente, aquelas localizadas mais profundamente podem permanecer. Se a obturação do sistema de canal radicular não permitir um selamento adequado, percolação de fluidos teciduais ou saliva servirá de substrato para estas bactérias remanescentes que crescerão e multiplicarão podendo causar danos aos tecidos periapicais.

Com hidróxido de cálcio em diferentes veículos, ESBERARD; CARNES JÚNIOR; DEL RIO ${ }^{25}$, em 1996, desenvolveram trabalho experimental com o objetivo de verificar alterações de $\mathrm{pH}$, em diferentes intervalos de tempo, em cavidades preparadas nas superfícies externas das raízes. Em 40 dentes humanos unirradiculares e extraídos por razões diversas, os canais radiculares foram instrumentados com auxílio de hipoclorito de sódio a 2,5\%, e a seguir confeccionadas cavidades de $0,75 \mathrm{~mm}$ de profundidade por $1,5 \mathrm{~mm}$ de diâmetro nas superfícies externas das raízes, abrangendo os terços cervical, médio e apical. Os dentes foram divididos em quatro grupos distintos, A, B, C, D, e seus canais foram, respectivamente, preenchidos com pasta aquosa de hidróxido de cálcio, hidróxido de cálcio com paramonoclorofenol canforado e pasta Pulpdent, 
exceto o grupo $\mathrm{D}$, que serviu de controle. Os resultados demonstraram que o $\mathrm{pH}$ das cavidades preparadas na superfície das raízes aumentou. O padrão de alteração do $\mathrm{pH}$ foi qualitativamente similar nas regiões cervical, média e apical das raízes, independente do tipo de hidróxido de cálcio utilizado na obturação. Houve rápido aumento do $\mathrm{pH}$, oscilando em torno de dez, em todos os grupos experimentais onde se empregaram diferentes veículos com hidróxido de cálcio, por períodos de 3 a 120 dias. $\mathrm{O}$ ambiente alcalino proporcionado pela pasta de hidróxido de cálcio pode interferir com a atividade reabsortiva de osteoclastos, que requerem um ambiente ácido para realizar a dissolução mineral.

Em 1996, RIVERA; ZERR; DRAKE ${ }^{83}$ realizaram estudos "in vitro" empregando meios de culturas em anaerobiose, com o objetivo de avaliar a longevidade do efeito antimicrobiano do hidróxido de cálcio sobre repetidas exposições à ação bacteriana. As seguintes espécies bacterianas utilizadas no experimento, Peptostreptococcus micros, Streptococcus anginosus e Fusobacterium nucleatum, foram expostas repetidamente ao hidróxido de cálcio por 5-7 vezes. Os resultados evidenciaram diminuição na atividade antimicrobiana do hidróxido de cálcio em exposições repetidas a diferentes espécies bacterianas.

\section{2 - Presença de bactérias nas lesões periapicais}

Vários estudos têm sido realizados objetivando localizar e identificar bactérias em lesões periapicais crônicas. Devido à recuperação bacteriana em diferentes situações e examinadas com diferentes técnicas,

tornavam os resultados conflitantes ${ }^{47,68,102,103,112}$. Porém com o surgimento de novas técnicas, as dúvidas estão sendo dirimidas. 
Os primeiros estudos para detectar bactérias no interior de lesões periapicais crônicas surgiram devido o envolvimento desses microrganismos com possíveis implicações de ordem sistêmica. Em 1926, HADEN ${ }^{40}$ desenvolveu um trabalho experimental em culturas periapicais de 1500 dentes recém-extraídos. Os resultados evidenciaram culturas positivas em 1091 amostras, sendo 963 somente para Streptococcus, e os restantes, além de Streptococcus observou-se crescimento de Staphylococcus e bacilos Gram-positivos.

Em 1934, BOYLE ${ }^{13}$, empregando métodos de coloração para tecidos, como Giemsa, Gram e eosina-azul de metileno, evidenciou bacilos Grampositivos no interior de células fagocitárias na porção central de um granuloma periapical.

Numa tentativa de eliminar resultados falso-positivos durante os procedimentos de obtenção do material da região periapical para análise, HEDMAN $^{45}$, em 1951, desenvolveu uma técnica que consistia em introduzir uma cânula no canal após seu debridamento, e impulsionar uma sonda por dentro dessa cânula e colher material da região periapical. Da análise do material proveniente de 82 casos de lesões periapicais residuais após terapia endodôntica, 56 permitiram crescimento bacteriano em meio de cultura. $\mathrm{O}$ autor sugere que pelas evidências deste estudo, é aceitável que em uma grande porcentagem de casos de dentes com canais radiculares infectados e portadores de patologias periapicais, os tecidos periapicais estejam infectados.

Por meio de cultura, ALIN; $\mathrm{AGREN}^{2}$, em 1954, estudaram amostras dos ápices radiculares e das lesões periapicais de 53 pacientes, tratados 
cirurgicamente. Em 14 lesões diagnosticadas como cistos, observaram crescimento de Staphylococcus aureus e albus, Streptococcus do grupo viridans e Lactobacillus.

Em cultura com aerobiose, GROSSMAN ${ }^{36}$, em 1959, analisou 150 lesões periapicais obtidas a partir de dentes desvitalizados. Estas lesões foram coletadas cirurgicamente e diagnosticadas como abscessos subagudos, abscessos crônicos, granulomas e cistos. De 109 espécimes consideradas não contaminadas, $93(85,3 \%)$ proporcionaram resultados negativos. $\mathrm{O}$ autor sugere que áreas inacessíveis, proporcionadas por necrose óssea, formam uma área protetora para microrganismo, impedindo sua eliminação pelas células polimorfonucleares.

Com o propósito de investigar bactérias na região periapical, SHINDELL ${ }^{93}$, em 1961, desenvolveu um trabalho por meio de cultura, empregando 63 dentes despolpados e portadores de imagem radiográficas radiolúcidas, sugerindo periapicopatias crônicas. Em três amostras encontrou-se positividade. Segundo o autor, invasão dos tecidos periapicais por microrganismos provenientes do canal radicular é um processo difícil de ocorrer, e que a evidência radiográfica da lesão periapical não significa necessariamente presença de microrganismos.

De acordo com BIRCH; MELVILLE; NEUBERT ${ }^{10}$, em 1964, o sucesso de uma técnica para amostragem bacteriológica depende da habilidade em se obter amostras sem contaminação por microrganismos das áreas vizinhas, e ainda organismos representativos do sítio selecionado. Certas variáveis, como acessibilidade da área a ser amostrada, contaminação do campo operatório e do 
instrumental e métodos utilizados para avaliação da lesão, podem influenciar os resultados.

Baseado nessas considerações, MELVILLE; BIRCH ${ }^{63}$, em 1967, analisaram amostras de lesões periapicais obtidas de cirurgias parendodônticas. Em $22(34 \%)$ de 64 amostras, as culturas foram negativas, tanto da lesão quanto das superfícies óssea e bucal. Os autores sugerem que a região periapical pode estar estéril, mesmo quando bactérias estão presentes no compartimento pulpar.

Objetivando localizar bactérias no interior de lesões apicais crônicas, WINKLER; MITCHELL; HEALEY ${ }^{110}$, em 1972, estudaram 15 dentes humanos acompanhados por lesões periapicais aderidas ao ápice. Após processamento de rotina, os espécimes foram corados pelos métodos de Gram modificado para tecidos e H.E., e analisados microscopicamente. Os diagnósticos dados foram de granulomas periapicais. Os canais apresentavam-se com grande quantidade de bactérias em seus lumes, e com certa freqüência também nos túbulos dentinários. Em 13 dos 15 espécimes, microrganismos apresentavam-se uniformemente dispersos na lesão periapical, em concentrações de leve a moderada. Muito raramente foram notadas bactérias Gram-negativas nos cortes microscópicos. O predomínio foi de cocos e bacilos Gram-positivos, nos canais radiculares e nas lesões periapicais.

Por meio de métodos histobacteriológico e histopatológico, LANGELAND; BLOCK; GROSSMAN ${ }^{54}$, em 1977, analisaram 35 amostras de lesões periapicais crônicas, removidas cirurgicamente de dentes com canais obturados. Após fixação e processamento, os cortes obtidos dos espécimes foram 
corados em H.E, Brown e Brenn e tricrômico de Masson. Bactérias foram vistas somente em um espécime, e estas estavam intimamente relacionadas com polimorfonucleares. Os autores sugerem presença de componentes bacterianos nas lesões periapicais, embora não fosse possível detectá-los pelos métodos utilizados.

O papel etiológico das bactérias na indução da inflamação periapical foi demonstrado por MÖLLER et al. ${ }^{65}$, em 1981, utilizando macacos como modelo experimental. Do total de 78 dentes que tiveram suas polpas assepticamente necrosadas, 26 foram selados e mantidos livres de microrganismos, e os 52 remanescentes permaneceram expostos à microbiota indígena bucal por sete dias. Decorridos 6 a 7 meses, os autores observaram que os dentes com polpas contaminadas desenvolveram periodontites apicais, os canais continham anaeróbios facultativos como Streptococcus alfa hemoliticos e Enterococcus, e anaeróbios estritos como Bacteroides, Eubacterium, Propionibacterium, Peptococcus e Peptostreptococcus, bactérias da microbiota indígena bucal. Os canais não infectados apresentaram-se estéreis no final do experimento, observando-se na maioria dos casos, ausência de inflamação dos tecidos periapicais, e quando presente, apenas discreta.

Com o objetivo de comparar os efeitos de dipeptídeo muramyl (MDP) e lipopolissacarídeo (LPS) sobre a reabsorção óssea, RAISZ et al. ${ }^{81}$, em 1982, desenvolveram trabalho "in vitro" utilizando como modelo de estudo ossos longos de feto de ratos em meio de cultura adequado. A reabsorção óssea foi mensurada pela liberação de ${ }^{45} \mathrm{Ca}$ previamente incorporado ao rádio e cúbito em fetos de 19 dias. Os espécimes foram corados pela hematoxina-croceína-fucsina e azul de toluidina. Tanto os LPS como o MDP aumentaram a liberação de enzimas 
lisossomais em proporção a seus efeitos sobre a liberação de ${ }^{45} \mathrm{Ca}$. Os LPS também aumentaram marcadamente a atividade da colagenase no meio, mas o MDP não. Os resultados indicam que produtos bacterianos quimicamente diferentes estimulam reabsorção óssea "in vitro".

Na pesquisa de SCHONFELD et al. ${ }^{88}$, em 1982, lesões apicais obtidas cirurgicamente, de dentes sem envolvimento periodontal, foram analisadas para verificar a atividade endotóxica. Os tecidos foram examinados microscopicamente e classificados como granuloma, cicatriz apical e cisto. Após homogeneização, os tecidos foram submetidos ao ensaio de Limulus amebocyte lysate (LAL) para detectar endotoxina. Endotoxina foi identificada em $75 \%$ das amostras de tecidos de lesões periapicais com sinais de inflamação e em $20 \%$ de tecidos sem sinais de inflamação. Produtos bacterianos em tecidos periapicais podem conduzir à periapicopatias, independente da presença de bactérias viáveis no local.

Na pesquisa de STABHOLZ; SELA ${ }^{95}$, em 1983, foram utilizados caninos de gatos com o objetivo de verificar o possível papel de fragmentos de Streptococcus mutans na patogênese de patologias pulpares e periapicais. Fragmentos bacterianos foram injetados em suspensão nas câmaras pulpares dos espécimes experimentais, e no grupo controle injetou-se soro fisiológico estéril. Após seis meses os dentes foram radiografados, removidos em blocos e preparados para análise microscópica. Ao exame radiográfico, observaram-se áreas radiolúcidas na região periapical de todos os dentes injetados com $S$. mutans. Ao exame microscópico, as polpas dos caninos infectados mostraram um quadro de necrose parcial ou total da polpa. Este consistia de ausência completa 
de elementos celulares incluindo odontoblastos, fibroblastos e células inflamatórias. A região periapical destes dentes demonstrava um infiltrado crônico de células mononucleares, e em algumas áreas, formação de abscessos pôde ser observada, acompanhados de reabsorção óssea, cementária e dentinária. Concluise que a presença de componentes da parede celular bacteriana e outros elementos nocivos podem explicar o insucesso em alguns tratamentos de canal, mesmo que uma cultura negativa seja obtida antes da obturação.

Com métodos imunocitoquímicos para Actinomyces naeslundii, A. israelii e Arachnia propionica, HAPPONEN et al. ${ }^{42}$, em 1985, analisaram sete lesões periapicais com colônias bacterianas, identificadas em exames microscópicos de rotina. Estas lesões consistiam de três cistos radiculares, três granulomas periapicais e um abscesso dento alveolar. Os resultados evidenciaram a presença de colônias de Actinomyces naeslundii e Arachnia propionica em todos os espécimes analisados. As três espécies bacterianas foram encontradas somente em uma amostra. Ambos, A. israelii e A. propionica em três amostras; e um de cada espécie nas três biópsias remanescentes. Os autores sugerem métodos imunocitoquímicos para o diagnóstico de actinomicose periapical.

Em 1986, HAPPONEN ${ }^{41}$ estudou 16 casos de lesões periapicais inflamatórias tratadas cirurgicamente onde a presença de uma ou mais espécie de Actinomyces ou Arachnia propionica foram demonstradas em biópsias de rotina por métodos imunocitoquímicos. Todos os pacientes tinham uma longa e complicada história endodôntica. Aspectos clínicos foram de infecções persistentes com várias exarcebações e fistulação antes da cirurgia periapical. As lesões foram diagnosticadas microscopicamente como: oito granulomas, seis 
cistos e dois abscessos. Estudos imunocitoquímicos revelaram presença de Actinomyces israellii em 13 lesões, A. naeslundii em seis lesões e Arachnia propionica em dez. Mais de uma espécie foi encontrada em nove casos, formando colônias isoladas. Os autores sugerem terapia cirúrgica incluindo curetagem da área infectada com ressecção das raízes envolvidas como tratamento de escolha para actinomicoses periapicais.

Utilizando microscopia óptica e eletrônica de varredura, NAIR ${ }^{68}$, em 1987, examinou 31 dentes humanos portadores de lesões periapicais e sem tratamento endodôntico. Cinco destes dentes apresentavam-se sintomáticos. Em microscopia óptica, os resultados mostraram presença bacteriana em todos os canais, constituindo uma microbiota mista, representada por cocos, bacilos, formas filamentosas e espiroquetas. Em microscopia eletrônica de varredura, camadas bacterianas puderam ser identificadas, aderidas às paredes dentinárias, mas a grande maioria permanecia suspensa no conteúdo aquoso do canal, ou livres entre um grande número de polimorfonucleares. Somente uma pequena porção das lesões periapicais revelou bactérias dentro do corpo das lesões.

Em relato de uma infecção periapical acompanhada de fístula de incisivo superior direito, onde não se obteve sucesso com tratamento conservador, incluindo preparo químico mecânico, medicação local com hidróxido de cálcio e administração sistêmica de antibióticos, HAAPASALO et al. ${ }^{38}$, em 1987, isolaram bactérias do canal radicular e da lesão periapical, por meio de teste bacteriológico e biópsia por aspiração. Após tratamento cirúrgico complementar, obteve-se o reparo da região apical. Os autores sugerem que bactérias na região periapical contribuíram para a persistência da infecção. 
Utilizando microscopia óptica e técnicas bacteriológicas anaeróbias, BYSTRÖN et al. ${ }^{17}$, em 1987, realizaram estudos em 79 dentes humanos com infecção pulpar e portadores de lesões periapicais. Os canais radiculares só foram obturados após apresentarem-se negativos aos testes bacteriológicas, e com esse objetivo utilizou-se preparo biomecânico auxiliado por soluções químicas irrigadoras, e entre sessões, hidróxido de cálcio como curativo intracanal. Após efetuados os tratamentos endodônticos, estes foram proservados até cinco anos. Do total de 79 lesões, 67 repararam por completo. Em sete casos, o tamanho das lesões diminuiu, mas não completamente, no período de dois anos; porém em cinco casos houve persistência do processo infeccioso. Estes dentes foram submetidos à cirurgia apical e os espécimes processados para análise microscópica. Com o auxílio da imunocitoquímica identificaram-se, em duas das lesões, as seguintes espécies bacterianas: Actinomyces israelii, Actinomyces naeslundii e Arachnia propionica. Em outro espécime havia raspas de dentina na intimidade dos tecidos periapicais. Os autores acreditam em várias razões para a persistência de lesões em dentes tratamentos endodonticamente: bactérias podem persistir no canal dentinário, em túbulos dentinários expostos à superfície radicular, nas lacunas de cemento celular ou em foraminas apicais; raspas de dentina ou cemento contaminados podem ser lançados para os tecidos periapicais durante o preparo biomecânico. Além disso, algumas bactérias do gênero Actinomyces e Arachnia podem dificultar o reparo, por sobreviverem nos tecidos periapicais.

Um trabalho experimental para induzir lesões periapicais em macacos foi desenvolvido por PASCON; GREMSKY; LANGELAND ${ }^{75}$, em 1989, com o propósito de avaliar a presença e a localização de bactérias, tanto 
nos canais como nas lesões. Placas dentárias coletadas de dentes contíguos foram colocadas na câmara pulpar, com posterior fechamento das cavidades. Após períodos de observação de 1, 4, 8 e 20 semanas, os animais foram sacrificados, os maxilares removidos em blocos, contendo a raiz dentária e tecido periapical com a lesão. A seguir as peças foram processadas para análise em microscopia óptica, utilizando a coloração de Brown e Brenn e eletrônica. Os resultados evidenciaram bactérias ao longo dos canais radiculares, túbulos dentinários e nos tecidos da região periapical em áreas de necrose.

Em 1990, FUKUSHIMA et al. ${ }^{30}$ realizaram um estudo em 21 dentes humanos tratados endodonticamente e portadores de lesões periapicais, porém assintomáticos. Após a exodontia, os dentes foram seccionados a $5 \mathrm{~mm}$ do ápice radicular e submetidos a um meio de cultura adequado. $\mathrm{O}$ exame bacteriológico revelou cultura positiva em 13 espécimes, com predomínio de bactérias anaeróbias. As espécies mais encontradas foram: Bacteroides, Eubacterium, Peptostreptococcus e Peptococcus. A análise em microscopia eletrônica de varredura, dos espécimes de culturas positivas e em dois espécimes de culturas negativas, mostrou bactérias entre o material obturador e o limite superior do forame apical, mas na superfície externa da raiz e região apical não se notou presença bacteriana.

Ainda em 1990, IWU et al. ${ }^{47}$ examinaram, em microscopia óptica, 16 granulomas periapicais provenientes de dentes tratados endodonticamente, empregando cultura para anaeróbios. Em 14 lesões as culturas foram positivas após os procedimentos técnicos, com uma concentração média de $10^{2.2}$ bactérias $/ \mathrm{ml}$ de tecido homogeneizado. Foram isoladas 47 espécimes de 
bactérias, sendo 26 (55\%) de anaeróbios facultativos e 21 (45\%) de anaeróbios estritos, com uma variação de 1 a 6 espécies por amostra. As espécies bacterianas mais comumente encontradas, incluindo anaeróbios facultativos e estritos foram: Veilonella, Streptococcus milleri, Streptococcus sanguis, Actinomyces naeslundii, Propionibacterium acnes e Bacteroides.

Em 1990, BARNET; STEVENS; TRONSTAD ${ }^{5}$ demonstraram a presença de Bacteroides intermedius em um granuloma periapical, analisado por imunofluorescência indireta. Fluorescência positiva foi observada em várias áreas da lesão, evidenciando a presença de Bacteroides intermedius. Realizaram-se também culturas para anaeróbios, com material colhido próximo ao forame apical. Os resultados evidenciaram infecção mista, constituída por Bacteroides intermedius, Actinomyces naeslundii e outros Bacteroides.

Com o objetivo de determinar o tempo necessário para a bactéria penetrar uma extensão padronizada de canais radiculares obturados e expostos intencionalmente, TORABINEJAD; KETTERING ${ }^{101}$, em 1990, desenvolveram um trabalho experimental "in vitro" empregando duas espécies bacterianas como contaminantes; Proteus vulgaris, bactéria com capacidade de mover-se, e Staphylococcus epidermidis, sem mobilidade. Os canais radiculares de 45 dentes foram instrumentados e obturados com guta-percha e cimento à base de óxido de zinco e eugenol, utilizando a técnica da condensação lateral. A porção coronária da guta-percha foi removida, até permitir um remanescente de $10 \mathrm{~mm}$ de obturação do canal. Os espécimes foram divididos em grupos e a seguir expostos em suas porções coronárias à saliva artificial contaminada com S. epidermidis e $P$. vulgaris. Os resultados evidenciaram que $88 \%$ e $85 \%$ dos canais inoculados 
com S. epidermidis e P. vulgaris tornaram-se totalmente contaminados em 30 e 66 dias, respectivamente; sugerindo que a motilidade pode não ser um fator determinante na taxa de penetração aos ápices.

Por meio de microscopia eletrônica de varredura, TRONSTAD; BARNETT; CERCONE ${ }^{102}$, em 1990, estudaram a superfície radicular dos terços apicais, de dez dentes portadores de lesões periapicais persistentes após tratamento endodôntico convencional, removidos cirurgicamente. Observaram-se microrganismos em todos os espécimes analisados ora formando colônias, ora agregados localizados em áreas irregulares da superfície radicular entre feixes de fibras colágenas e células. Além de cocos e bacilos, formas filamentosas ou fibrilares foram também identificadas. Os autores sugerem que a procedência destes microrganismos seja do canal radicular, sem entretanto, descartar a via hematogênica.

Em 1990, TRONSTAD; KRESHTOOL; BARNETT $^{103}$ confirmaram a presença de microrganismos na superfície apical de um dente portador de lesão periapical crônica, persistente ao tratamento endodôntico convencional. Placas bacterianas constituídas de cocos apresentavam-se firmemente aderidas à superfície apical por um material extracelular, provavelmente polissacarídeo, que além da nutrição, servia de abrigo às influências externas, conseqüentemente contribuindo para a manutenção do processo infeccioso nos tecidos periapicais.

Em dez lesões de origem endodôntica e microscopicamente compatíveis com granulomas periapicais, ARTESE et al. ${ }^{3}, \quad$ em 1991, realizaram 
um estudo empregando microscopia óptica, eletrônica e análise imunocitoquímica com anticorpos monoclonais contra IL-1 $\beta$ e TNF- $\alpha$, com o propósito de detectar e caracterizar células produtoras de IL-1 e TNF nestas lesões. Os achados microscópicos mostraram que somente alguns macrófagos são adaptados para secreção extracelular. Esses macrófagos modificados podem ser os maiores produtores de interleucina nos tecidos. Somente a menor fração dos monócitos/macrófagos (representando cerca de $40 \%$ das células inflamatórias) está em um ativo estado de produção de citocinas. Este fato sugere uma distinta, mas limitada produção dessas citocinas durante inflamação crônica tecidual, podendo explicar a limitada reabsorção presente em granulomas periapicais.

Por meio de métodos clínico, radiográfico e microscópico, LIN et al. ${ }^{57}$, em 1991, analisaram 150 casos considerados insucessos endodônticos, com período de observação variando de 6 meses a 14 anos. Os espécimes constituíam-se de ápices radiculares, acompanhados de tecido perirradicular firmemente aderido, obtidos cirurgicamente. Após fixação em formaldeído a 10\%, os espécimes foram submetidos ao ácido fórmico por 4 semanas para desmineralização e a seguir processados para serem corados por H.E. e Brown e Brenn. Os critérios empregados para análises histopatológica e histobacteriológica foram os seguintes: presença de células inflamatórias crônicas e/ou agudas nos tecidos periapicais; presença de debris necróticos e/ou bactérias nos tecidos periapicais; presença de células inflamatórias agudas e/ou crônicas no canal radicular e presença de debris necróticos e/ou bactérias no canal radicular. Os resultados evidenciaram quantidades variáveis de debris no interior dos canais, e em algumas situações na região periapical, constituídos por raspas de dentina, partículas de cimento endodôntico e tecido inflamado ou necrótico. Observou-se 
também na área periapical, um infiltrado mononuclear predominante, e reabsorção radicular apical freqüentemente associada à inflamação periapical severa. Maciças ou discretas colônias bacterianas, associadas com restos necróticos, apresentavam-se no interior do canal na maioria dos espécimes, e ocasionalmente, na região periapical. Edema e dor, ou fístula, foram frequientemente associados com presença de bactérias no canal radicular e ocasionalmente nos tecidos periapicais. Os autores correlacionaram infecção bacteriana com a maioria dos fracassos endodônticos.

Com o propósito de verificar microrganismos em lesões periapicais persistentes após tratamento endodôntico, WAYMAN et al. ${ }^{107}$, em 1992, estudaram 58 casos de lesões periapicais de origem endodôntica por meio de microscopia óptica e de procedimentos para anaeróbios em diferentes meios de cultura. Foram diagnosticados microscopicamente 41 granulomas, 16 cistos e 1 abscesso dentoalveolar. Das 58 lesões periapicais, 29 tinham comunicação com o meio bucal. Observou-se, crescimento bacteriano em 27 destes casos (93\%); e 11 continham apenas bactérias anaeróbias estritas. Em culturas de oito lesões houve crescimento de apenas uma espécie bacteriana, e nas demais, de 2 a 6 espécies, caracterizando uma infecção mista. As bactérias isoladas com mais frequiência foram: Peptostreptococcus micros, Fusobacterium nucleatum e Bacteroides intermedius. Nas outras 29 lesões, sem comunicação aparente com o meio bucal, 24 casos apresentaram crescimento de microrganismos anaeróbios estritos e facultativos; 13 com crescimento de uma única espécie, e nas demais de 2 a 6 espécies. As bactérias mais comumente isoladas foram: Staphilococcus epidermidis, Propionibacterium acnes, Peptostreptococcus micros e Bacteroides 
gracillis. Concluiu-se que bactérias anaeróbias são importantes para a persistência das lesões crônicas.

Em 1992, WALTON; ARDJAMAND ${ }^{106}$ induziram lesões periapicais em 18 molares de macacos após exposição ao meio bucal por uma semana. Decorridos sete meses, os animais foram sacrificados, e para evitar que bactérias fossem extruídas para a região periapical durante o ato cirúrgico, os espécimes foram removidos através de secções em bloco, incluindo dentes e tecidos circunvizinhos, sendo então processados pelos métodos de rotina, e examinados em microscopia óptica empregando-se a técnica de coloração de Brown e Brenn. Os resultados demonstraram presença marcante de bactérias no interior dos canais, em todos os terços indistintamente; somente em dois casos foram vistos aglomerados bacterianos na altura da constricção apical ou ligeiramente além. Raramente observaram-se bactérias nas lesões periapicais, e quando faziam-se presentes, apareciam como inclusões citoplasmáticas em células fagocitárias, e próximas do forame apical. Em áreas de necrose por liquefação não se constatou presença bacteriana em nenhum espécime.

Em 1992, YAMASAKI et al. ${ }^{112}$ desenvolveram um trabalho experimental em ratos, a fim de mensurar a quantidade de endotoxinas em lesões periapicais induzidas experimentalmente. Bactérias anaeróbias estritas foram isoladas das lesões periapicais numa porcentagem de 10\% nos primeiros dez dias, atingindo $48 \%$ aos 14 dias, porém o número diminuiu gradativamente de 21 a 70 dias (35 a 20\%). O nível de endotoxina nos tecidos periapicais aumentou gradativamente durante o período experimental. Uma correlação positiva foi encontrada entre o conteúdo de endotoxina e bactéria Gram-negativa de 1 a 14 
dias, mas não entre 21 a 70 dias, provavelmente devido ao acúmulo de endotoxina nos tecidos.

A parede celular é um fator determinante do poder patógeno das bactérias Gram-negativas, onde se localiza a estrutura responsável pela ação tóxica, os LPS, parte integrante da bactéria. Os LPS são moléculas de temperatura estável, compostas de polissacarídeos e fosfolipídios. Este componente bacteriano é mais apropriadamente referenciado como LPS. O componente lipídio (lipídio A) determina as propriedades endotóxicas do $\operatorname{LPS}^{80}$.

Os LPS exercem um abundante efeito biológico resultando na amplificação das reações inflamatórias. São antígenos fracos não específicos e pobremente neutralizados pelos anticorpos, além de ativarem o complemento pela via clássica $(\mathrm{C} 1)$ ou alternativa $(\mathrm{C} 3)$, resultando na geração de anafilatoxinas (C3a e C5a), potentes vasodilatadores que facilitam a contração muscular e exercem quimiotaxia para neutrófilos e células mononucleares ${ }^{66}$. Os LPS também induzem as células inflamatórias a produzirem citocinas como interleucina-1, fator de necrose tumoral e linfotoxina, mediadores químicos que participam do processo de reabsorção óssea ${ }^{44,96}$.

A parede celular das bactérias Gram-positivas também está envolvida em processos infecciosos e "flare-ups" dos canais radiculares. São constituídas quimicamente de peptideoglicano e ácido lipoteicóico ${ }^{9}$. A inflamação aguda induzida pelos componentes da parede celular pode evoluir para um processo inflamatório crônico, com um curso prolongado. Peptideoglicano induz secreção de IL-1, TNF $\alpha$ e outras citocinas, como também radicais de oxigênio, 
ácido nítrico e eicosanóides de células como macrófagos, granulócitos e linfócitos. Além disso, ativa o sistema complemento e atua como um estimulador policlonal de linfócitos-B ${ }^{88,49}$. O ácido lipoteicóico induz reabsorção óssea em culturas de tecido ${ }^{62}$.

Por meio de microscopia óptica e imunofluorescência, BOHÓRQUEZ AVILA ${ }^{11}$, em 1994, e posteriormente BOHÓRQUEZ AVILA; ROCHA; CONSOLARO ${ }^{12}$, em 1995, avaliaram 17 dentes humanos com necrose pulpar e portadores de lesões periapicais crônicas. Os diagnósticos revelaram granulomas apicais em sessenta por cento dos casos, e cistos periodontais apicais em quarenta por cento. Observou-se alta incidência de bactérias nos canais radiculares, com predomínio de cocos e bacilos Gram-positivos e Gramnegativos, distribuídas ao longo do lume do canal isoladamente ou em colônias, livres ou aderidas às paredes dentinárias e no interior dos túbulos dentinários. Nas lesões periapicais, apresentavam-se em pequenas quantidades ora isoladas, ora formando colônias, com predomínio de cocos e bacilos Gram-positivos, e localizadas preferencialmente entre o ápice e a lesão periapical, nas imediações do forame apical.

Em um estudo de dez ápices radiculares de dentes tratados endodonticamente e portadores de periapicopatias crônicas, KIRYU; HOSHINO; IWAKU $^{51}$, em 1994, empregando procedimentos padronizados para anaeróbios isolaram bactérias do cemento periapical em duas amostras. Entre anaeróbios estritos e facultativos totalizaram oito espécies bacterianas isoladas. As principais foram: Prevotella oris, Peptostreptococcus products, Fusobacterium russii, Eubacterium D-6, Wolinella sp e Campylobacter sp. O número de bactérias 
recuperadas do cemento foi em torno de $3.0 \times 10^{1}$ a $5.0 \times 10^{1}$ unidades formadoras de colônias (CFUs) por amostra. Um controle experimental revelou ausência de bactérias em cemento intacto de dentes extraídos recentemente, evidenciando ausência de contaminação durante a coleta da amostragem. Os autores concluíram que bactérias podem invadir o cemento via tecido periodontal periapical e desempenhar papéis chaves em periapicopatias crônicas.

Em 1996, BEHREND; CUTLER; GUTMANN ${ }^{8}$ avaliaram o efeito da remoção do "smear layer" sobre a obturação de canal como medida de penetração bacteriana no sentido coroa-ápice. Após a instrumentação, canais de 20 dentes receberam tratamento com EDTA (17\%) e $\mathrm{NaOCl}(5,25 \%)$ para remoção do "smear layer", enquanto em outros 20 canais o "smear layer" permaneceu intacto. Os canais de ambos os grupos foram obturados pela técnica da guta-percha termoplastificada empregando o sistema Thermafil e cimento de Roth. Suas câmaras pulpares foram inoculadas com Proteus vulgaris em "trypticase soy broth", e observações no reservatório apical foram feitas diariamente durante 21 dias para verificar crescimento bacteriano. A freqüência de penetração bacteriana através de canais obturados com "smear layer" intacto foi significantemente maior do que aqueles em que o "smear layer" foi removido. Remoção do "smear layer" aumenta o selamento como evidenciado pelo aumento da resistência à penetração bacteriana.

Em trabalho de revisão da literatura, POTERA ${ }^{79}$, em 1996, observou que nos biofilmes as bactérias encontram-se coagregadas em torno de uma trama perfurada de fibras entrelaçadas de polissacarídeos, conectando cordões de células a uma superfície dura. No interior desse microcosmo, bactérias 
aeróbias e anaeróbias prosperam lado a lado, compartilhando de água e de uma estrutura complexa. Enquanto alguns microrganismos liberam hidrogênio, outros ingerem-no para reduzir dióxido de carbono a metano. A camada de polissacarídeo funciona como um escudo. Estudos têm confirmado que bactérias dos biofilmes são morfológica e metabolicamente distintas daquelas livres, e que qualquer bactéria pode formar biofilme. De encontro a uma superfície dura direciona uma cascata genética que torna os genes específicos a produzir polissacarídeos e outras substâncias necessárias para estabelecer a colônia biofilme. Os biofilmes atingem 50 a $100 \mu \mathrm{m}$ em diâmetros. São resistentes à ação de antibióticos e grandes o suficiente para frustar o sistema imune. A despeito de todas as recentes atividades em pesquisas sobre biofilmes, alguns questionamentos permaneceram sem respostas na revisão da literatura, como: algumas bactérias são mais propensas a formar biofilmes? Quais os biofilmes resistentes a antibióticos? 
3 - PROPOSIÇÃO 


\section{3 - PROPOSIÇÃO}

Considerando a importância dos microrganismos na etiopatogenia das doenças pulpares e periapicais e os questionamentos efetuados a partir da revisão da literatura, propusemo-nos a:

3.1 - Analisar a distribuição das bactérias e colônias bacterianas no lume do canal radicular;

3.2 - Analisar a distribuição das bactérias e colônias bacterianas nas estruturas dos tecidos radiculares mineralizados e em suas superfícies;

3.3 - Analisar a relação destas bactérias com a regularidade das superfícies radiculares internas e externas, especialmente com depósito de dentina reacional e áreas de reabsorções radiculares no canal cementário e superfície apical;

3.4 - Analisar a distribuição das bactérias e colônias bacterianas nos granulomas apicais, isoladamente ou em conjunto com o dente portador. 
4 - MATERIAL E MÉTODOS 


\section{4 - MATERIAL E MÉTODOS}

\section{1 - Amostragem}

\subsection{1 - Obtenção das amostras}

As amostras procederam da Clínica de Cirurgia da Faculdade de Odontologia de Bauru, do Laboratório de Anatomia Patológica do Departamento de Patologia da Faculdade de Odontologia de Bauru, Universidade de São Paulo e de consultórios particulares.

\subsection{2 - Seleção das amostras}

O material deste estudo constituiu-se:

- de 32 raízes dentárias, de pacientes adultos, entre 21 e 72 anos de idade, de ambos os sexos, com lesões periapicais firmemente aderidas a seus ápices;

- de 16 lâminas, em cortes obtidos para fins de diagnóstico microscópico, em cujos laudos histopatológicos constavam conclusões diagnósticas compatíveis com granulomas apicais.

\subsection{3 - Distribuição das amostras}

As amostras foram distribuídas em três grupos: 
Grupo A: 16 dentes com granulomas cortados longitudinalmente

Grupo B: 16 dentes com granulomas cortados transversalmente

Grupo C: 16 granulomas apicais

\subsection{4 - Preparação das amostras}

\subsubsection{1 - Exame macroscópico}

Na macroscopia, exclusivamente para fins de diagnóstico nos laudos anatomopatológicos emitidos e arquivados em cópias no Departamento de Patologia, da Faculdade de Odontologia de Bauru da Universidade de São Paulo (FOB-USP), na análise do dente e do tecido mole aderido registrou-se: a presença de cárie dentária, fratura, restaurações, remanescentes de ligamento periodontal, bem como o grupo dentário. A cor, a consistência, o tamanho e a forma das lesões periapicais crônicas relacionadas foram também descritos. Estes dados não foram relacionados com os aspectos morfológicos apresentados, em função das impossibilidades determinadas pelas variações de formas de obtenção, tipos de cirurgias, dente afetado, ausência das respectivas radiografias e subjetividade dos critérios.

\subsubsection{2 - Fixação}

Os espécimes foram colocados em frascos de vidro individuais, devidamente rotulados, contendo formaldeído a $10 \%$ por um período mínimo de 48 horas. 


\subsubsection{3 - Desmineralização dos espécimes nos grupos A e B}

Após a fixação, os espécimes foram submetidos ao processo de desmineralização, em solução de ácido etilenodiaminotetracético (EDTA) a 5\%,

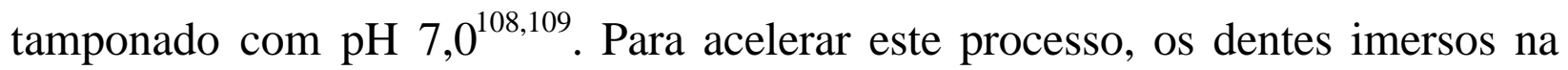
solução de EDTA foram submetidos a ondas eletromagnéticas provenientes de um

forno de microondas ${ }^{86,105}$ apropriado, do Departamento de Patologia da FOB-USP. A solução foi submetida a uma temperatura máxima de $40^{\circ} \mathrm{C}$ e renovada duas vezes por semana. Decorridas cem horas, em média, considerou-se finalizado o processo de desmineralização, quando a raiz dentária apresentava-se com consistência borrachóide, sem resistência ao corte por uma lâmina de microtomia.

\subsubsection{4 - Inclusão}

As peças foram lavadas em água corrente, desidratadas em álcool, diafanizadas em xilol e incluídas em parafina. A seguir montadas em blocos de madeira.

\subsubsection{5 - Microtomia}

Cortes semi-seriados de $5 æ m$ de espessura foram obtidos, utilizando-se um micrótomo marca Leica (RM 2045). Para cada espécime em estudo, imediatamente após a obtenção de um corte que evidenciasse o lume do canal no seu longo eixo, em continuidade com a lesão periapical, realizaram-se mais nove cortes adicionais. 


\subsubsection{6 - Coloração}

Hematoxilina-Eosina de Harris (H.E.)

De cada espécime, selecionaram-se cortes a serem corados por H.E. e avaliados microscopicamente nos seguintes aspectos: morfologia, conteúdo do canal radicular e dos túbulos dentinários, áreas de reabsorções dentinárias e cementárias, presença de lacunas de Howship, diagnóstico da lesão aderida à sua porção apical, características do infiltrado inflamatório, presença de componente epitelial, corpúsculos hialinos de Russel, calcificações distróficas e células pseudoxantomatosas. (Figuras 3, 4, 5, 6, 7, 17, 18, 19, 20, 21 e 36).

Em seguida, as soluções e passos da técnica H.E. estão apresentados tal qual preconizados e registrados nos protocolos técnicos do Departamento de Patologia da FOB-USP.

\subsubsection{1 - Soluções*}

Hematoxilina de Harris ${ }^{100}$

Hematoxilina

Álcool absoluto

Alúmen de potássio

Água destilada

Óxido de mercúrio amarelo
$1 \mathrm{~g}$

$10 \mathrm{ml}$

$20 \mathrm{~g}$

$200 \mathrm{ml}$

$0,5 \mathrm{~g}$

* Dados fornecidos pelo Laboratório de Anatomia Patológica do Departamento de Patologia da Faculdade de Odontologia de Bauru da Universidade de São Paulo (FOB-USP) 
Dissolver a hematoxilina em álcool e o alúmen em água. Misturar as soluções em água aquecida. Adicionar o óxido de mercúrio lentamente reaquecendo a solução até que atinja a coloração roxo-escura. Após o resfriamento filtrar a solução.

Eosina de Lison

Solução A - Eosina

$10 \mathrm{~g}$

Água destilada

$100 \mathrm{ml}$

Solução B - Bicromato de potássio $5 \mathrm{~g}$

Água destilada $\quad 800 \mathrm{ml}$

Solução A + Solução B e acrescentar 100ml de solução saturada de ácido pícrico.

Álcool-Ácido a 3\%

Misturar 3ml de ácido clorídrico em 100ml de álcool etílico 95\%.

\subsubsection{2 - Procedimentos técnicos}

- Desparafinizar e hidratar os cortes de acordo com os métodos convencionais;

- Colocar a lâmina sobre um suporte e cobrir o corte com hematoxilina de Harris por 5 minutos;

- Lavar em água corrente para retirar o excesso de corante;

- Se necessário diferenciar, em ácido clorídrico a $1 \%$ até que saiam "nuvens vermelhas" dos cortes;

- Lavar em água corrente ou em água amoniacal (água com algumas gotas de amoníaco puro); 
- Corar pela eosina por 1 - 5 minutos;

- Lavar em água corrente;

- Desidratar, clarificar e montar.

\subsubsection{7 - Coloração de Brown e Brenn}

Da mesma forma, outros cortes foram selecionados para coloração pela técnica de Brown e Brenn ${ }^{14}$, e avaliados microscopicamente sob os seguintes aspectos: presença, distribuição e localização de bactérias Gram-positivas e Gramnegativas no sistema de canais radiculares, nos túbulos dentinários, nas lacunas de Howship e nas lesões periapicais crônicas (Figuras 3, 4, 5, 6, 7, 17, 18, 19, 20, 21 e 36).

\subsubsection{1 - Soluções*}

Hematoxilina de Harris ${ }^{100}$

Hematoxilina

$1 \mathrm{~g}$

Álcool absoluto

$10 \mathrm{ml}$

Alúmen de potássio

$20 \mathrm{~g}$

Água destilada

$200 \mathrm{ml}$

Óxido de mercúrio amarelo

$0,5 \mathrm{~g}$

Iodo de Gram 1\% (Lugol)

Iodo

$1 \mathrm{~g}$

Iodeto de potássio

$2 \mathrm{~g}$ 
Água destilada 300ml

Dissolver o iodeto de potássio em água destilada. Deixar em repouso em frasco escuro com tampa de vidro e filtrar após 24 horas.

Solução de Galego

Formaldeído

$1 \mathrm{ml}$

Ácido acético

$0,5 \mathrm{ml}$

Água destilada

$50 \mathrm{ml}$

Álcool-Ácido a 3\%

Misturar 3ml de ácido clorídrico em 100ml de álcool etílico $95 \%$.

Cristal Violeta a $1 \%$

Cristal violeta $\quad 1 \mathrm{~g}$

Álcool etílico $\quad 10 \mathrm{ml}$

Ácido carbólico $2 \mathrm{~g}$

Água destilada $\quad 100 \mathrm{ml}$

Observação: repousar por 24 horas e filtrar antes do uso

Éter-Acetona

Éter $\quad 80 \mathrm{ml}$

Acetona $\quad 120 \mathrm{ml}$

Fucsina Básica (estoque)

Fucsina $\quad 0,25 \mathrm{~g}$ 
Água destilada

$100 \mathrm{ml}$

Solução de Trabalho

Solução de estoque

$1 \mathrm{ml}$

Água destilada

$10 \mathrm{ml}$

Deixar em repouso por 24 horas e filtrar antes do uso

Ácido Pícrico-Acetona a 0,1\%

Ácido pícrico

$0,1 \mathrm{~g}$

Acetona

$100 \mathrm{ml}$

Acetona-Xilol

Acetona

$50 \mathrm{ml}$

Xilol

$50 \mathrm{ml}$

\subsubsection{2 - Procedimentos técnicos}

- Desparafinizar e hidratar;

- Corar com hematoxilina de Harris por 5 minutos;

- Passar no diferenciador por 1 minuto;

- Lavar em água corrente por 5 minutos;

- Secar as bordas da lâmina com papel filtro, evitando ressecar o corte. Corar com cristal violeta;

- Escorrer o excesso de corante e cobrir os cortes com lugol por 1 minuto;

- Escorrer o excesso da solução, diferenciar os cortes éter + acetona até não ter mais corante; 
- Lavar as lâminas rapidamente em água destilada e secar com papel de filtro os cortes;

- Corar com solução de trabalho por 3 minutos;

- Escorrer o excesso do corante, lavar rapidamente com água destilada e secar as lâminas sem secar os cortes;

- Diferenciar na solução de galego por 3 minutos;

- Lavar as lâminas em água destilada e secá-las sem secar os cortes. Mergulhar em seguida em acetona por 10 segundos a 1 minuto;

- Diferenciar em ácido pícrico + acetona até que o tecido tome coloração róseo amarelada por 10 segundos;

- Esse passo, o mais crítico, deve ser realizado no sentido de retirar a maior parte de fucsina;

- Imergir 3 vezes em acetona pura sob leve agitação, para remover completamente o ácido pícrico;

- Lavar em mistura partes iguais acetona + xilol por 15 segundos;

- Clarear em xilol 10 banhos;

- Montar os cortes em lâminas.

\subsection{5 - Análise microscópica}

A leitura das lâminas foi realizada com auxílio de um microscópio Olympus CBA binocular, e os resultados foram distribuídos em tabelas previamente elaboradas, representadas pelas Figuras 3, 4, 5, 6, 7, 17, 18, 19, 20, 21 e 36, nas quais tem-se os fenomenos e aspectos morfológicos possíveis de registros. 
Os aspectos morfológicos foram agrupados de acordo com o local:

- do canal radicular dentinário;

- da dentina;

- do canal radicular cementário;

- da superfície apical;

- dos granulomas apicais.

\subsection{6 - Fotomicrografias}

As lâminas foram fotomicrografadas em aparelho Zeiss do Departamento de Patologia da Faculdade de Odontologia de Bauru (FOB-USP) utilizando-se de filme Elite Gold-Kodak, ASA 100. 

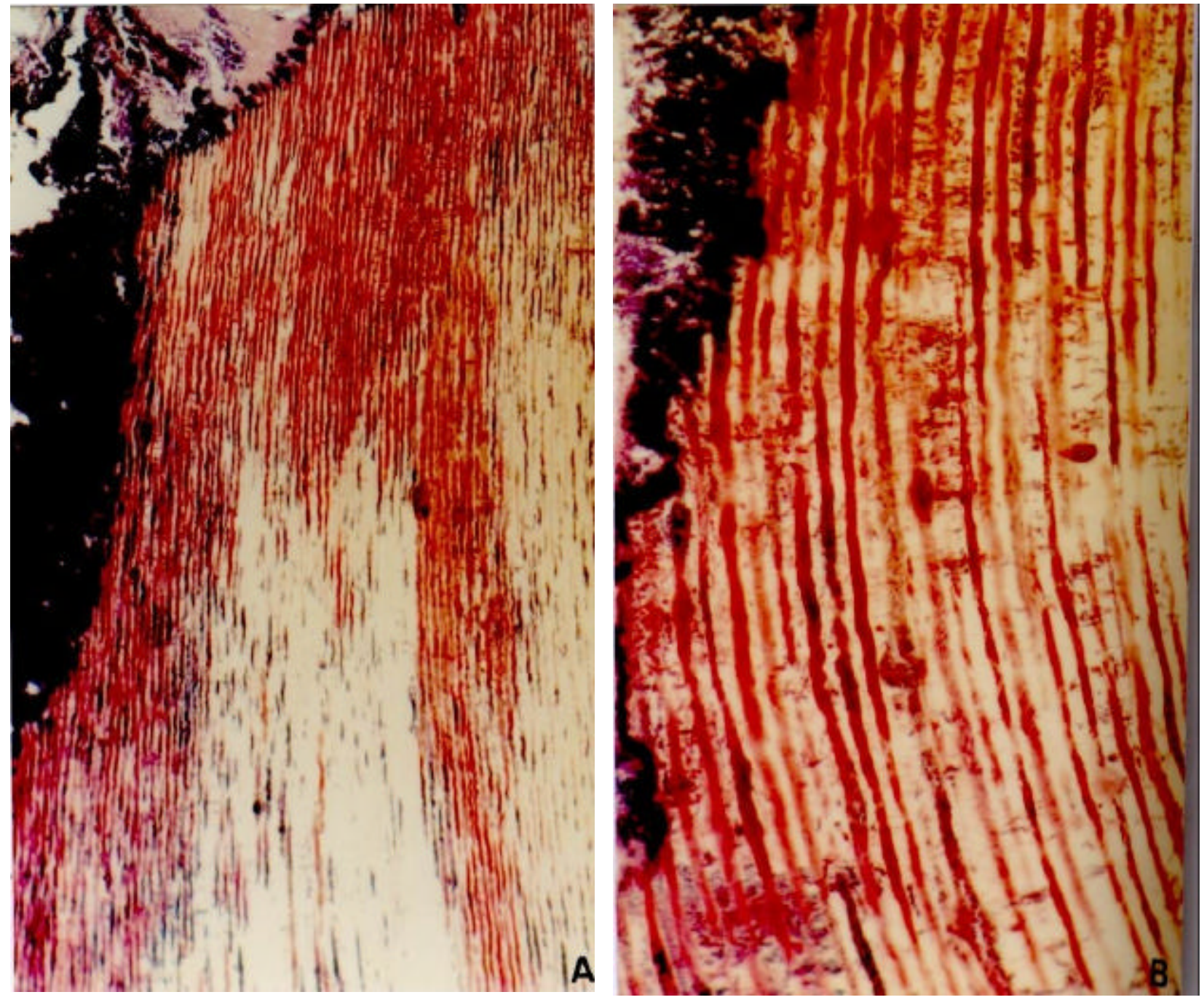

FIGURA 1 - Aspectos microscópicos da invasão dentinária de bactérias Grampositivas e Gram-negativas na cárie dentária, utilizados como controle positivo da técnica de coloração de Brown e Brenn. 

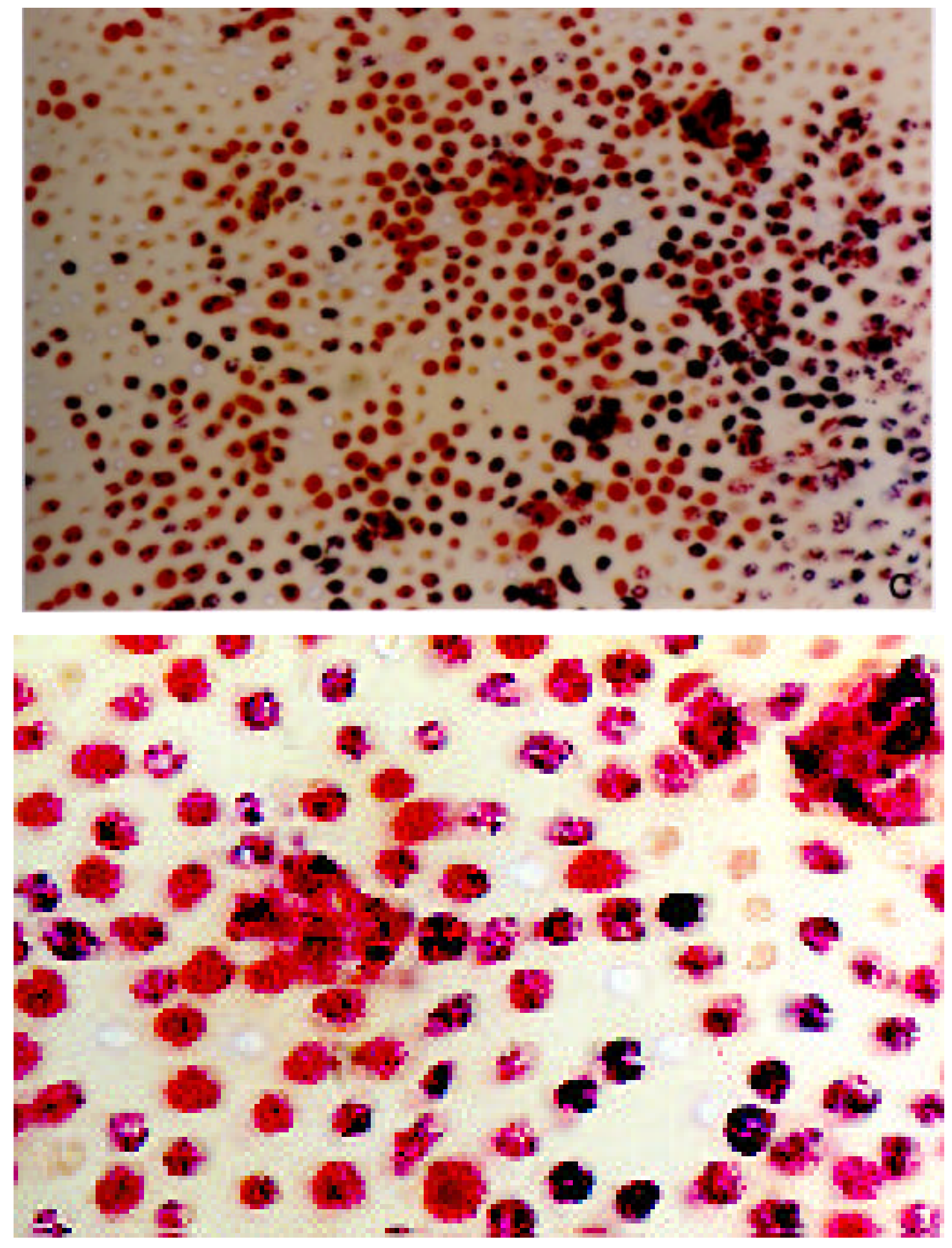

As bactérias Gram-positivas geralmente estão individualizadas, as Gram-negativas geralmente apresentam-se em forma de borrão avermelhado; em cortes transversais dos túbulos podem também estar individualizadas. (Aumento original: $\mathrm{A}=10 \mathrm{X}, \mathrm{B}=160 \mathrm{X}, \mathrm{C}=40 \mathrm{X}, \mathrm{D}=400 \mathrm{X}$; Brown e Brenn) 
5 - RESULTADOS 


\section{5 - RESULTADOS}

Os dados obtidos serão apresentados levando-se em consideração os aspectos morfológicos do canal radicular e de seu conteúdo; a distribuição das bactérias no lume do canal, nos túbulos dentinários e nas lesões periapicais crônicas, a partir da análise microscópica de cortes de tecidos corados pela técnica da hematoxilina-eosina de Harris e pela coloração de Brown e Brenn. Analisaram-se 32 raízes portadoras de necrose pulpar, acompanhadas de granulomas apicais (cortes longitudinais e transversais) e 16 granulomas apicais isolados, distribuídos nos três grupos experimentais (A, B e C).

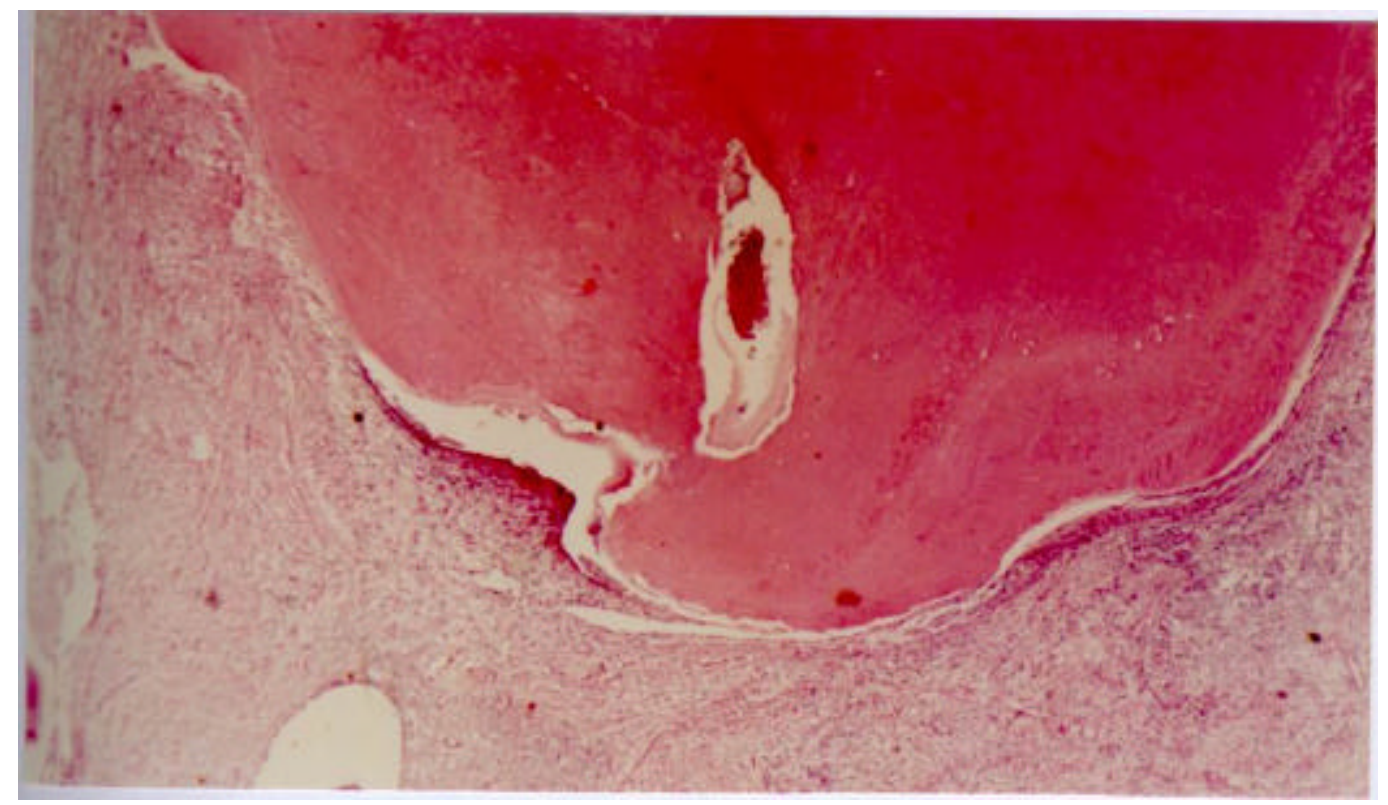

FIGURA 2 - Aspectos microscópicos do terço apical mostrando a inter-relação com o granuloma apical e a íntima associação do canal radicular e sua abertura correspondente ao forame apical. Destaca-se ainda a presença de colônias bacterianas no lume do canal radicular, além de irregularidades nas paredes internas do canal e nas superfícies externas apicais. (Aumento original: 10X, H.E.) 


\section{1 - Grupo A - Dentes com granulomas apicais cortados longitudinalmente}

Os cortes neste grupo mostravam uma distribuição e inter-relação tecidual bem característica com o canal e granuloma, como se vê na Figura 8 .

\subsection{1 - Observações relativas ao canal radicular (Figura 3)}

O canal radicular, no seu terço apical, foi observado em toda a extensão de suas paredes e limites, na maioria dos espécimes. Em cinco espécimes, a incidência do corte e a irregularidade morfológica do canal radicular impediram a visualização completa e panorâmica.

As paredes dentinárias apresentaram-se com depósitos irregulares de dentina reacional, caracterizados por espessuras variadas e soluções de continuidade. Em três espécimes, nódulos pulpares de tamanhos variados foram observados, próximos às paredes do canal, e em dois espécimes, aderidos à dentina reacional.

Os depósitos de dentina reacional, como também as áreas de reabsorções cementárias e/ou dentinárias nas paredes internas do canal radicular proporcionaram mudanças morfológicas importantes em suas superfícies, o suficiente para impedir uma visualização nítida do limite CDC na maioria dos espécimes. Em apenas dois espécimes este limite pôde ser visto nitidamente.

Dos 16 espécimes analisados, a abertura correspondente ao forame apical, foi observada em 14. Considerando as limitações de uma visão 
bidimensional, esta situou-se no extremo apical da raiz em oito situações e nas demais ocupou uma posição lateral.

Ladeando o forame apical, observaram-se em 7 espécimes duas a três foraminas, constituindo o delta apical, cujas extensões estavam incluídas quase que na totalidade no interior do cemento apical.

Nos 16 espécimes analisados, havia conteúdo pulpar detectável microscopicamente. Todas as amostras foram positivas para a presença de colônias bacterianas, que coradas pela técnica de Brown e Brenn, permitiram-nos concluir ser alta a freqüência de cocos e bacilos Gram-positivos e Gram-negativos, e menos freqüentes os morfotipos espiralados. Além do componente bacteriano, observaram-se na maioria dos espécimes, restos teciduais necrosados. E em sete espécimes, células de contornos prismáticos, com inclusões citoplasmáticas basofílicas foram identificadas como células vegetais, o que denota a presença de restos alimentares. Observou-se também, em quatro espécimes, próximo à abertura correspondente ao forame apical, presença de um infiltrado inflamatório desorganizado, do tipo neutrofílico.

\subsection{2 - Observações relativas à dentina radicular apical (Figura 4)}

Na maioria dos espécimes, observou-se uma dentina desorganizada, com seus túbulos dentinários distribuídos irregularmente. A incidência do corte $\mathrm{e}$ as irregularidades em seus trajetos impediram uma visualização completa dos túbulos ao longo de suas extensões (Figura 12). 
Em cinco espécimes pôde-se observar, com nitidez, na porção final da dentina radicular apical, obliterações dos túbulos dentinários ora por depósitos de dentina reacional, ou por cemento projetado sobre a dentina no nível da junção cemento-dentina, como se pode ver nas Figuras 8 e 10.

A densidade bacteriana intratubular foi considerada leve na maioria dos espécimes. Tanto a quantidade de túbulos infectados por área quanto o número de microrganismos foram considerados pequenos, em relação aos outros terços radiculares. Isto contribuiu para que os túbulos dentinários se mantivessem preservados em todos os espécimes.

Quantitativamente, observou-se uma predominância de bactérias Gram-negativas. Estas apresentavam-se em forma de borrões avermelhados, dificultando o delineamento de seus corpos. $\mathrm{O}$ oposto foi observado em relação às bactérias Gram-positivas, com seus corpos bem definidos e distintos. Em um espécime notou-se somente presença de bactérias Gram-negativas no interior dos túbulos dentinários, considerando o plano de corte.

\subsection{3 - Observações relativas ao canal cementário (Figura 5)}

$\mathrm{Na}$ maioria das amostras, as paredes do canal cementário apresentaram-se com áreas de reabsorções em graus variados, provocando alterações significantes em sua forma anatômica (Figuras 8, 9 e 10). Em um espécime o cemento foi totalmente reabsorvido, acarretando seu desaparecimento (Figura 39). 
Em dois espécimes, o cemento estendeu-se até a parede interna da dentina por uma curta distância. Observaram-se que os túbulos da camada dentinária subjacente encontravam-se livres de bactérias.

Em todos os espécimes passíveis de análise microscópica, foram observadas colônias bacterianas no canal cementário. Encontravam-se livres ou aderidas às paredes cementárias, principalmente nas lacunas de Howship. Em sete espécimes, estas foram encontradas também no interior de cementoplastos.

Em dois espécimes do grupo, próximo à abertura correspondente ao forame apical, notou-se uma quantidade exagerada de colônias bacterianas superpostas, de aspectos morfológicos variados, constituindo-se em um verdadeiro "plug bacteriano" apical (Figuras 9, 10, 12).

\subsection{4 - Observações relativas à superfície apical (Figura 6)}

A superfície apical apresentou-se irregular em todos os espécimes analisados. Estas alterações morfológicas estavam relacionadas na maioria dos espécimes a áreas de reabsorções cementárias. Em cinco espécimes, as lacunas de reabsorções se fizeram presentes na camada dentinária subjacente.

O cemento celular, característico da região, apresentou-se na maioria dos espécimes com suas lacunas ora vazias, ora contidas por restos celulares e/ou colônias bacterianas. Ressalta-se ainda a variabilidade em sua espessura nos diferentes espécimes, relacionadas à idade cronológica do dente, grupo dentário e fenômenos patológicos. 
Em dez espécimes, observaram-se colônias bacterianas aderidas à superfície apical; localizadas na maioria dos espécimes, nas superfícies irregulares próximas às aberturas correspondentes ao forame apical, foraminas e túbulos dentinários, quando expostos. De aspectos morfológicos variados, pôde-se observar a presença de cocos, bacilos e espirilos, com predominância absoluta das bactérias Gram-negativas. Em alguns espécimes, as bactérias apresentavam-se como se estivessem revestindo parte da superfície apical, como se pode ver nas Figuras 13, 14 e 15.

\subsection{5 - Observações relativas aos granulomas apicais (Figura 7)}

A maioria dos espécimes apresentava um granuloma bem típico, formado por tecido ricamente vascularizado envolvendo o ápice radicular. Próximo ao ápice, observaram-se em alguns espécimes, infiltrado inflamatório crônico intenso, constituído por linfócitos, plasmócitos, macrófagos e ainda neutrófilos. Os neutrófilos encontravam-se concentrados especialmente em nível do forame apical e em torno de restos epiteliais em proliferação. Nesta região, observou-se com certa freqüência formação de microabscessos, oriundos da interação neutrófilos e antígenos bacterianos que se difundem do canal. No foco exsudativo, encontravam-se com certa frequiência os corpúsculos hialinos de Russel, elementos comuns nas inflamações crônicas, apresentando-se ora livres, ora no interior dos plasmócitos e as células espumosas ou pseudoxantomatosas. Em dois espécimes notou-se a presença de células gigantes multinucleadas nas proximidades dos depósitos de cristais de colesterol. Nos espécimes onde foram identificados restos epiteliais de Malassez, estes apresentavam-se sob a forma de 
ilhotas de células cubóides ou pequenos cordões direcionados para o centro da lesão.

Freqüentemente, observaram-se na maioria dos espécimes, bactérias isoladas ou em colônias na intimidade do tecido granulomatoso (Figuras 8, 13, 14 e 15). Quando isoladas, apresentavam-se nos espaços extracelulares e nos vacúolos de macrófagos. Também foram notadas colônias bacterianas ora relacionadas ao ápice, ora ocupando a parte central da lesão. Em um espécime, estas encontravamse posicionadas perifericamente, sendo morfologicamente identificadas como cocos e bacilos Gram-positivos e Gram-negativos. 


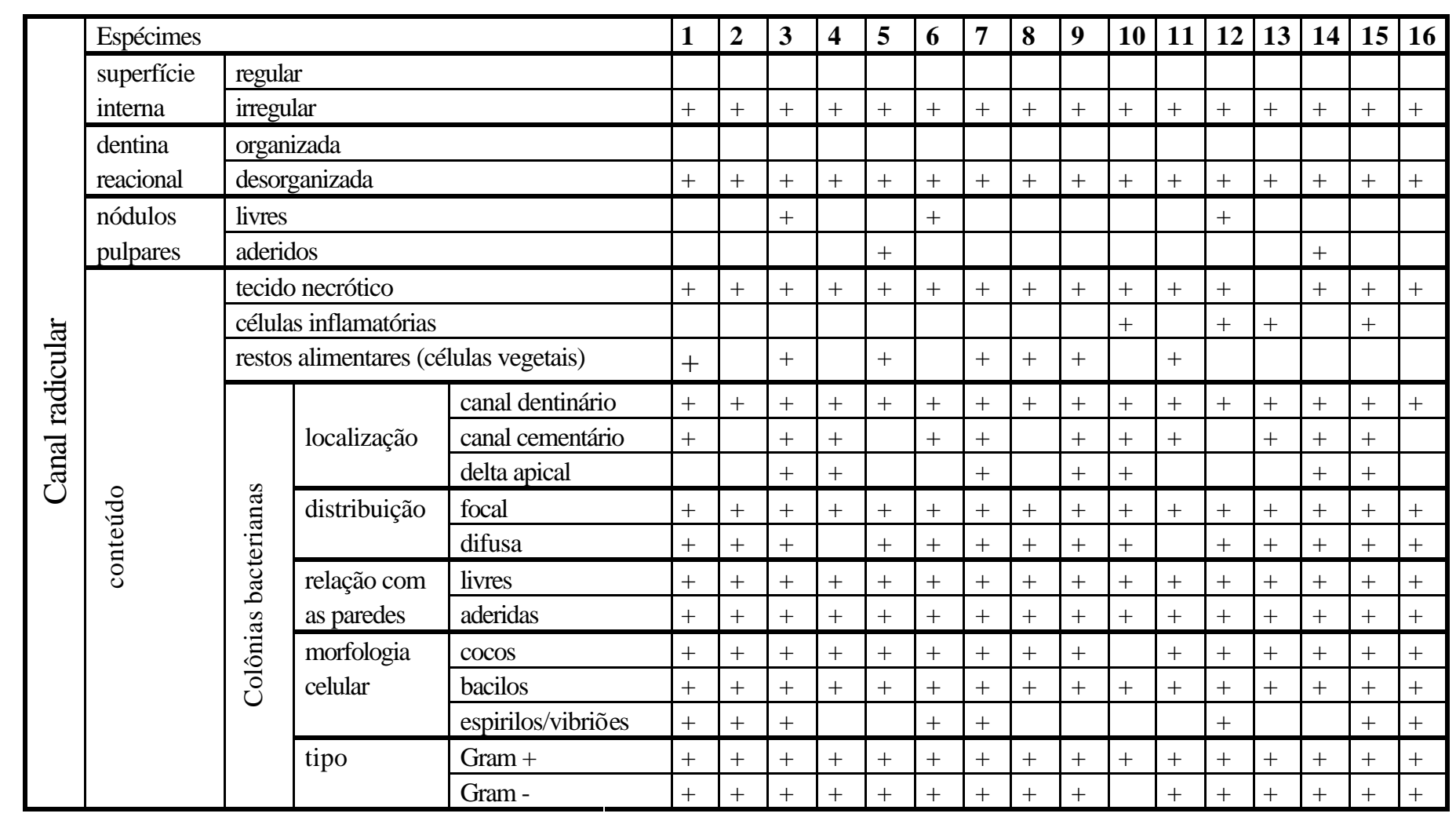

FIGURA 3 - GRUPO A: Distribuição dos achados microscópicos morfológicos do canal radicular e seu conteúdo, em cortes longitudinais, corados pelas técnicas da hematoxilina-eosina e de Brown e Brenn 


\begin{tabular}{|c|c|c|c|c|c|c|c|c|c|c|c|c|c|c|c|c|c|c|c|}
\hline \multirow{5}{*}{ 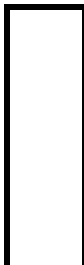 } & \multicolumn{3}{|l|}{ Espécimes } & 1 & 2 & 3 & 4 & 5 & 6 & 7 & 8 & 9 & 10 & 11 & 12 & 13 & 14 & 15 & 16 \\
\hline & \multirow{4}{*}{$\begin{array}{l}\text { túbulos } \\
\text { dentinários }\end{array}$} & \multicolumn{2}{|l|}{ preservados } & + & + & + & + & + & + & + & + & + & + & + & + & + & + & + & + \\
\hline & & \multicolumn{2}{|l|}{ dilatados } & & & & & & & & & & & & & & & & \\
\hline & & \multicolumn{2}{|l|}{ varicosos } & & & & & & & & & & & & & & & & \\
\hline & & \multicolumn{2}{|c|}{ focos de liquefação } & & & & & & & & & & & & & & & & \\
\hline & \multirow{13}{*}{ 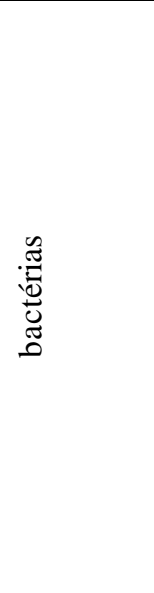 } & \multicolumn{2}{|l|}{ presentes } & + & + & + & + & + & + & + & + & + & + & + & & + & + & + & + \\
\hline & & \multicolumn{2}{|l|}{ ausentes } & & & & & & & & & & & & + & & & & \\
\hline & & \multirow{3}{*}{$\begin{array}{l}\text { morfologia } \\
\text { celular }\end{array}$} & $\operatorname{cocos}$ & + & + & + & + & + & + & + & + & + & & + & & + & + & + & + \\
\hline 寻 & & & bacilos & + & + & + & + & + & + & + & + & + & + & + & & + & + & + & + \\
\hline$\frac{\Phi}{0}$ & & & espirilos/vibriões & & & & & & & & & & & & & & & & \\
\hline & & \multirow[t]{2}{*}{ tipo } & Gram + & + & + & + & + & + & + & + & + & + & + & + & & + & + & + & + \\
\hline & & & Gram - & + & + & + & + & + & + & + & + & + & & + & & + & + & + & + \\
\hline & & \multirow{3}{*}{$\begin{array}{l}\text { densidade } \\
\text { intratubular }\end{array}$} & leve & & + & & + & + & + & + & + & + & + & + & & & + & + & \\
\hline & & & moderada & + & & + & & & & & & & & & & & & & + \\
\hline & & & intensa & & & & & & & & & & & & & + & + & & \\
\hline & & \multirow{3}{*}{$\begin{array}{l}\text { localização/ } \\
\text { distribuição }\end{array}$} & 1/3 pulpar & & + & & & & + & & + & & & + & & & . & + & + \\
\hline & & & $1 / 3$ médio & + & & & + & + & & + & & + & + & & & & + & & \\
\hline & & & $1 / 3$ superficial & & & + & & & & & & & & & & + & & & \\
\hline
\end{tabular}

FIGURA 4 - GRUPO A: Distribuição dos achados microscópicos morfológicos das bactérias Grampositivas e Gram-negativas nos túbulos dentinários, em cortes longitudinais, corados pelas técnicas da hematoxilina-eosina e de Brown e Brenn 


\begin{tabular}{|c|c|c|c|c|c|c|c|c|c|c|c|c|c|c|c|c|c|c|c|c|}
\hline \multirow{17}{*}{ 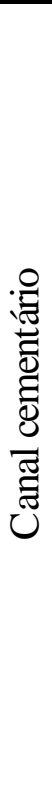 } & & & & Espécimes & 1 & 2 & 3 & 4 & 5 & 6 & 7 & 8 & 9 & 10 & 11 & 12 & 13 & 14 & 15 & 16 \\
\hline & \multirow{4}{*}{ morfologia } & \multicolumn{3}{|l|}{ preservada } & & & & & & & & & & & & & & & & \\
\hline & & \multirow{3}{*}{ alterada } & \multicolumn{2}{|c|}{ por hipercementose } & & & + & & & & & & & & & & & + & & \\
\hline & & & \multirow{2}{*}{$\begin{array}{l}\text { por reab- } \\
\text { sorção }\end{array}$} & c/ clastos & & & & & & & & & + & & & & + & & & \\
\hline & & & & $\mathrm{s} /$ clastos & + & & + & + & & + & + & & & + & + & & & + & + & \\
\hline & \multirow{12}{*}{ 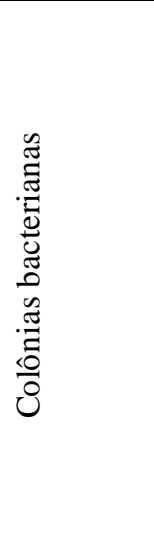 } & \multicolumn{3}{|l|}{ presentes } & + & & + & + & & + & + & & + & + & + & & + & + & + & \\
\hline & & \multicolumn{3}{|l|}{ ausentes } & & & & & & & & & & & & & & & & \\
\hline & & \multirow{3}{*}{$\begin{array}{l}\text { morfologia } \\
\text { celular }\end{array}$} & \multicolumn{2}{|l|}{$\operatorname{cocos}$} & + & & + & + & & + & + & & + & & + & & + & + & + & \\
\hline & & & \multirow{2}{*}{\multicolumn{2}{|c|}{$\begin{array}{l}\text { bacilos } \\
\text { espirilos/vibriões }\end{array}$}} & + & & + & + & & + & + & & + & + & + & & + & + & + & \\
\hline & & & & & + & & + & & & & + & & & & & & & & & \\
\hline & & \multirow[t]{2}{*}{ tipo } & \multicolumn{2}{|c|}{ Gram + } & + & & + & + & & + & & & + & + & + & & + & + & + & \\
\hline & & & \multicolumn{2}{|l|}{ Gram - } & + & & + & + & & + & & & + & & + & & + & + & + & \\
\hline & & \multirow{5}{*}{ localização } & \multicolumn{2}{|c|}{ no lume } & + & & + & & & + & + & & + & & + & & & + & + & \\
\hline & & & \multicolumn{2}{|c|}{ nas lacunas de Howship } & + & & + & + & & + & + & & + & + & + & & & + & + & \\
\hline & & & \multicolumn{2}{|c|}{ no cemento } & + & & + & & & + & + & & + & + & + & & + & + & + & \\
\hline & & & \multirow{2}{*}{\multicolumn{2}{|c|}{$\begin{array}{l}\text { na dentina } \\
\text { no cementoplasto }\end{array}$}} & + & & + & & & & + & & & & + & & & & & \\
\hline & & & & & + & & + & & & & + & & + & & + & & & + & + & \\
\hline
\end{tabular}

FIGURA 5 - GRUPO A: Distribuição dos achados microscópicos morfológicos das bactérias Grampositivas e Gram-negativas no canal cementário, em cortes longitudinais, corados pelas técnicas da hematoxilina-eosina e de Brown e Brenn 


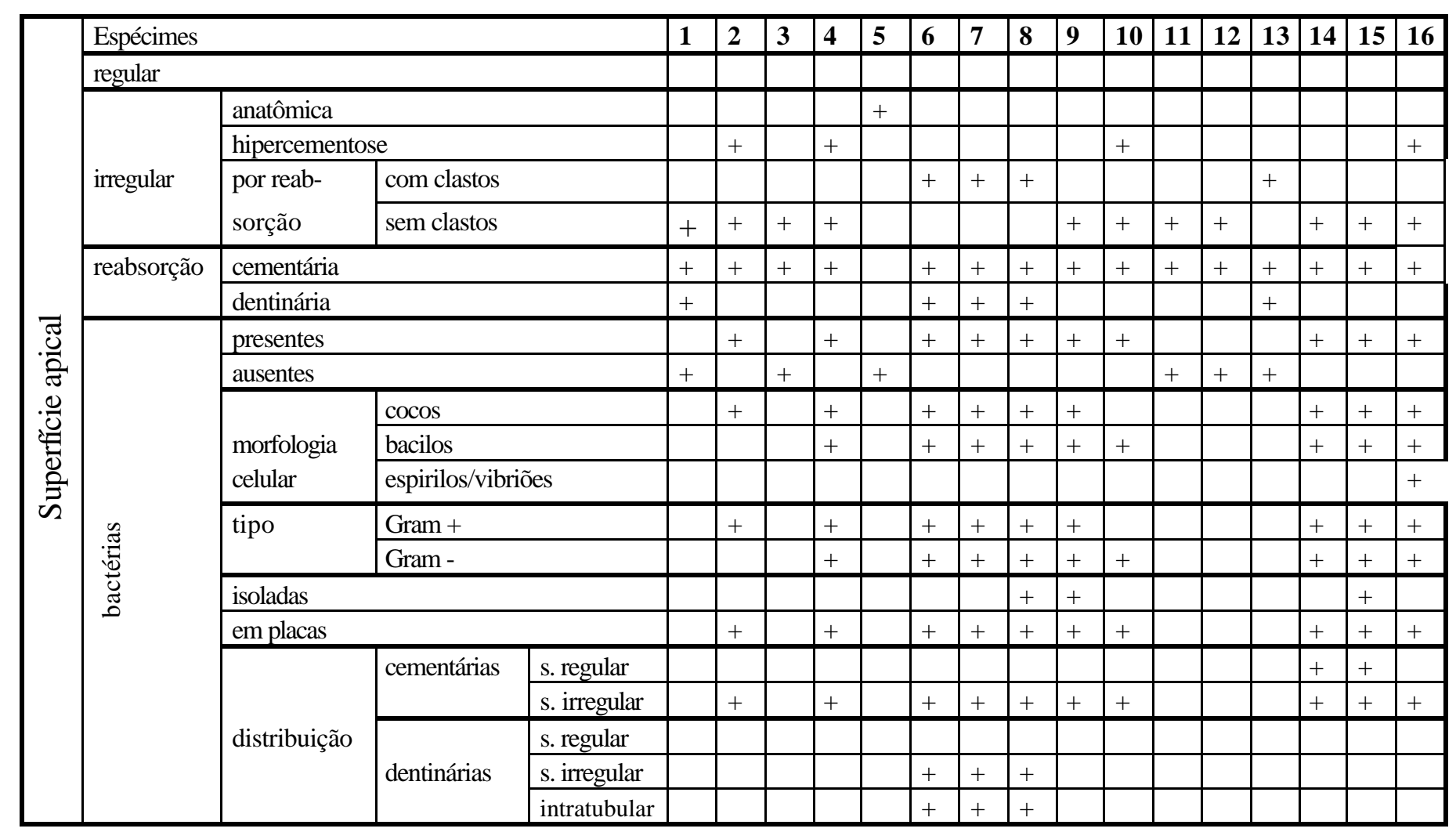

FIGURA 6 - GRUPO A: Distribuição dos achados microscópicos morfológicos da superfície apical e das bactérias Gram-positivas e Gram-negativas, em cortes longitudinais, corados pelas técnicas da hematoxilina-eosina e de Brown e Brenn 


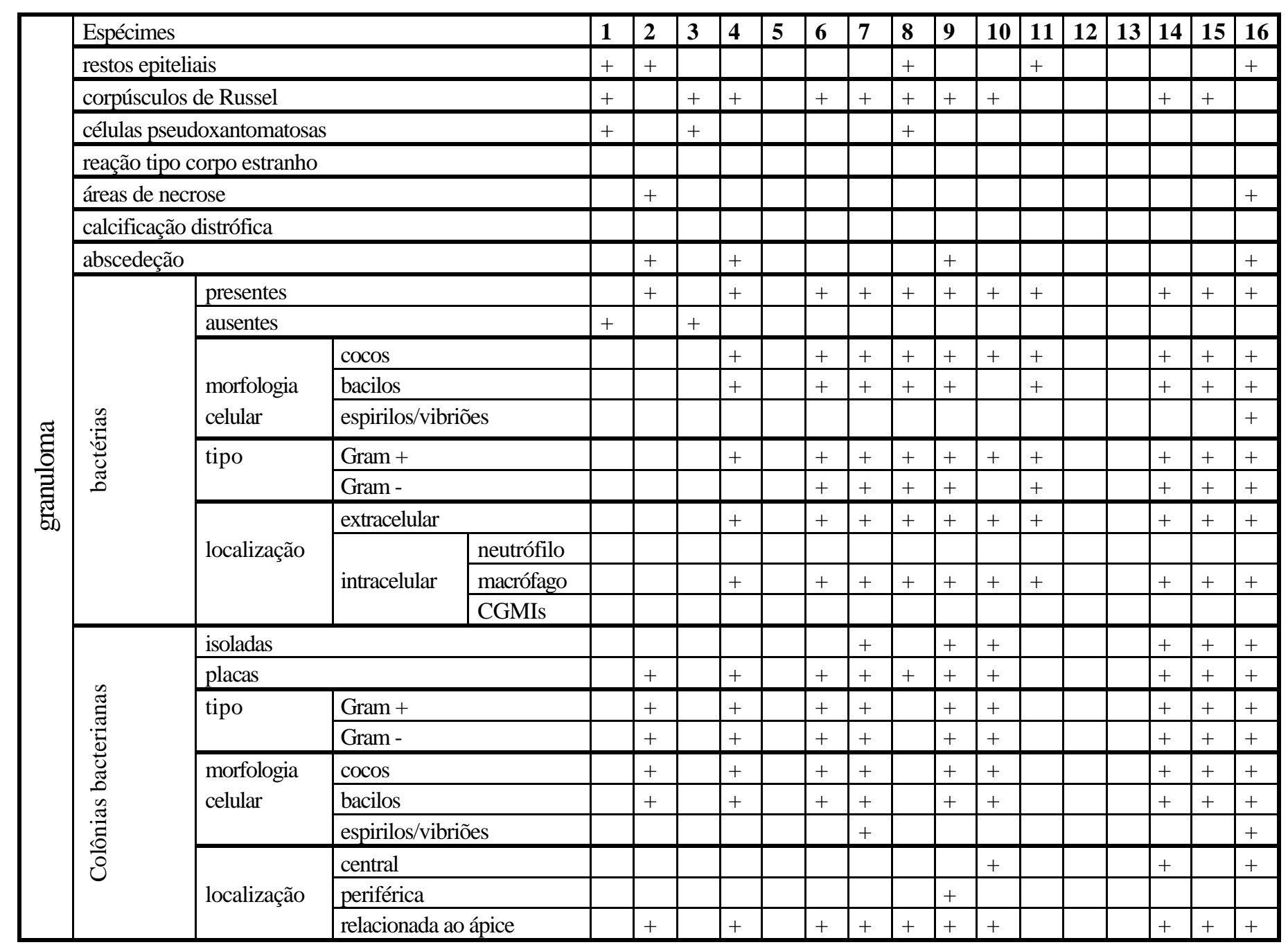

FIGURA 7 - GRUPO A: Distribuição dos achados microscópicos morfológicos das bactérias Grampositivas e Gram-negativas nos granulomas apicais, em cortes longitudinais, corados pelas técnicas da hematoxilina-eosina e de Brown e Brenn 

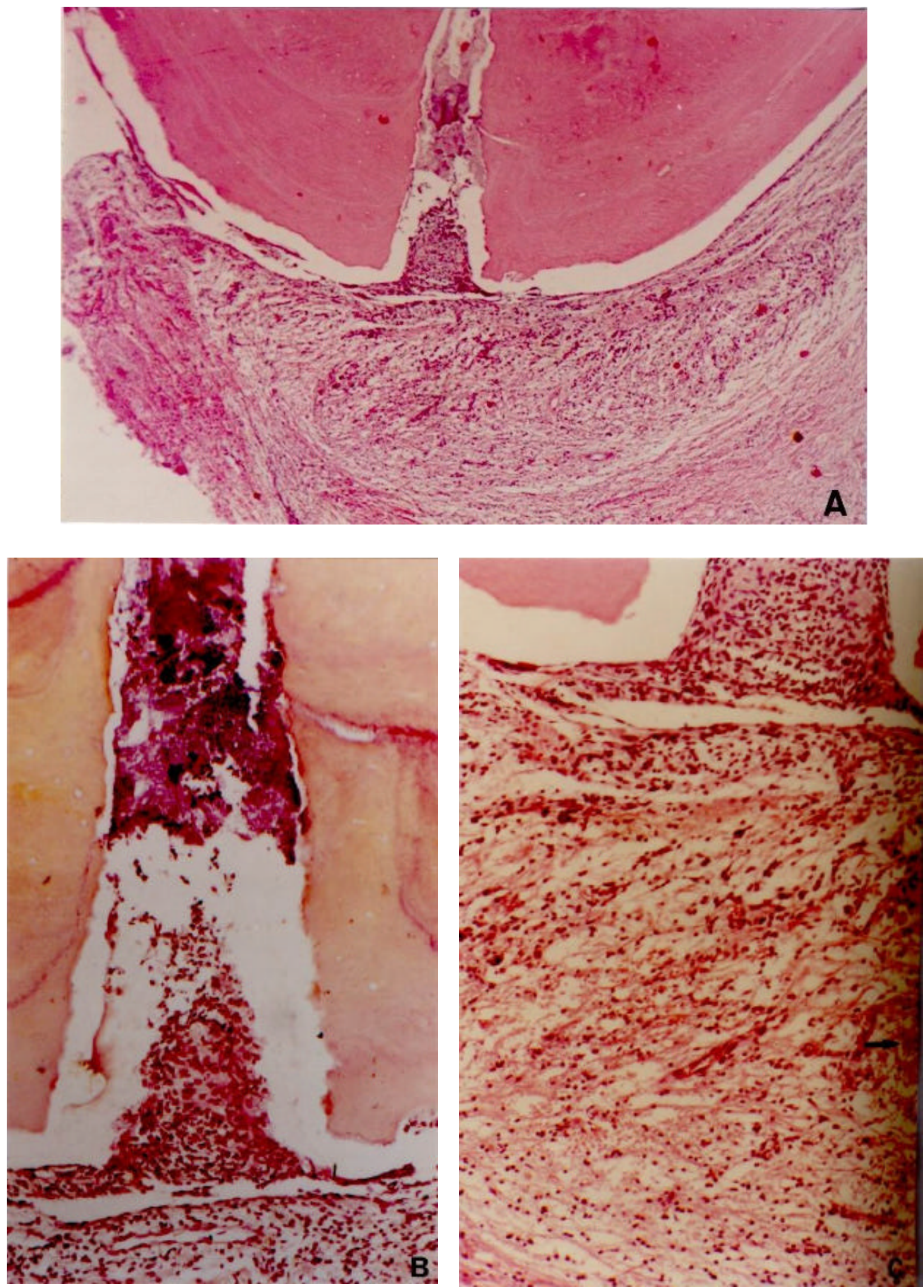

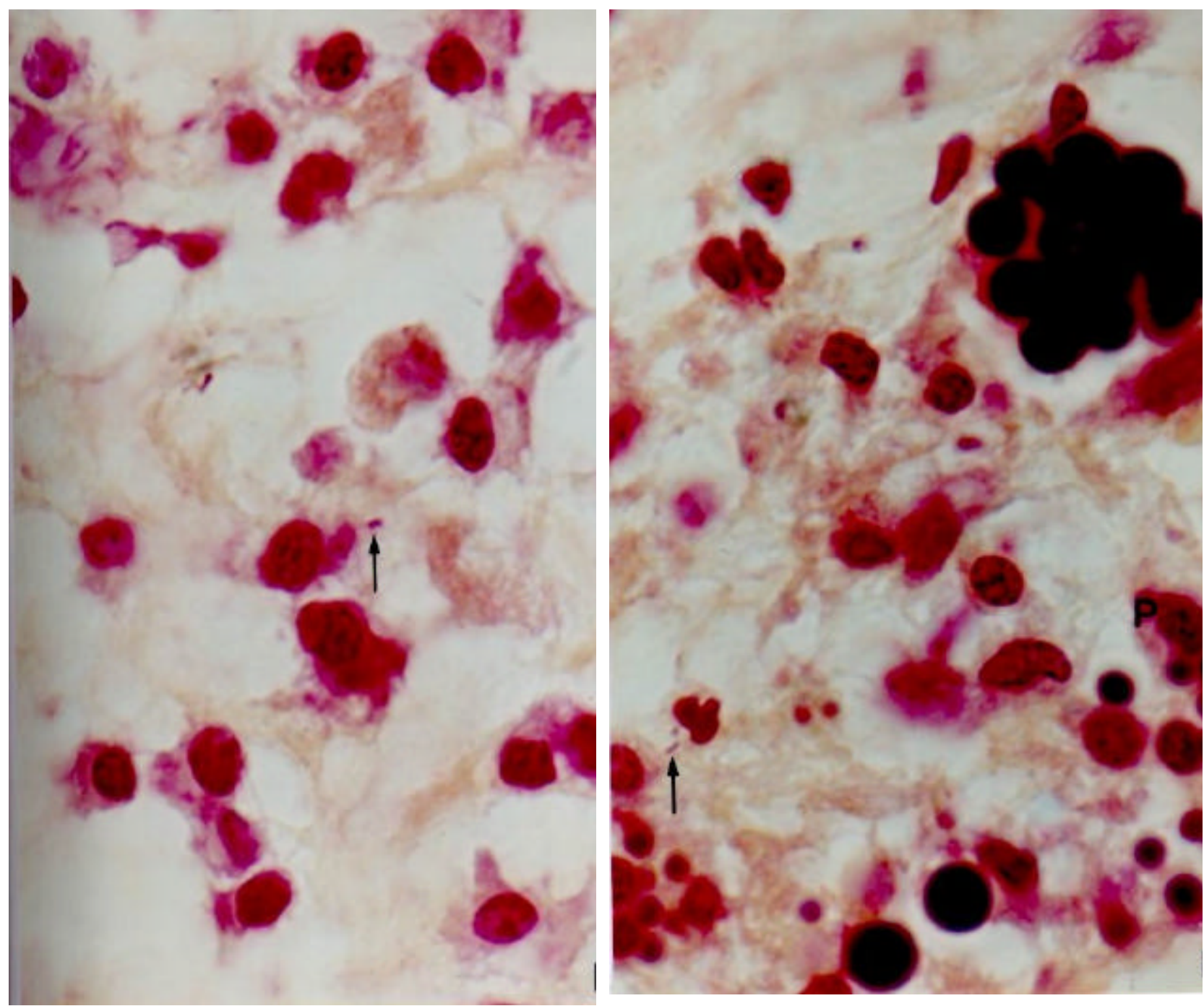

FIGURA 8 - Terço apical de dente com necrose pulpar e granuloma apical, microscopicamente observado, em cortes longitudinais, corados em H.E. e Brown e Brenn. Destacam-se as irregularidades do canal cementário e da superfície apical, além das colônias bacterianas Gram-positivas e Gram-negativas intracanal. No "coto periodontal", em B, observa-se grande número de neutrófilos atraídos pelas bactérias. Em $\mathrm{C}$, nota-se grande número de células mononucleares e corpúsculo hialino de Russel (seta), no granuloma. Em D e E, aspectos morfológicos celulares do granuloma apical. Os macrófagos apresentam corpos bacterianos em vacúolos intracelulares (setas). Os plasmócitos (P) são numerosos, e com frequiência são detectados corpúsculos hialinos de Russel isolados ou aglomerados em forma de cacho de uvas. (Aumento original: $\mathrm{A}=$ 10X, H.E.; $\mathrm{B}=$ 40X, Brown e Brenn; $\mathrm{C}=40 \mathrm{X}$, H.E.; D e $\mathrm{E}=400 \mathrm{X}$, Brown e Brenn) 

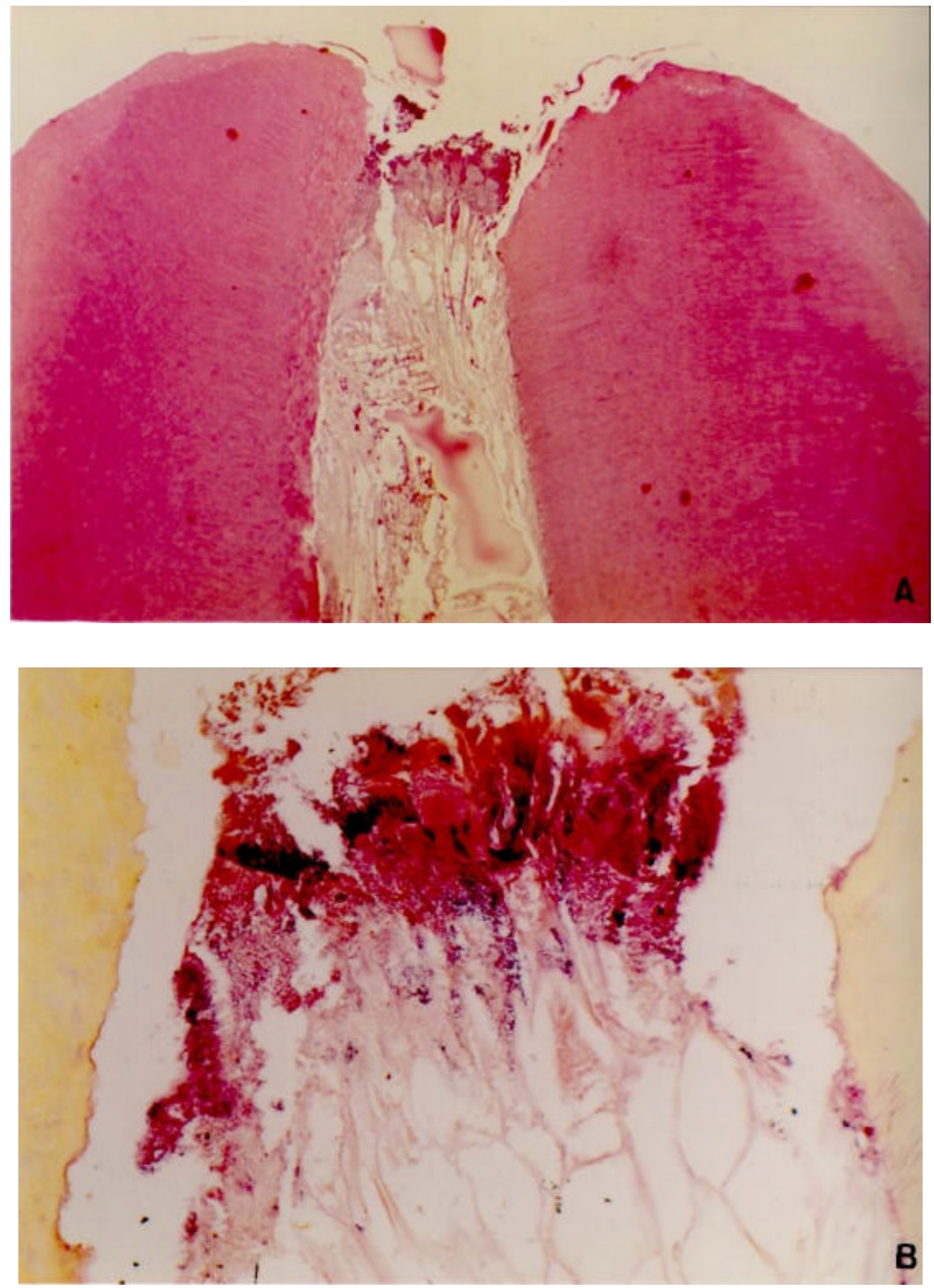

FIGURA 9 - Terço apical de dente com necrose pulpar e granuloma apical, com "plug bacteriano" constituído por colônias bacterianas Grampositivas e Gram-negativas. 

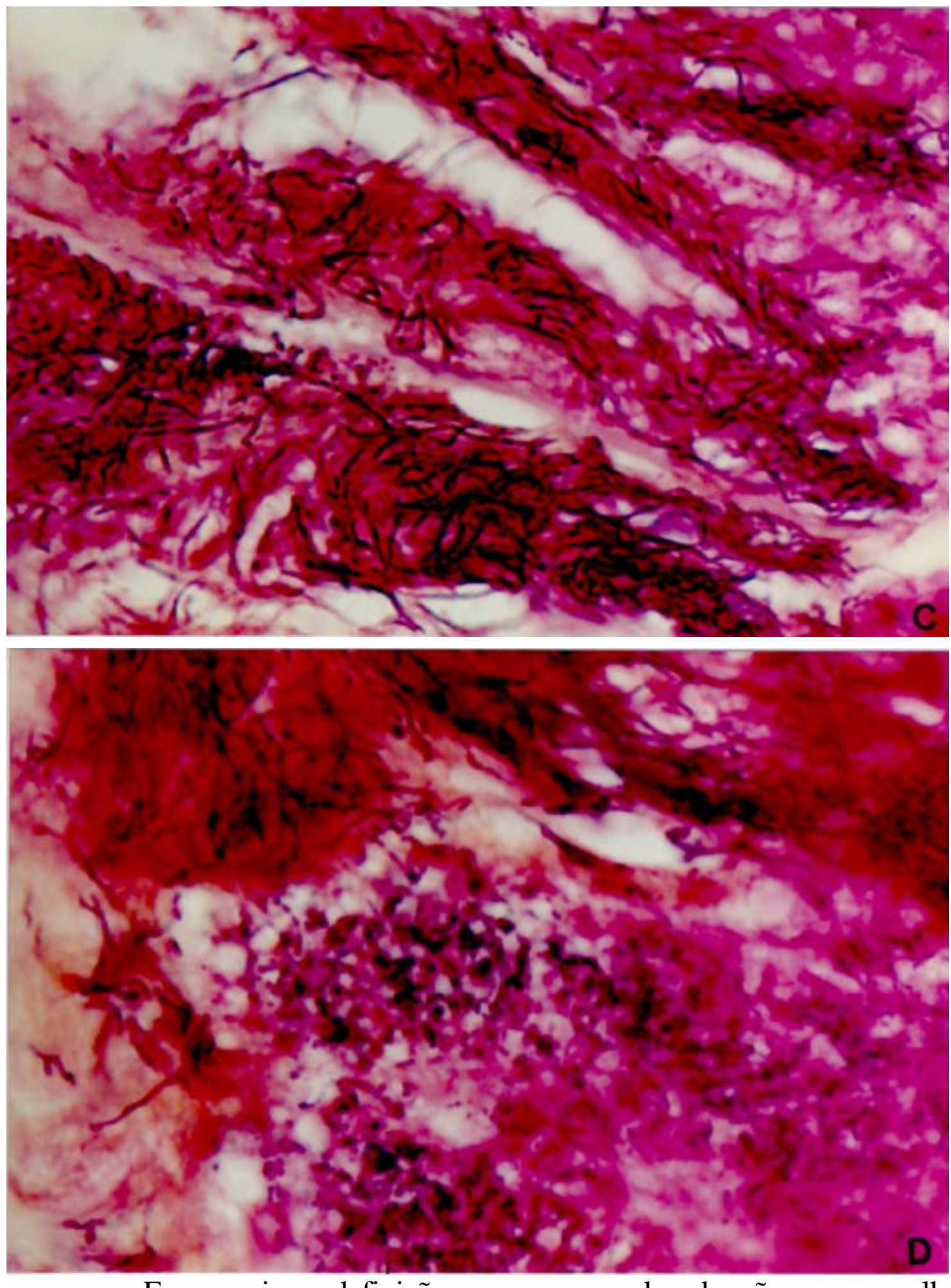

Em maior definição, presença de borrões avermelhados correspondentes às colônias Gram-negativas, associadas a cocos e bacilos Grampositivos. No canal cementário e superfície apical (A e B), observa-se a irregularidade das paredes dentinárias e cementárias. (Aumento original: $\mathrm{A}=10 \mathrm{X}$, H.E.; $B=40 X, C$ e $D=400 X$, Brown e Brenn) 

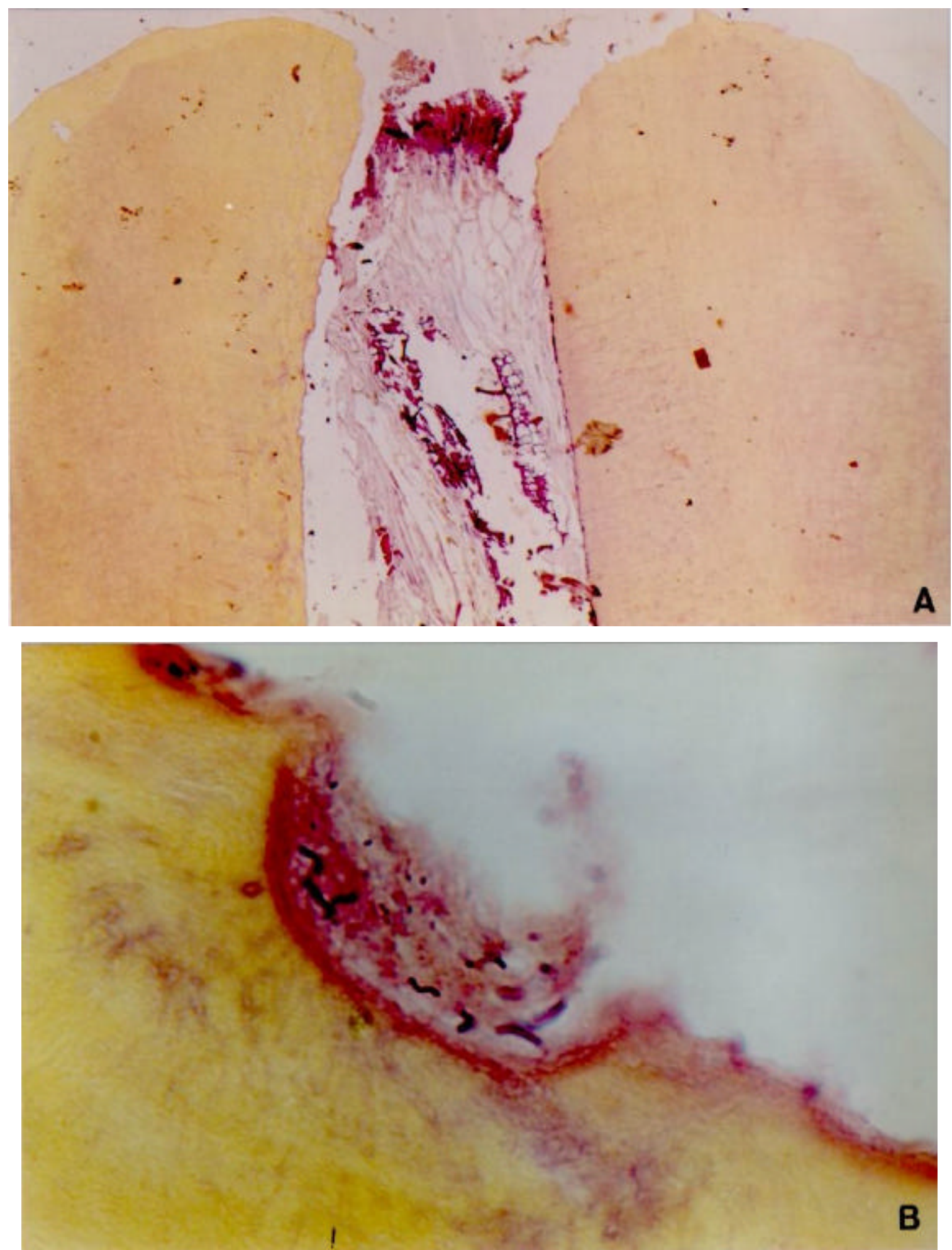

FIGURA 10 - Aspectos microscópicos do comprometimento das estruturas mineralizadas do terço apical de dente com necrose pulpar e lesão periapical crônica. Em B, observa-se a presença de bactérias em uma lacuna de Howship. 

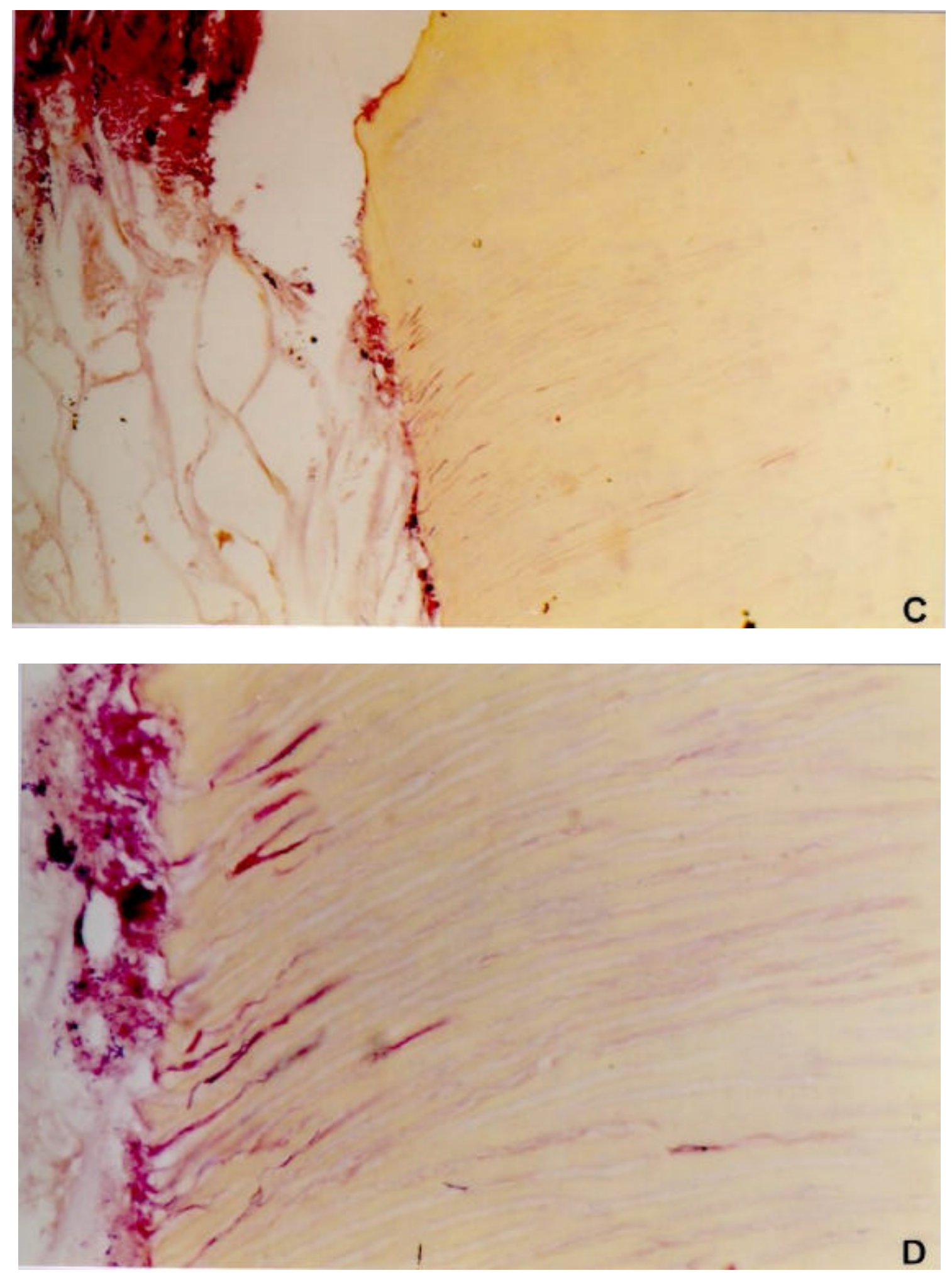

Em C e D, colônias bacterianas aderidas à parede irregular do canal, associadas à invasão bacteriana intratubular. (Aumento original: $\mathrm{A}=10 \mathrm{X}, \mathrm{B}=$ 400X, C = 40X, D = 160X, Brown e Brenn) 

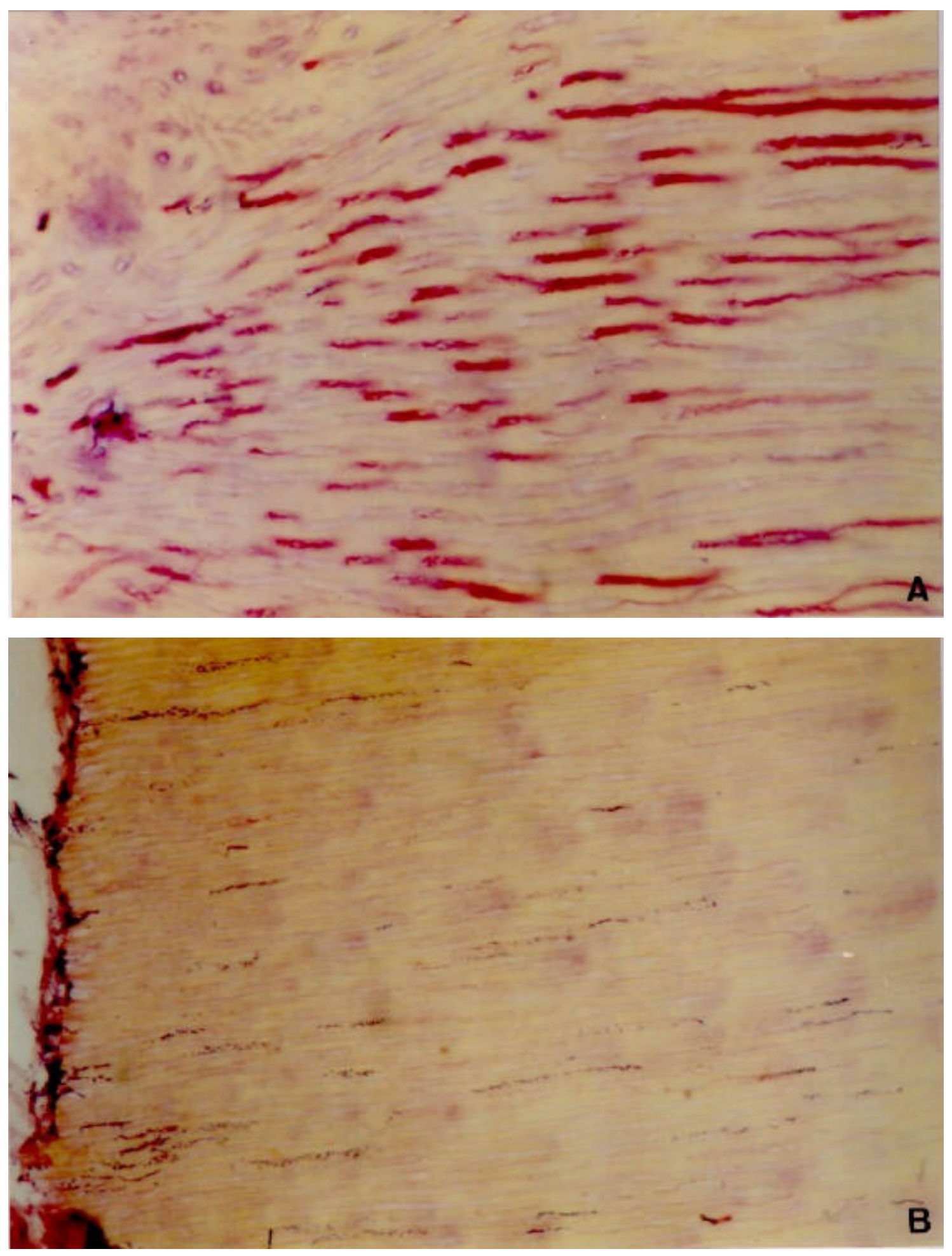

FIGURA 11 - Bactérias e colônias com localização intratubular. Em A, tem-se um campo predominantemente preenchido por bactérias Gramnegativas, com dificuldade de delineamento dos corpos bacterianos. Em B, predominantemente têm-se bactérias Gram-positivas. Os corpos bacterianos são bem definidos e distintos. 

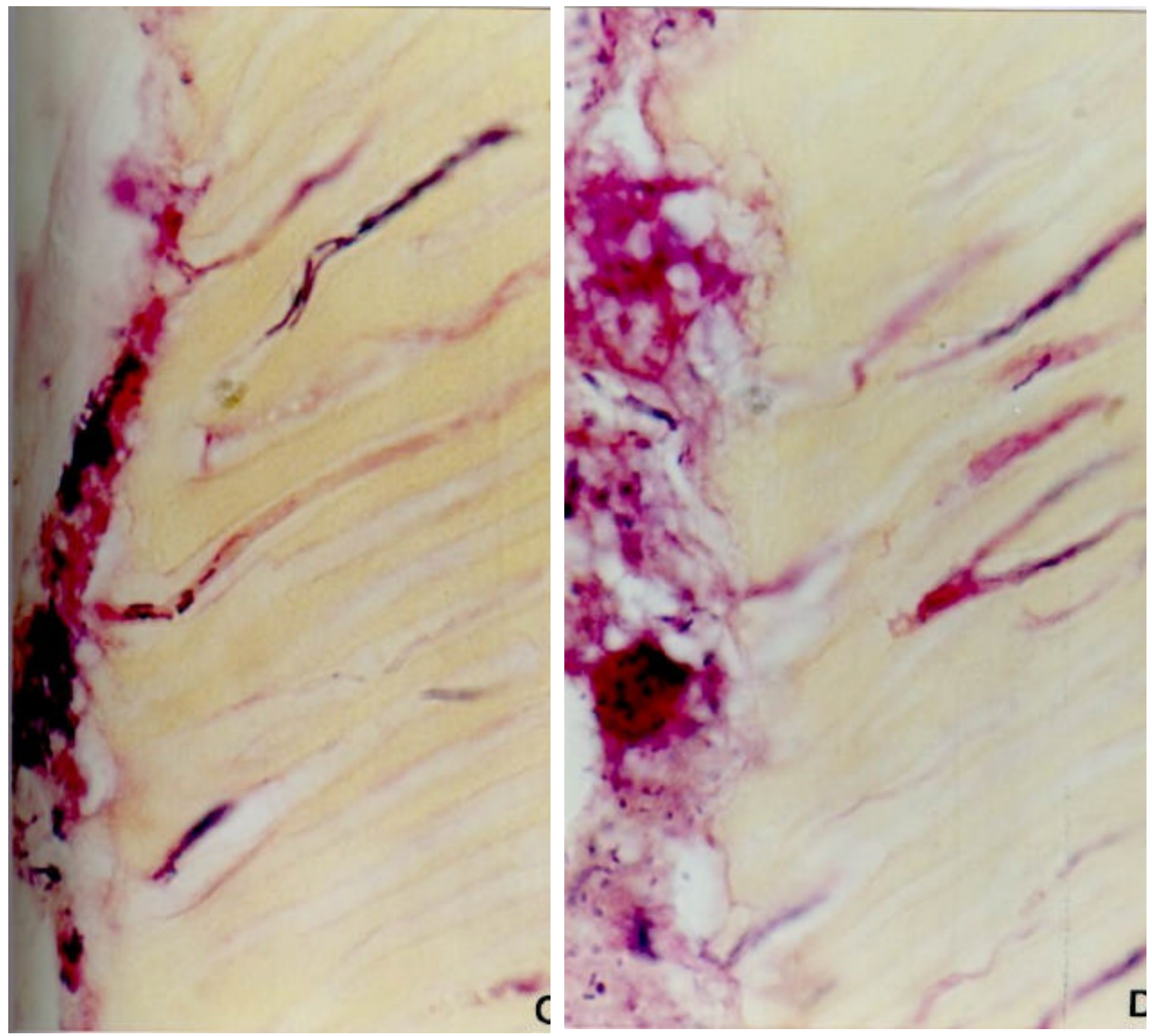

A forma de apresentação em maiores magnitudes estão presentes nas Figuras C e D, onde as bactérias Gram-positivas apresentam-se bem definidas, e as Gram-negativas em borrões avermelhados. Estes aspectos se repetem no lume do canal nas colônias livres e aderidas. (Aumento original: $\mathrm{A}=160 \mathrm{X}, \mathrm{B}=100 \mathrm{X}, \mathrm{C}=$ 400X, D = 400X, Brown e Brenn) 

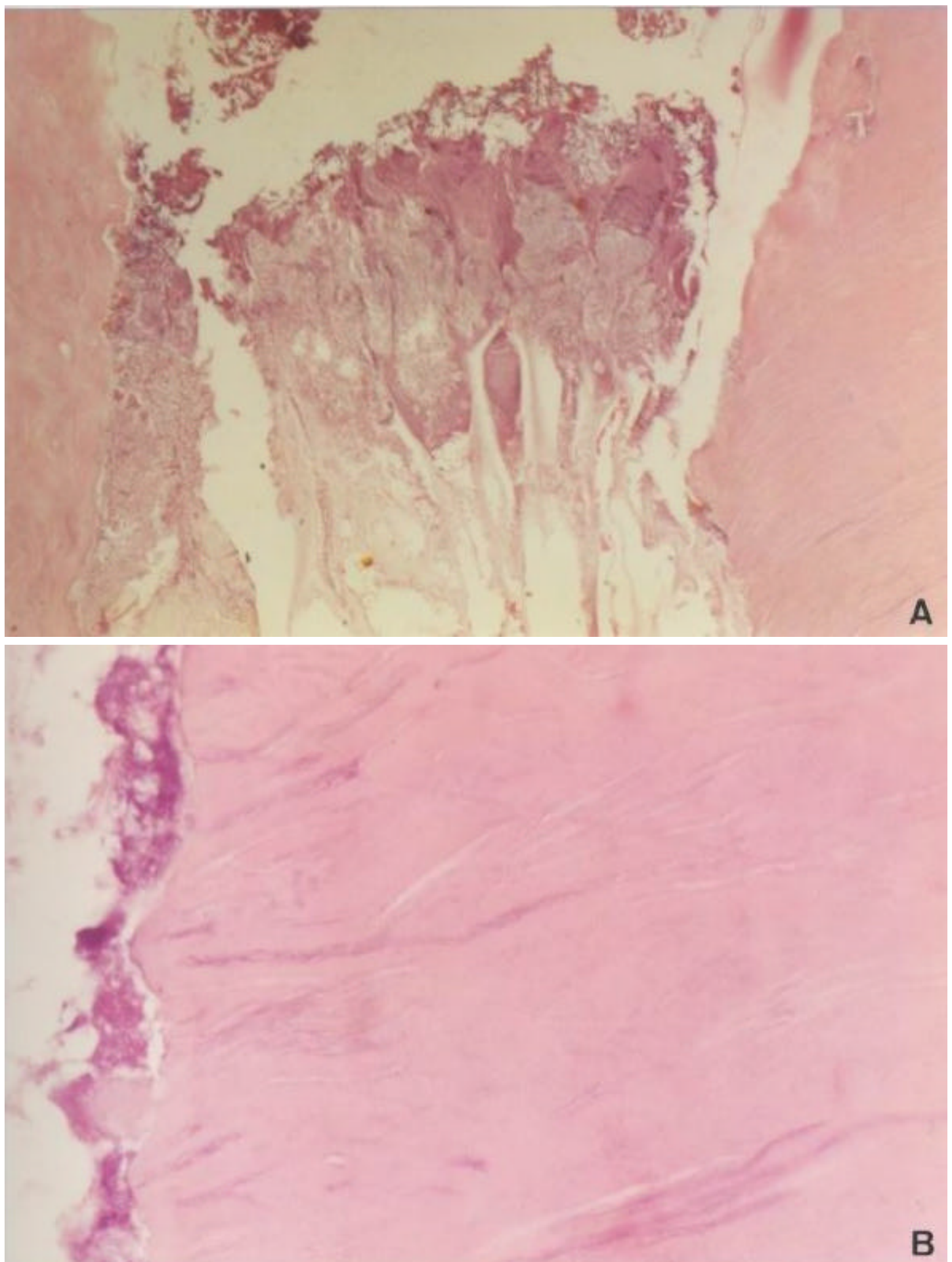

FIGURA 12 - Aspectos microscópicos do mesmo espécime das Figuras 9, 10 e 11 em coloração H.E. Observa-se que os aspectos morfológicos bacterianos são imprecisos e indefinidos, dificultando uma avaliação mais precisa; não permitindo uma distinção entre bactérias Grampositivas e Gram-negativas. (Aumento original: $\mathrm{A}=40 \mathrm{X}, \mathrm{B}=160 \mathrm{X}$ ) 

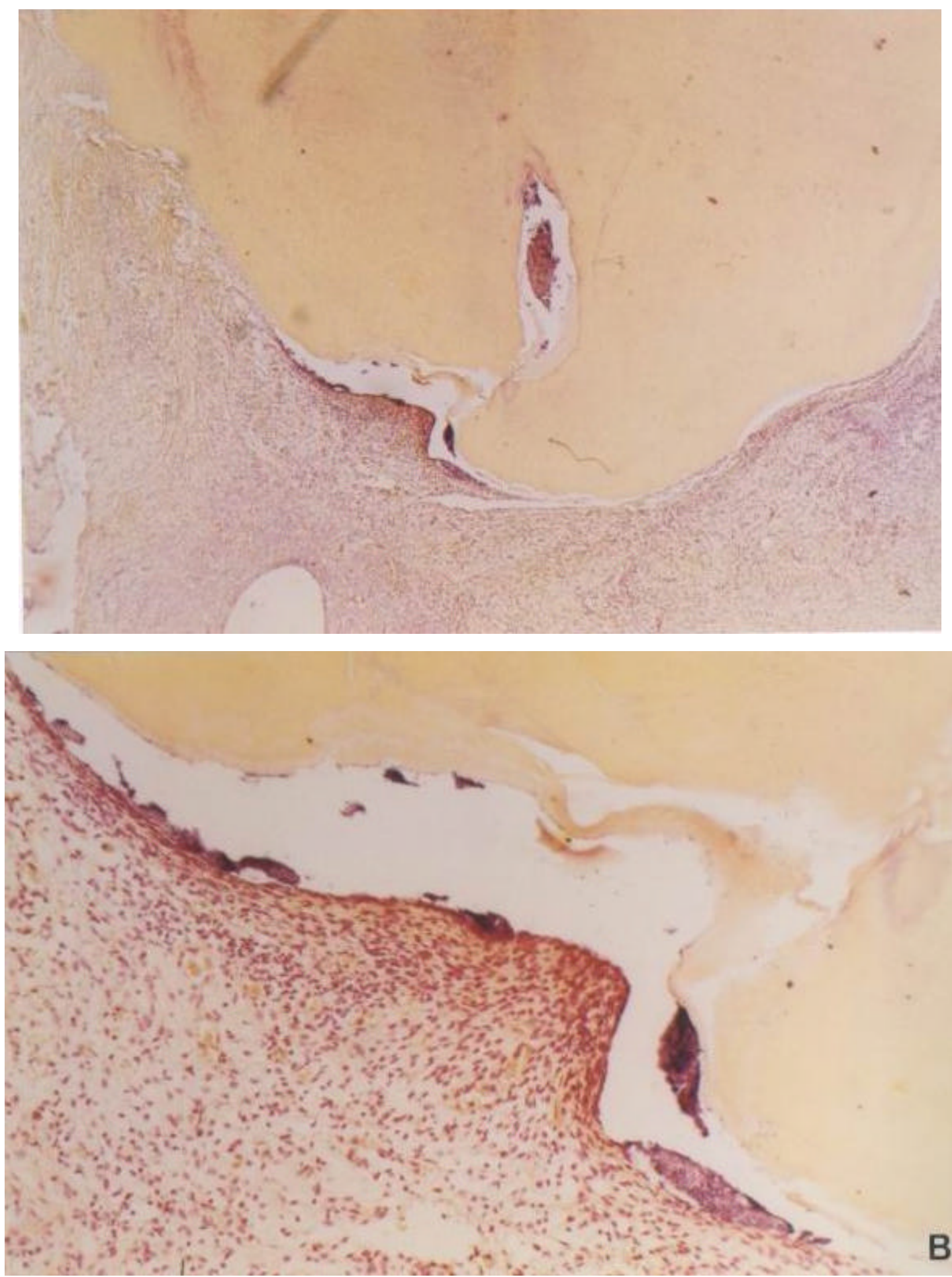

FIGURA 13 - Aspectos microscópicos de dente com necrose pulpar e granuloma apical apresentando placa dentobacteriana apical ou biofilme apical (setas maiores), bem como colônias bacterianas intracanal e bactérias localizadas em vacúolos intracelulares de macrófagos (setas menores). 

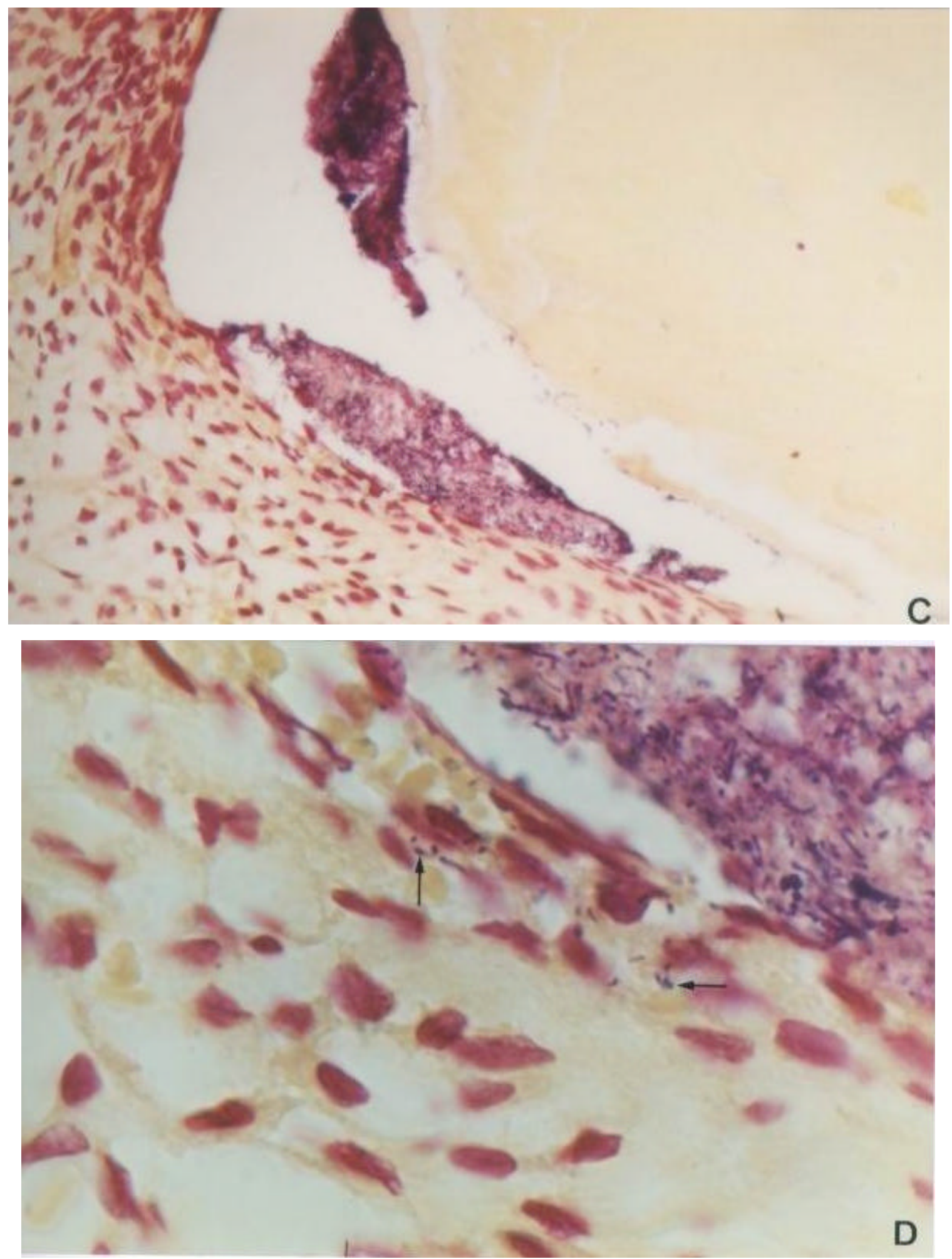

Destaca-se a colonização da superfície apical irregular. As bactérias identificadas nas várias áreas são Gram-positivas e Gram-negativas. (Aumento original: $\mathrm{A}=10 \mathrm{X}, \mathrm{B}=40 \mathrm{X}, \mathrm{C}=100 \mathrm{X}, \mathrm{D}=400 \mathrm{X}$, Brown e Brenn) 

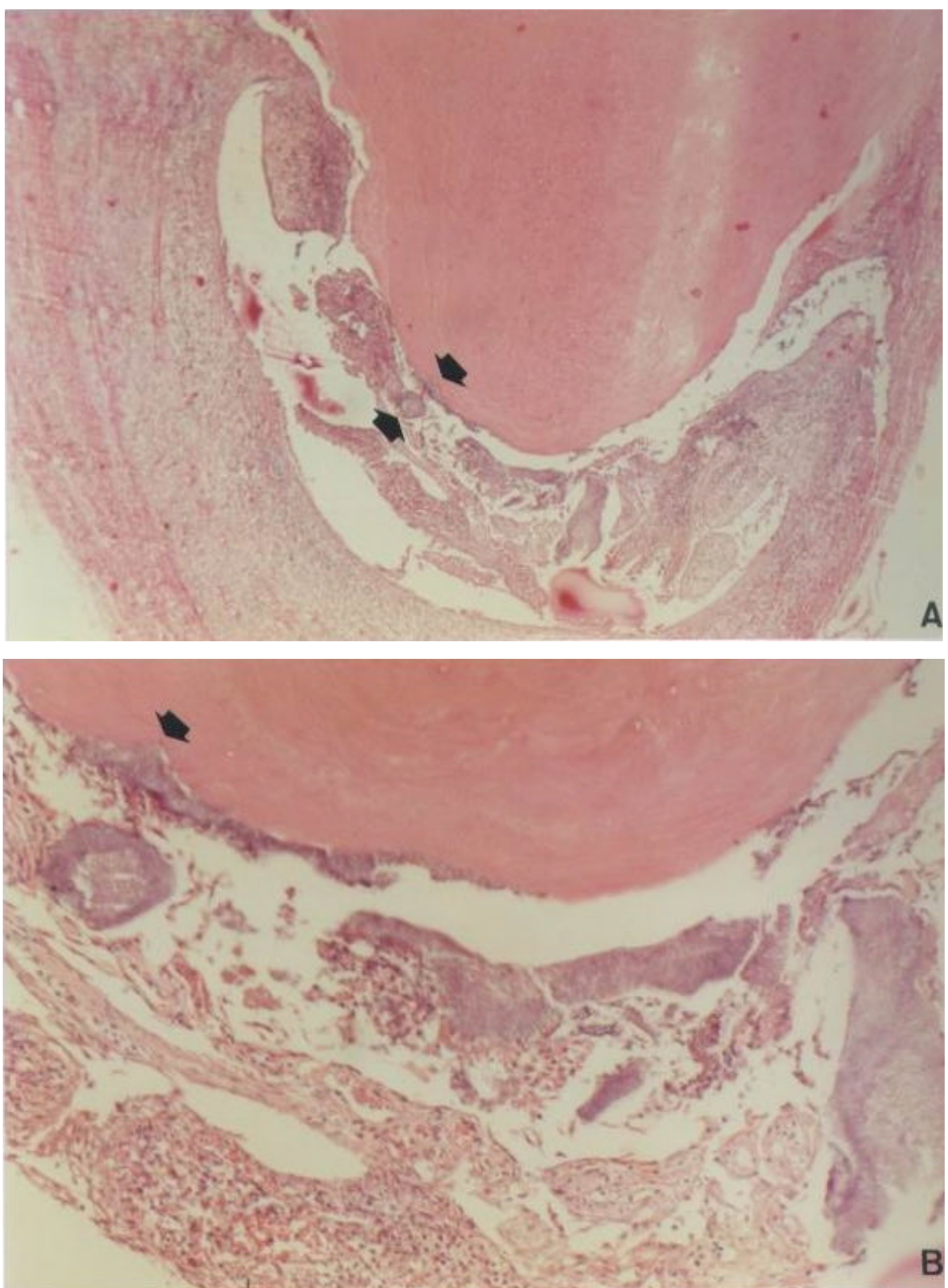

FIGURA 14 - Aspectos microscópicos da placa dentobacteriana apical ou biofilme apical (setas) em dentes com necrose pulpar e lesão periapical crônica. Destaca-se a colonização da superfície dentária apical, claramente evidenciada nos cortes corados pelas técnicas de Brown e Brenn (C e D). 

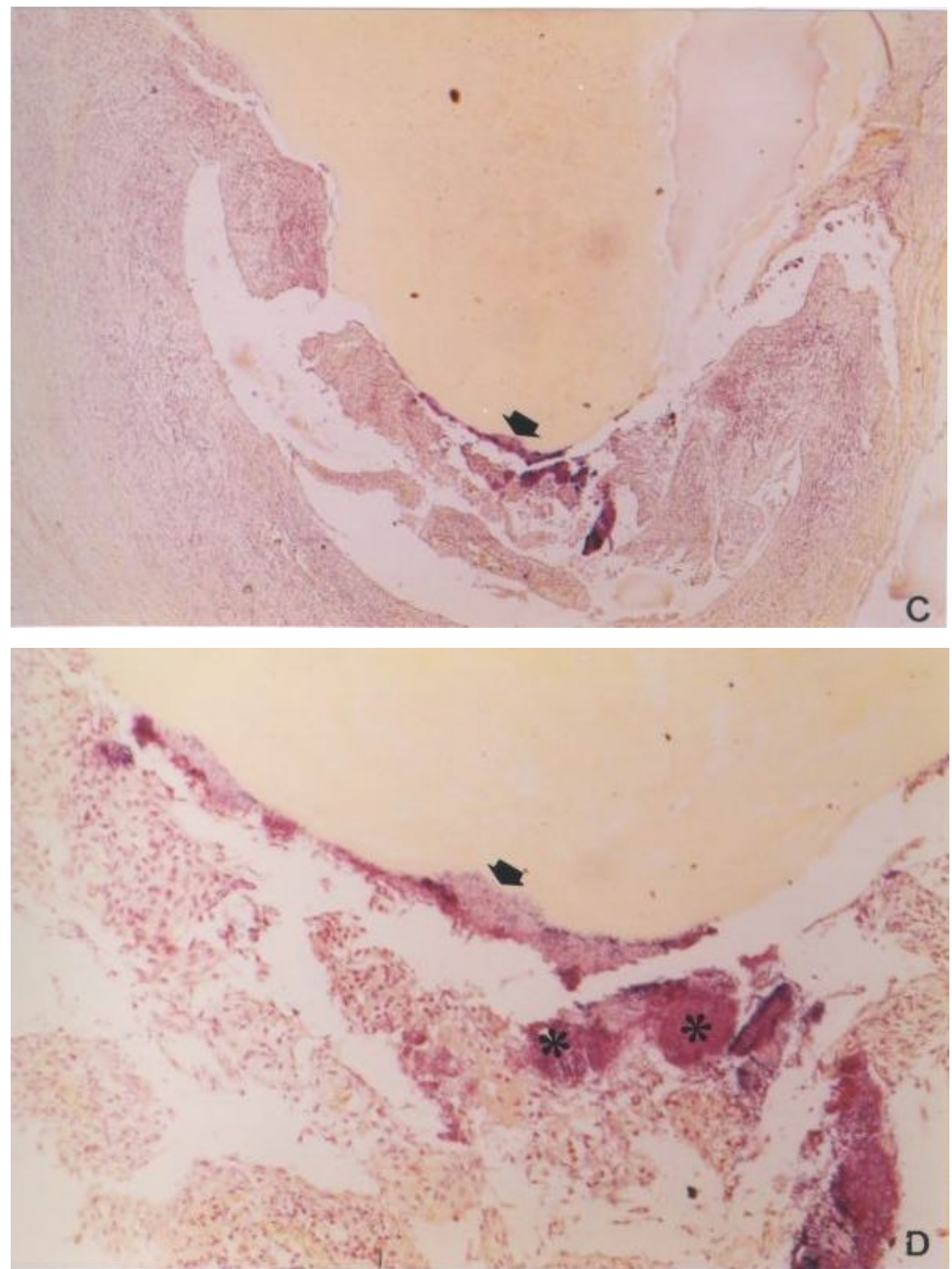

Associada à superfície colonizada tem-se ainda a presença de extensas colônias bacterianas Gram-positivas e Gram-negativas no granuloma apical (*). Na Figura seguinte, serão apresentadas imagens em magnitudes maiores desse mesmo espécime. (Aumento original: $\mathrm{A}=10 \mathrm{X}, \mathrm{B}=40 \mathrm{X}, \mathrm{H} . \mathrm{E}$.; $\mathrm{C}=10 \mathrm{X}, \mathrm{D}=40 \mathrm{X}$, Brown e Brenn) 

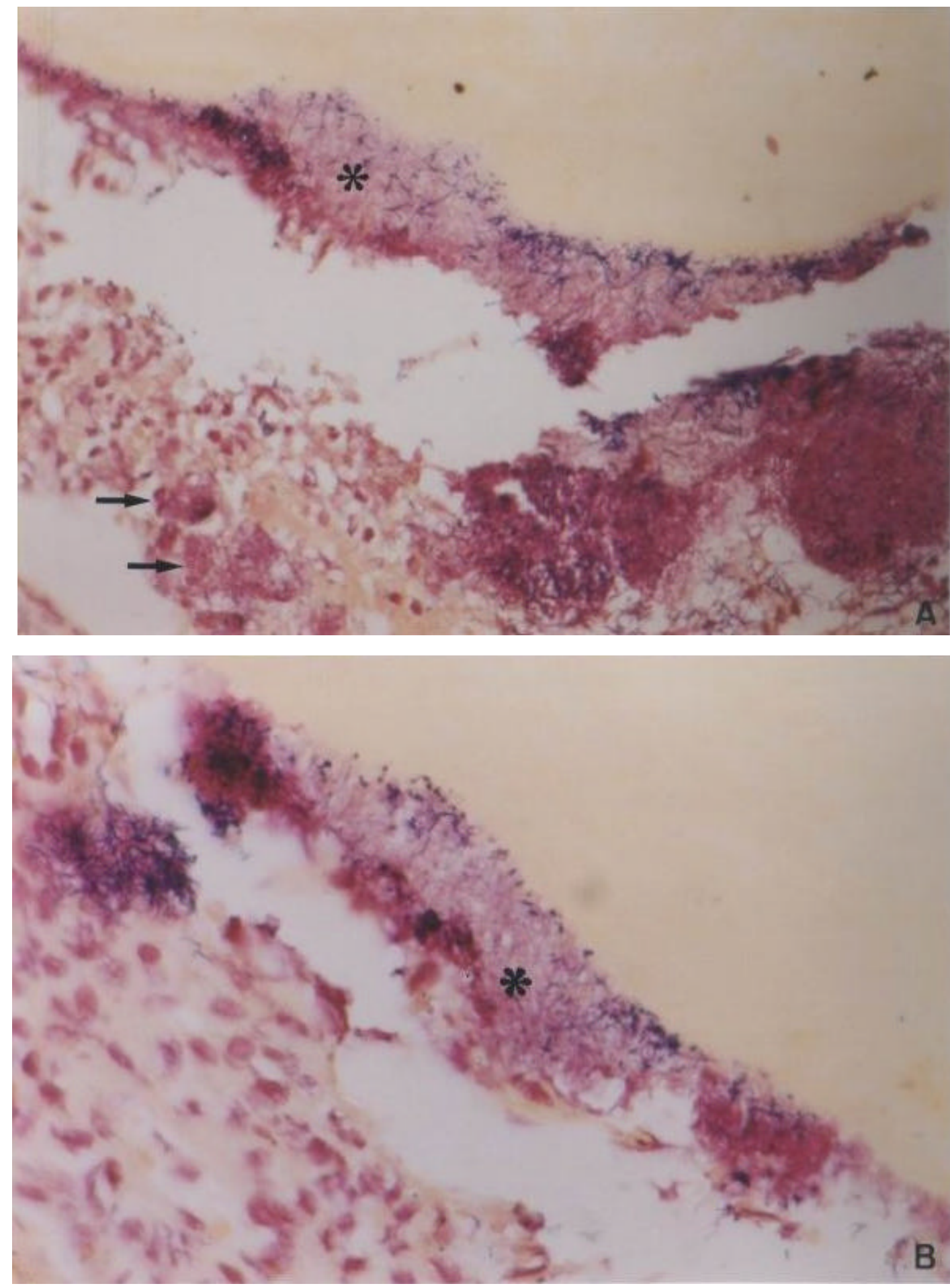

FIGURA 15 - Placa dentobacteriana ou biofilme apical (*) em superfície dentária apical irregular de dente com necrose pulpar e lesão periapical crônica. Observa-se a constituição por bactérias Gram-positivas e Gram-negativas, além de colônias bacterianas livres e a distância da superfície apical no interior do granuloma (setas), Gram-positivas e Gram-negativas. 

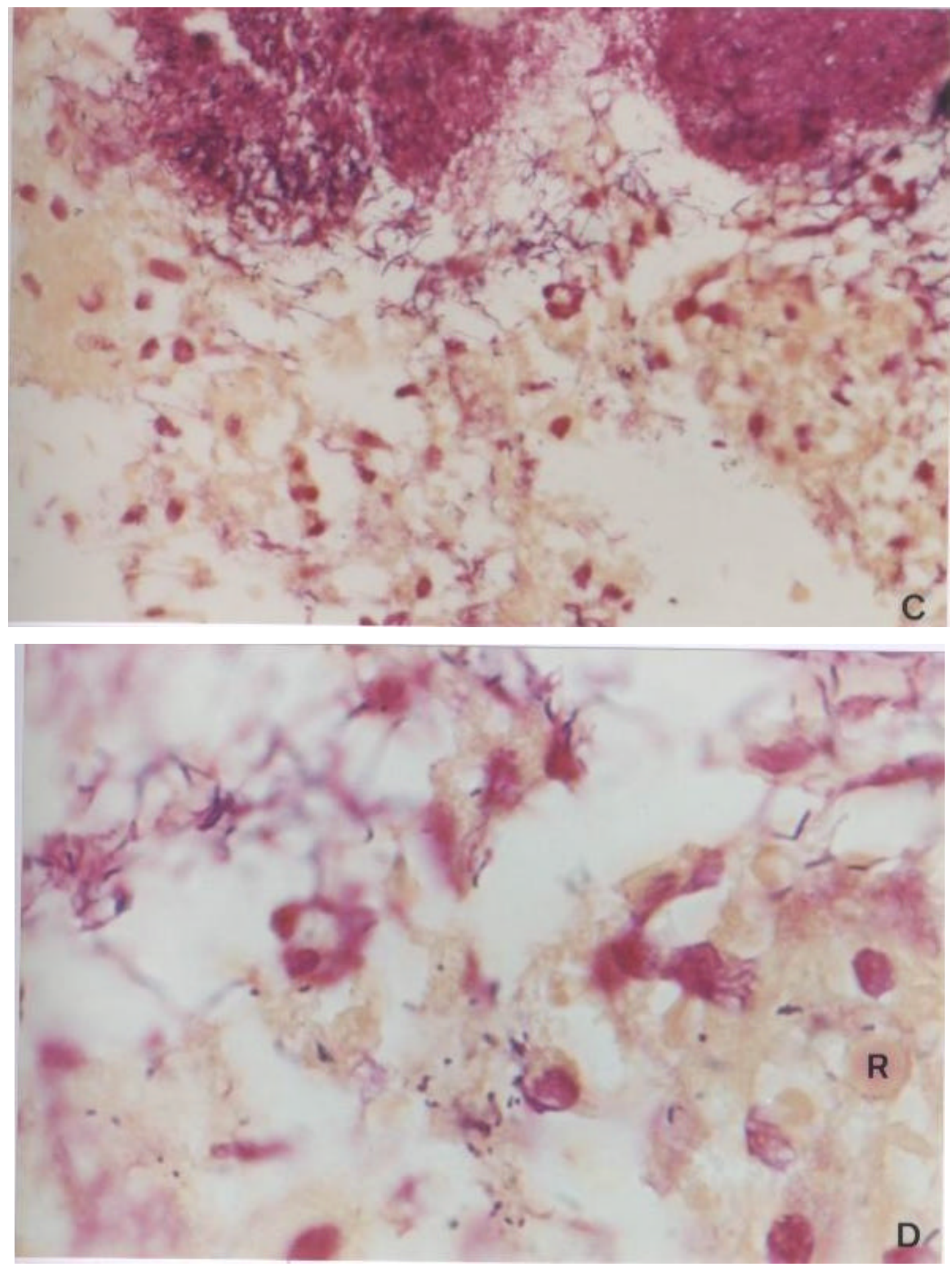

Nas células do granuloma apical, presença de bactérias ora visivelmente intracelulares, ora de localização indefinida. Vê-se ainda no corte, corpúsculo hialino de Russel (R). (Aumento original: A = 100X, B e C $=160 \mathrm{X}, \mathrm{D}=$ 400X, Brown e Brenn) 

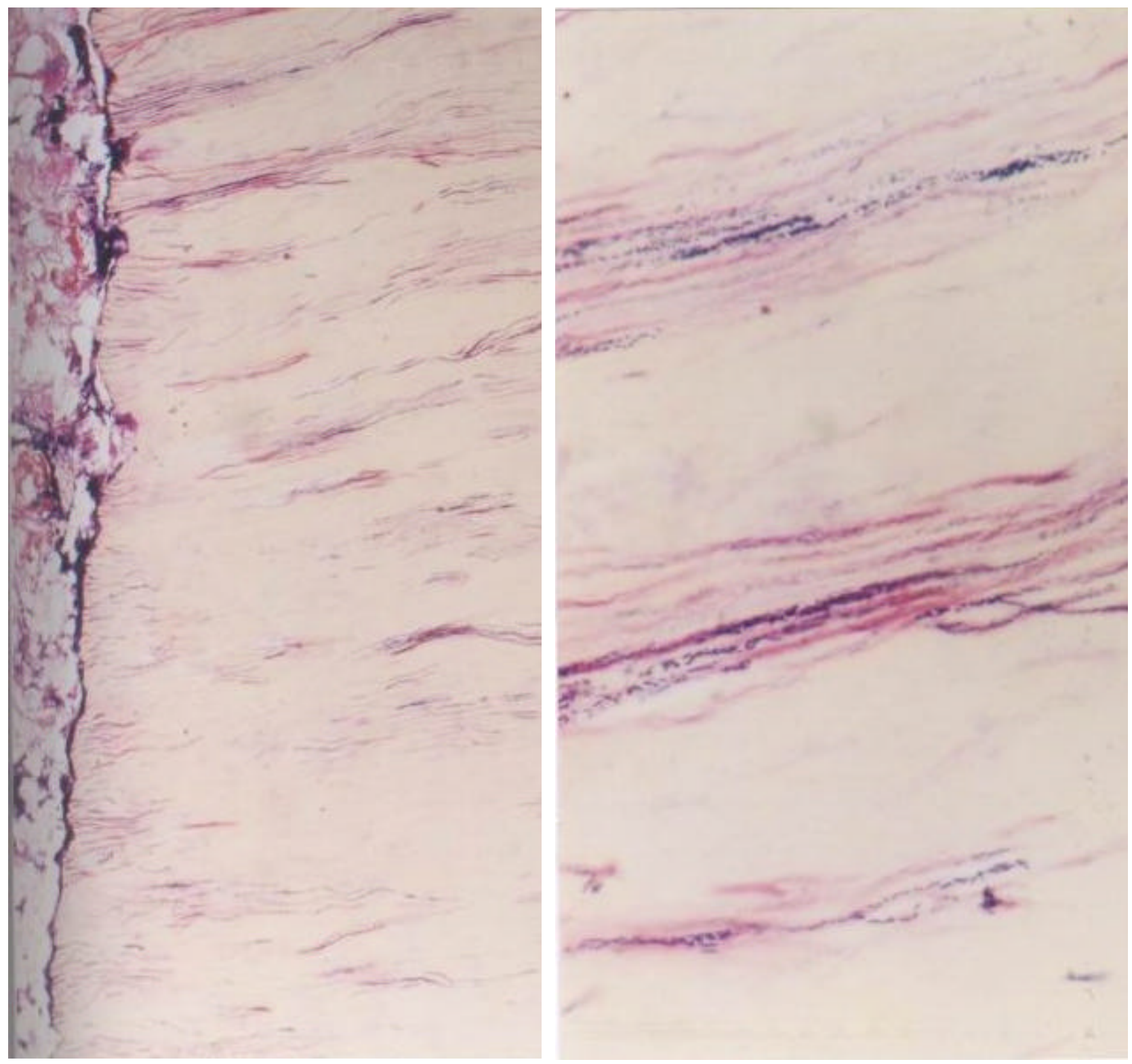

FIGURA 16 - Presença intratubular de bactérias Gram-positivas e Gram-negativas, alcançando os três terços dentinários, em cortes longitudinais de dentes com necrose pulpar e granuloma apical. Na irregular superfície interna do canal radicular, colônias bacterianas Grampositivas e Gram-negativas. (Aumento original: $\mathrm{A}=40 \mathrm{X}, \mathrm{B}=160 \mathrm{X}$, Brown e Brenn) 


\section{2 - Grupo B - Dentes com granulomas, terços apicais cortados transversalmente}

Os cortes neste grupo mostravam, numa vista panorâmica do terço apical radicular, o lume do canal principal e das ramificações constituintes do delta apical, como também a inter-relação entre a superfície radicular lateral apical e o granuloma apical, como se pode ver na Figura 22.

\subsection{1 - Observações relativas ao canal radicular (Figura 17)}

Aos cortes transversais do terço apical, os canais radiculares de nove espécimes apresentaram-se com formas aproximadamente circulares. Dos sete espécimes remanescentes, cinco lembravam uma forma ovalada, um elíptica e o outro em C.

Dos 16 espécimes da amostragem, 8 mostraram aberturas correspondentes as foraminas, constituintes do delta apical. Estas apresentavam-se distribuídas aleatoriamente na porção cementária, numa variação de 1 a 11 por espécime.

Alguns depósitos de dentina reacional, com variações na forma e na espessura, foram observados ao longo da circunferência do canal, não necessariamente de forma contínua. Em alguns espécimes, observaram-se lacunas correspondentes a inclusões celulares, contidas nesta dentina ora vazias, ora preenchidas por restos necróticos e/ou colônias bacterianas (Figuras 28, 29, 30, 31 e 32). 
Em todos os espécimes observaram-se, no espaço correspondente ao canal radicular, restos necróticos permeados por colônias bacterianas, predominantemente formadas por cocos e bacilos Gram-positivos e Gramnegativos, livres e aderidas às paredes do canal. Em alguns espécimes, além deste conteúdo, restos alimentares e células inflamatórias se fizeram presentes (Figuras 28 e 32).

\subsection{2 - Observações relativas à dentina radicular apical (Figura 18)}

A incidência do corte e a presença bacteriana evidenciaram claramente, a divergência na orientação dos túbulos dentinários, no sentido da junção cemento-dentina, lembrando vagamente a figura esquemática dos raios solares, como se pode ver na Figura 27.

$\mathrm{Na}$ maioria dos espécimes, observaram-se bactérias nos túbulos dentinários, estendendo-se do terço pulpar ao terço médio, raramente atingindo o terço superficial da camada dentinária, e cujos aspectos morfológicos evidenciados pela técnica de coloração de Brown e Brenn permitiram-nos concluir tratar-se de cocos e bacilos Gram-positivos e Gram-negativos, com predomínio das formas Gram-negativas. A densidade bacteriana intratubular foi predominantemente leve, contribuindo para a preservação dos túbulos.

Em alguns dentes notou-se a presença de colônias bacterianas no interior da dentina reacional, alojadas em áreas com defeitos de mineralização ou lacunas ocupadas por restos de células aprisionadas durante a sua formação. 
partir destes locais, observou-se a permeação bacteriana para os túbulos dentinários adjacentes, como acha-se demonstrada nas Figuras 29 e 30.

\subsection{3 - Observações relativas ao canal cementário (Figura 19)}

Em 15 espécimes, onde colônias bacterianas foram detectadas, estas apresentavam-se localizadas no lume do canal principal e acessórios, nas lacunas de reabsorção e nos cementoplastos (Figuras 22, 23, 24 e 34).

Nas paredes do canal cementário de aproximadamente, metade dos espécimes, notaram-se áreas de reabsorções, com aspecto rendilhado, e em cujas lacunas encontravam-se freqüentemente bactérias isoladas ou organizadas em colônias.

No canal cementário próximo à abertura correspondente ao forame apical, observaram-se freqüentemente polimorfonuclares em interação com bactérias isoladas, ou em colônias formadas por cocos e bacilos Gram-positivos e Gram negativos, e esporadicamente espirilos.

\subsection{4 - Observações relativas à superfície apical (Figura 20)}

$\mathrm{Na}$ maioria dos espécimes, a superfície radicular apresentou-se irregular por reabsorção. Em cinco espécimes estas reabsorções atingiram a parede dentinária. Em dois deles, observaram-se bactérias no interior dos túbulos dentinários intimamente relacionadas com os tecidos da região periapical. 
Em sete espécimes encontraram-se colônias bacterianas aderidas à superfície apical, identificadas como placas dentobacterianas, distribuídas nas superfícies regulares e irregulares do cemento e da dentina desnuda. Nestas colônias, foram identificados, predominantemente, cocos e bacilos (Figuras 22, 26 e 35).

\subsection{5 - Observações relativas aos granulomas apicais (Figura 21)}

Aos cortes, os granulomas apicais apresentavam-se ora posicionados lateralmente aos ápices radiculares, ora circunscrevendo-os, provavelmente devido às variações anatômicas do terço apical radicular, tais como dilacerações e diferentes posições da abertura correspondente ao forame apical.

Em 15 espécimes, passíveis de análise, detectaram-se bactérias Gram-positivas e Gram-negativas no interior dos granulomas apicais, isoladas e/ou organizadas em colônias. Quando isoladas, estas apresentavam-se distribuídas nos espaços extracelulares ou no interior de células macrofágicas. As colônias localizavam-se com maior freqüência nas imediações da superfície apical, mas não necessariamente, pois em alguns espécimes foram encontradas centralmente ou na periferia da lesão (Figuras 22, 25, 34 e 35). 

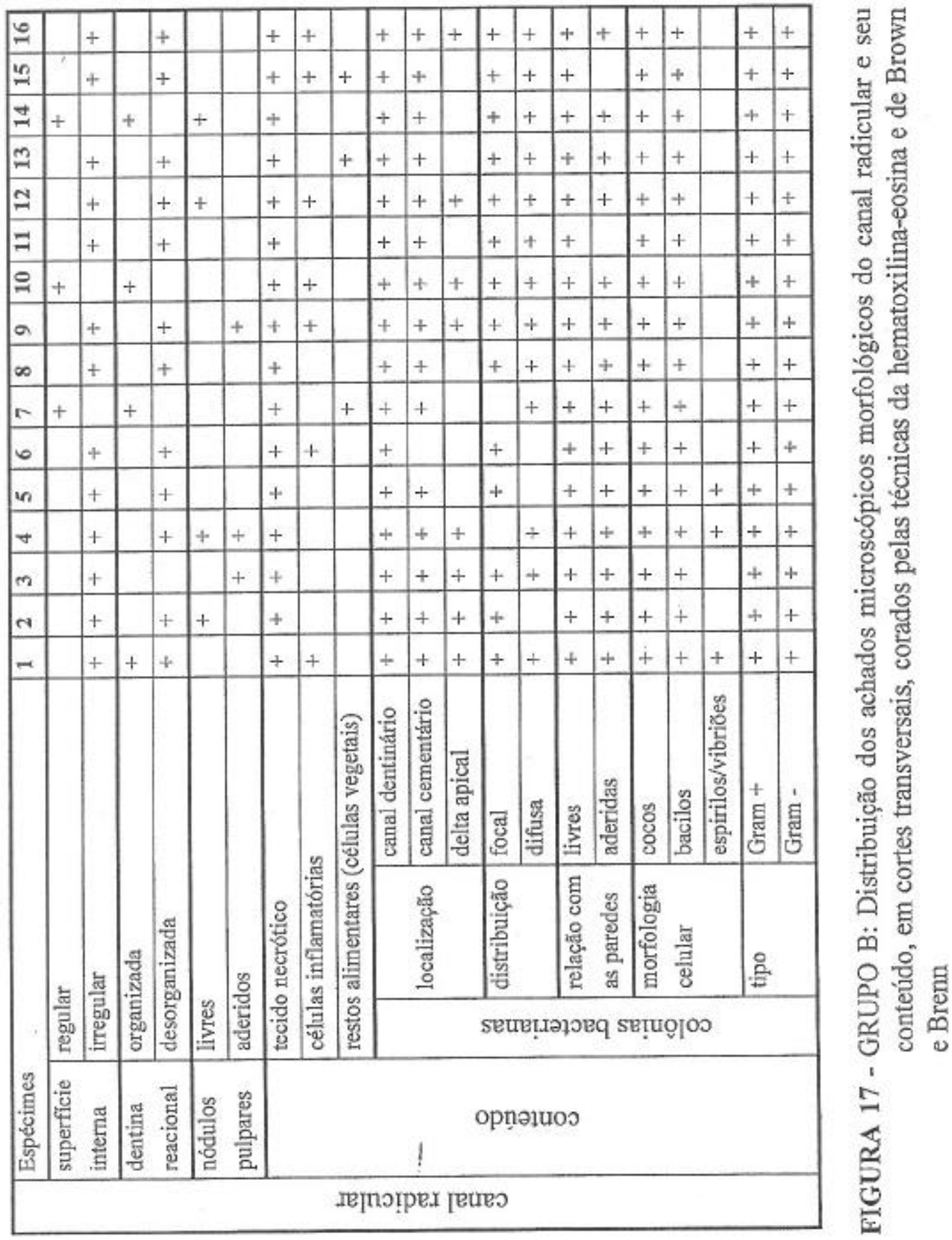

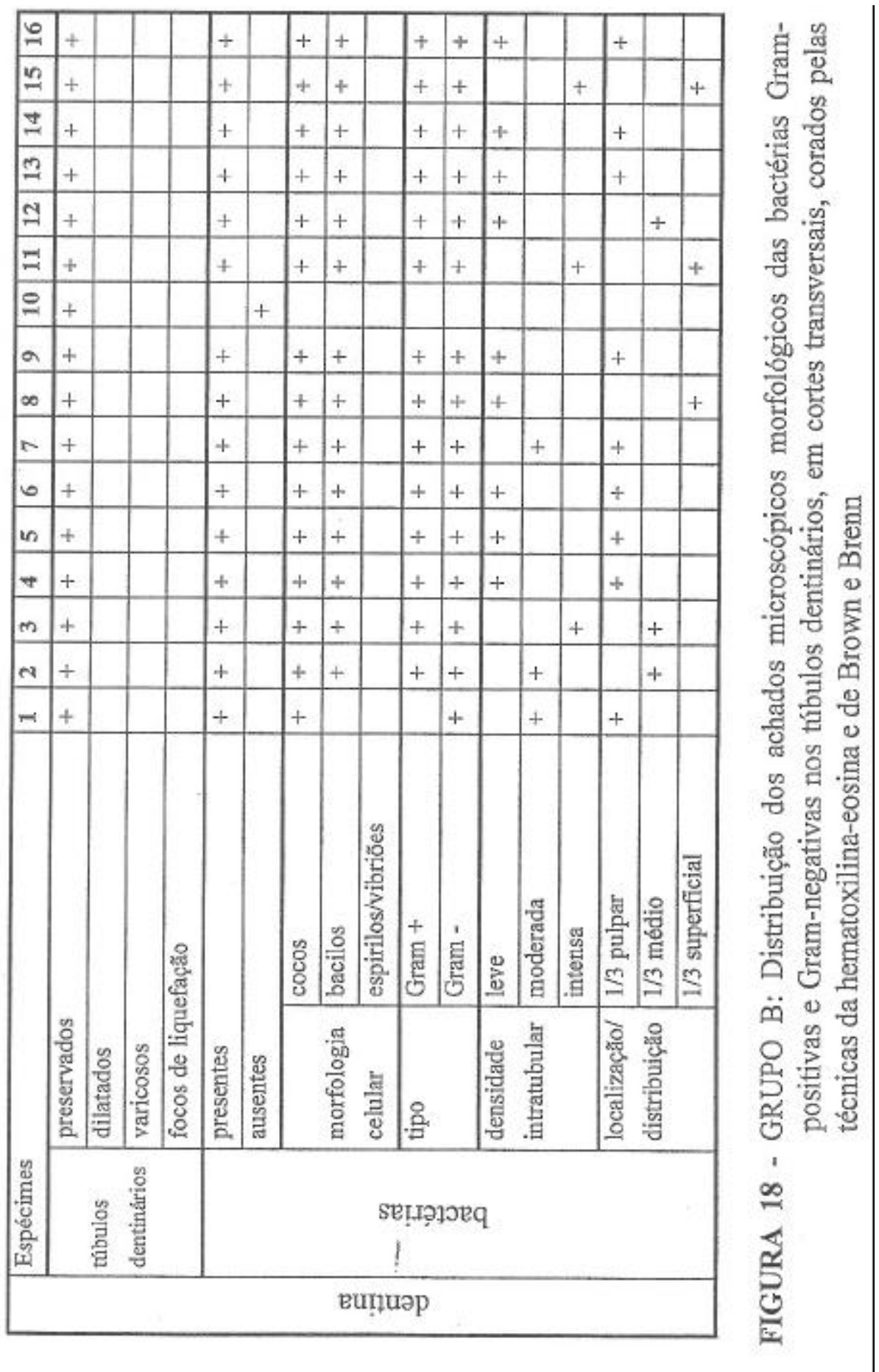

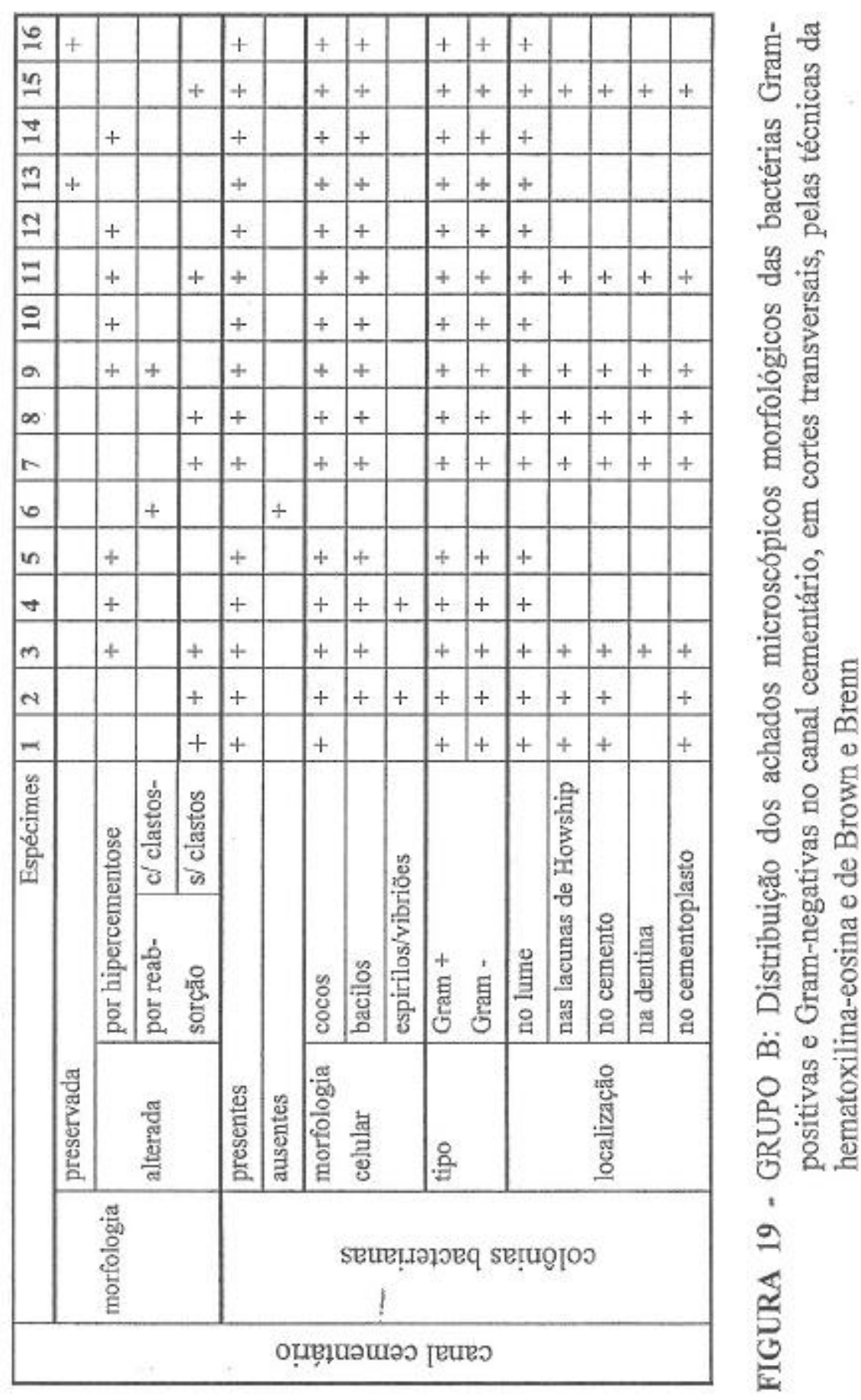

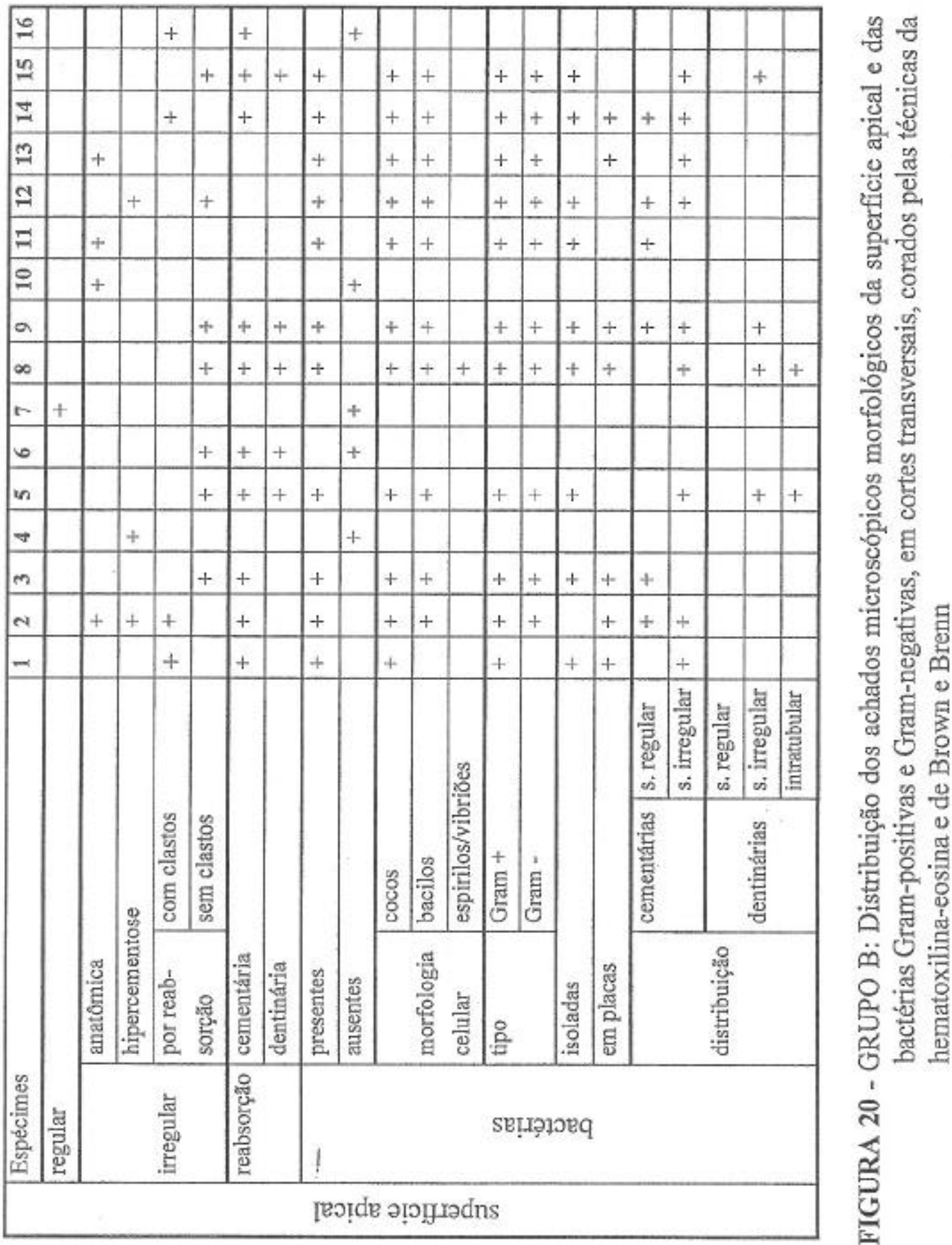

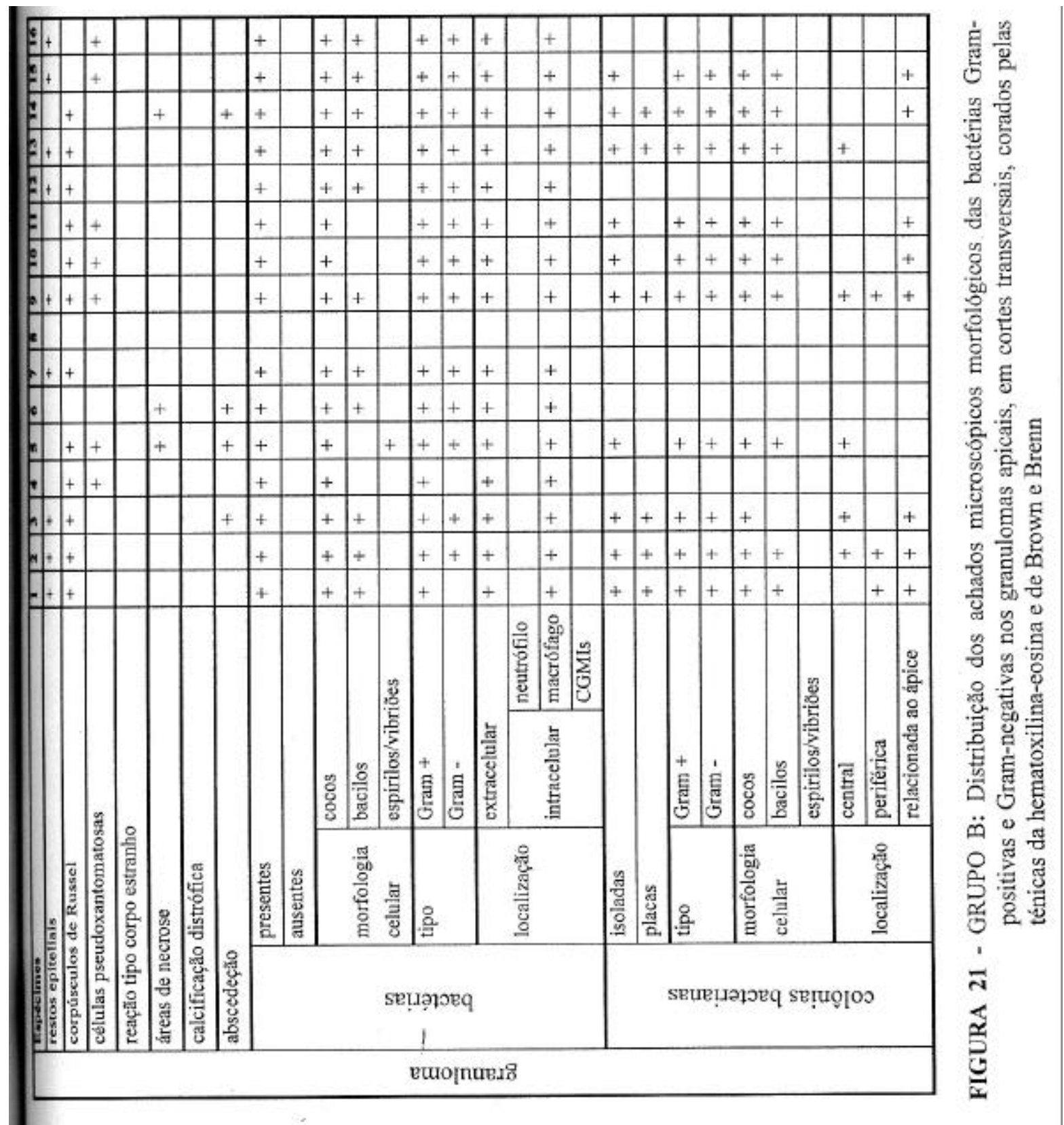

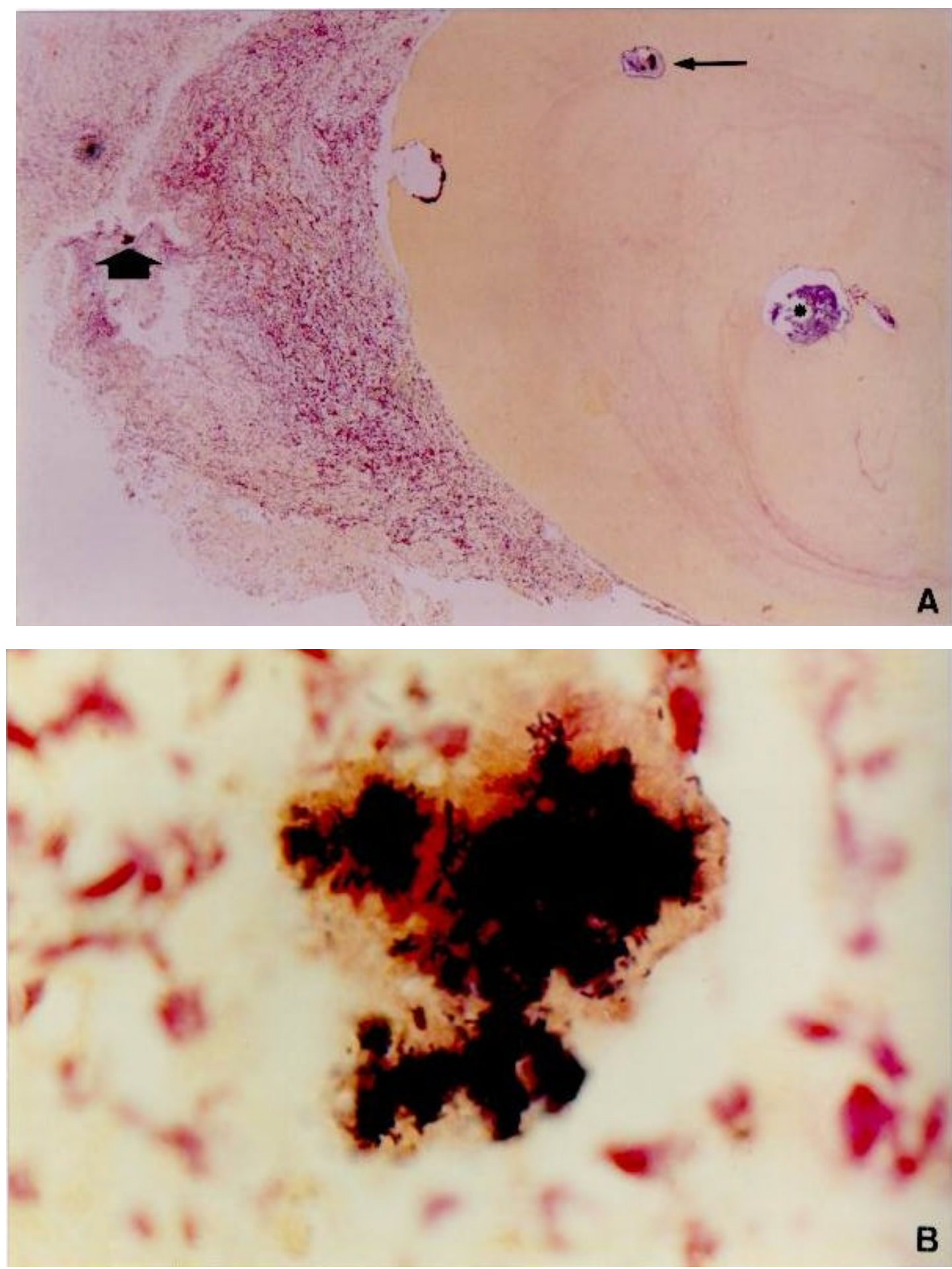

FIGURA 22 - Aspectos microscópicos de dente com necrose pulpar e granuloma apical onde se observa presença de colônias bacterianas no sistema de canais radiculares, canal principal $(*)$, acessório (seta) e na superfície apical em áreas de reabsorção dentária, evidenciada mais detalhadamente em $\mathrm{C}$ e D. 

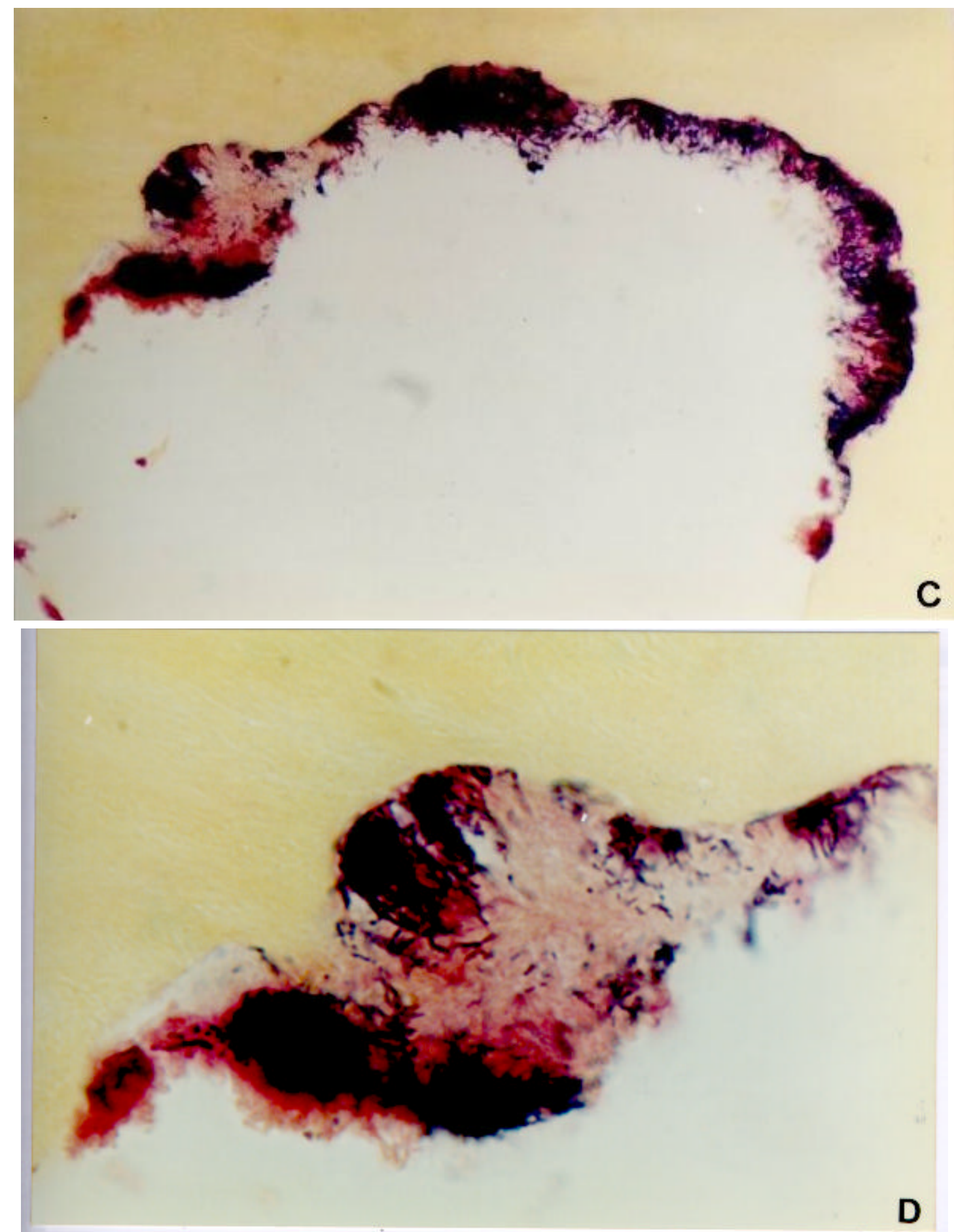

No granuloma apical, observam-se colônias bacterianas à distância da superfície radicular (seta maior), evidenciada em B, onde se vêem bactérias Gram-positivas e Gram-negativas na sua constituição. Em C e D, em várias lacunas de Howship, vê-se a colonização bacteriana Gram-positiva e Gram-negativa da superfície radicular irregular. (Aumento original: $\mathrm{A}=10 \mathrm{X}, \mathrm{B}=400 \mathrm{X}, \mathrm{C}=100 \mathrm{X}, \mathrm{D}$ $=400 \mathrm{X}$, Brown e Brenn) 

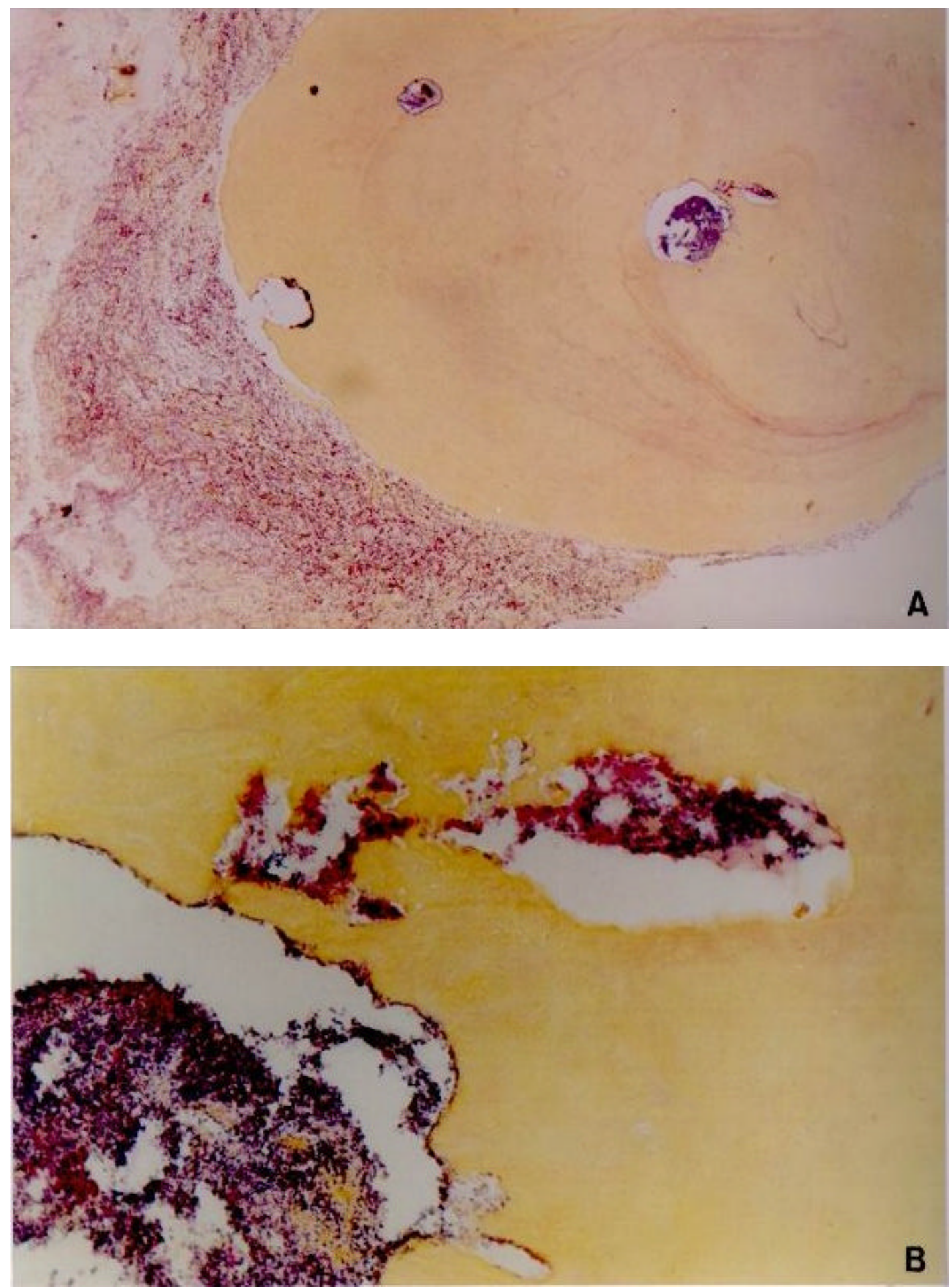

FIGURA 23 - No mesmo espécime da figura anterior de dente com necrose pulpar e granuloma apical, no canal principal e acessório, as colônias bacterianas e bactérias livres encontram-se largamente presentes, colonizando as paredes internas e as anfractuosidades, formando placas ou biofilmes bacterianos (setas). 

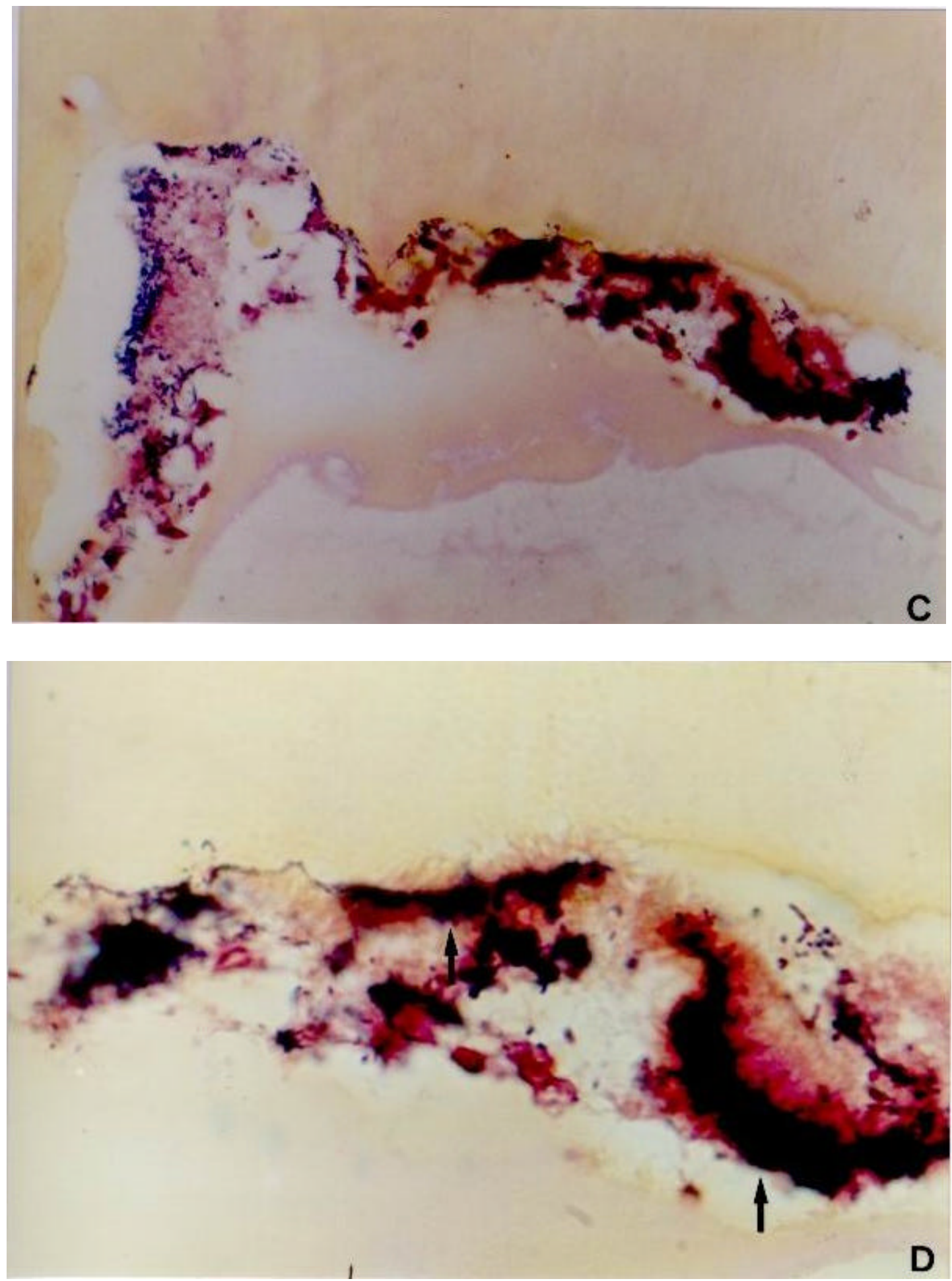

Nestes cortes, observa-se a presença de bactérias Gram-positivas e Gram-negativas. (Aumento original: $\mathrm{A}=10 \mathrm{X}, \mathrm{B}=100 \mathrm{X}, \mathrm{C}=160 \mathrm{X}, \mathrm{D}=400 \mathrm{X}$, Brown e Brenn) 

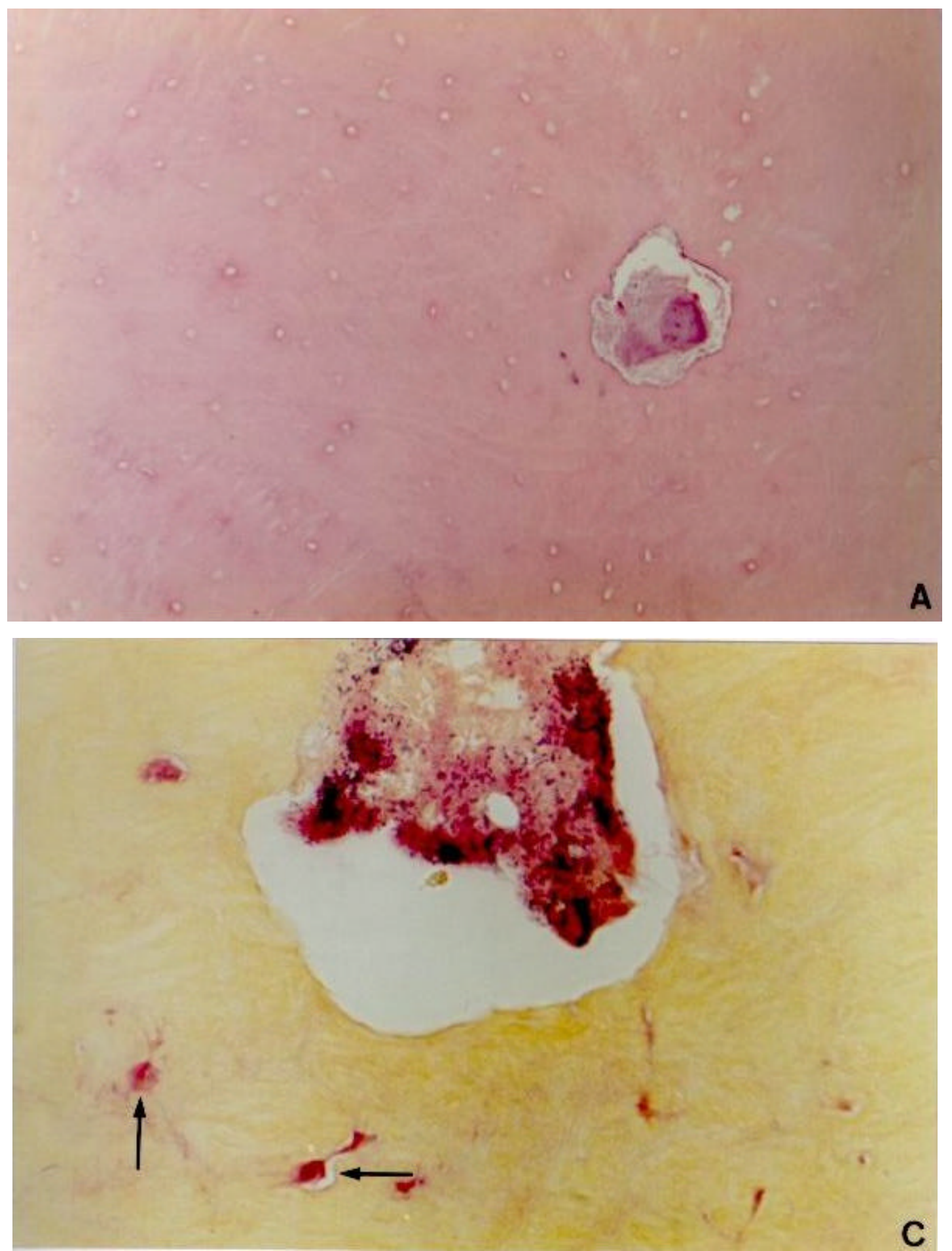

FIGURA 24 - Canal acessório de dente com necrose pulpar e granuloma apical, onde se observam colônias bacterianas no lume e nos cementoplastos. 

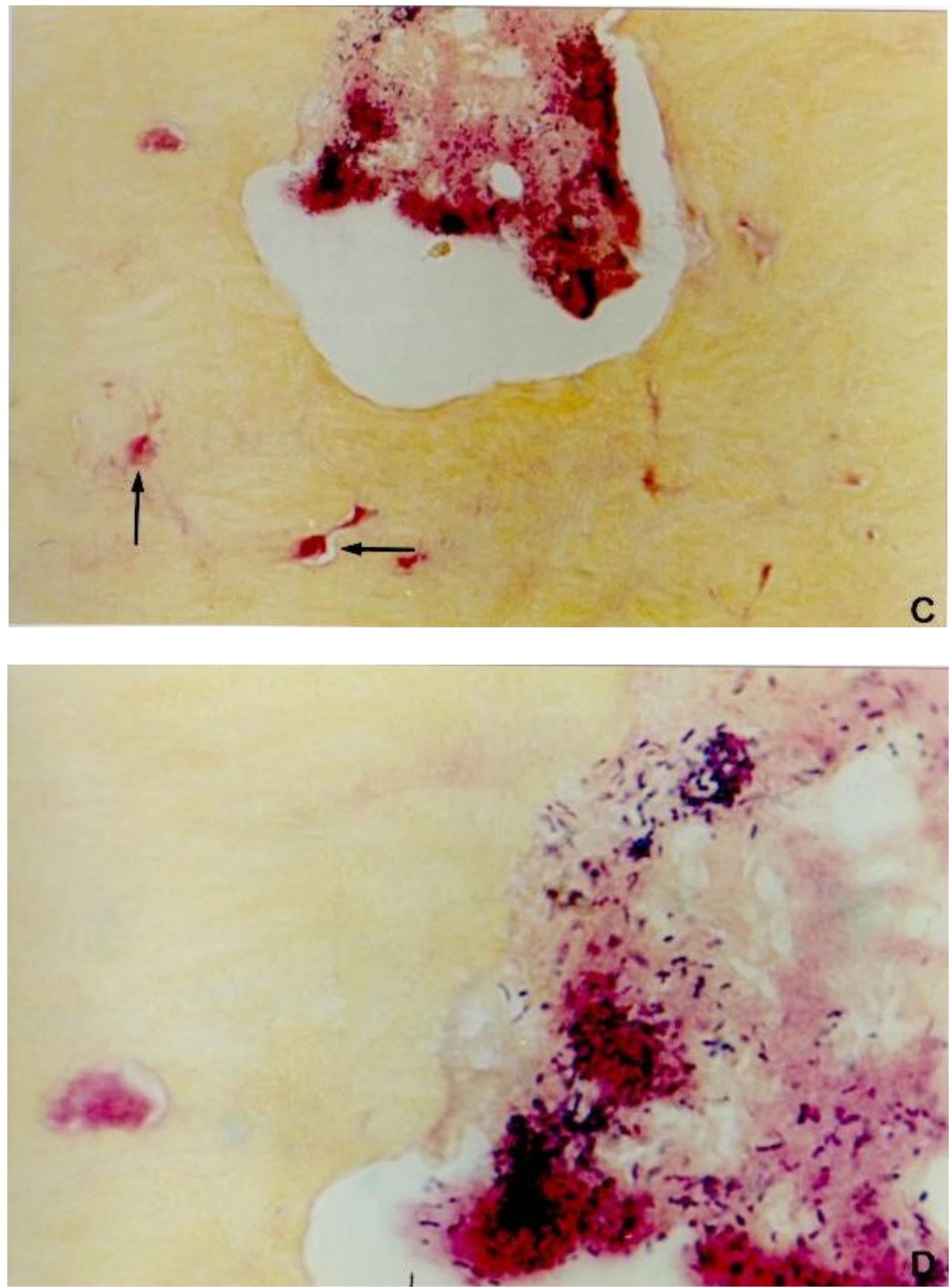

Nestes, as bactérias são predominantemente Gram-negativas (setas), bem evidenciadas pela coloração de Brown e Brenn, mas pouco observadas em cortes por H.E. (Aumento original: $\mathrm{A}=40 \mathrm{X}$, H.E.; $\mathrm{B}=100 \mathrm{X}, \mathrm{C}=160 \mathrm{X}, \mathrm{D}=$ 400X, Brown e Brenn) 

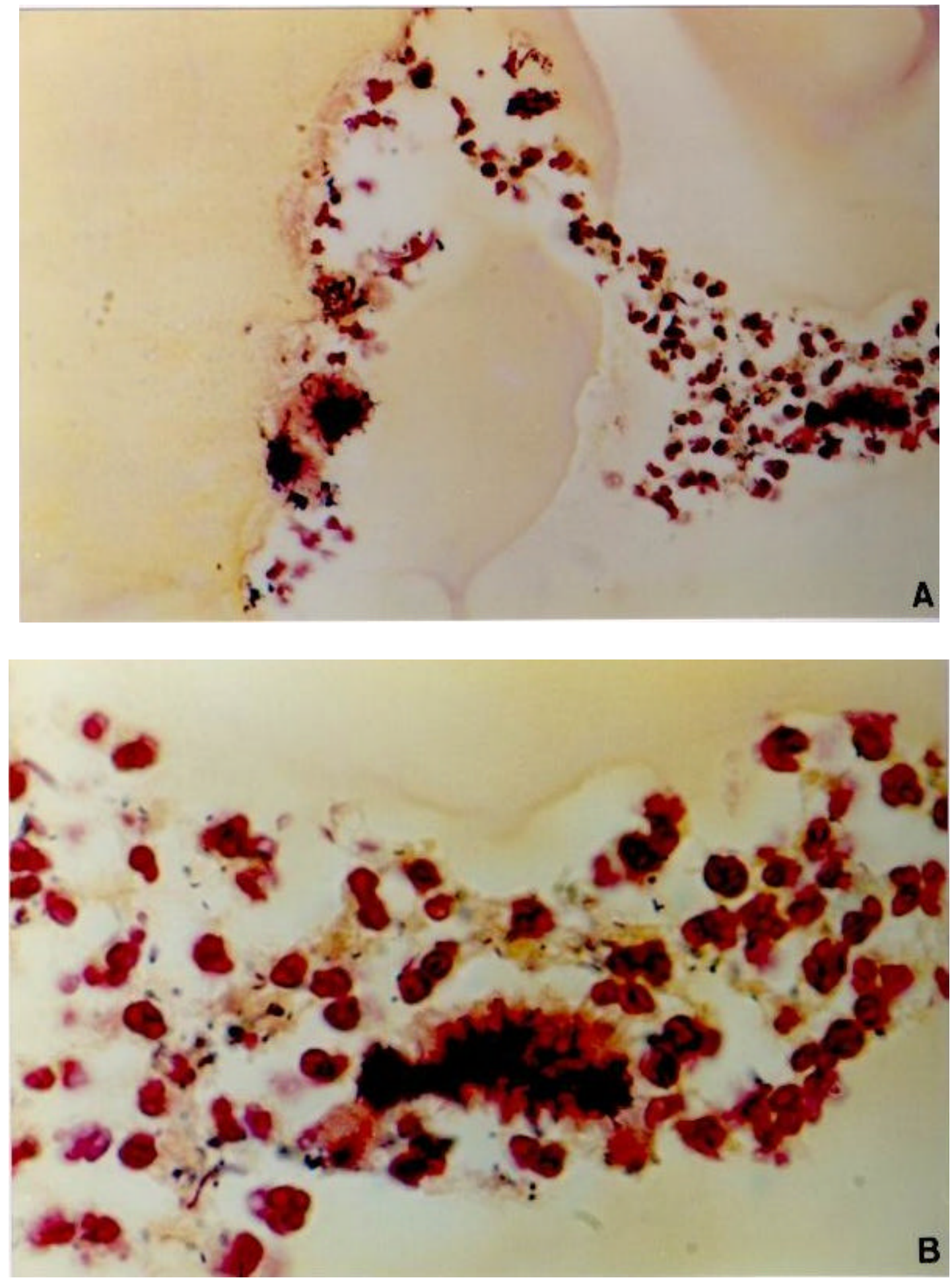

FIGURA 25 - No mesmo espécime mostrado nas figuras 22, 23 e 24, dente com necrose pulpar e granuloma apical. Na superfície apical, em áreas com reabsorção, observa-se presença de colônias bacterianas Grampositivas e Gram-negativas, e presença de células leucocitárias polimorfonucleares predominantemente. 

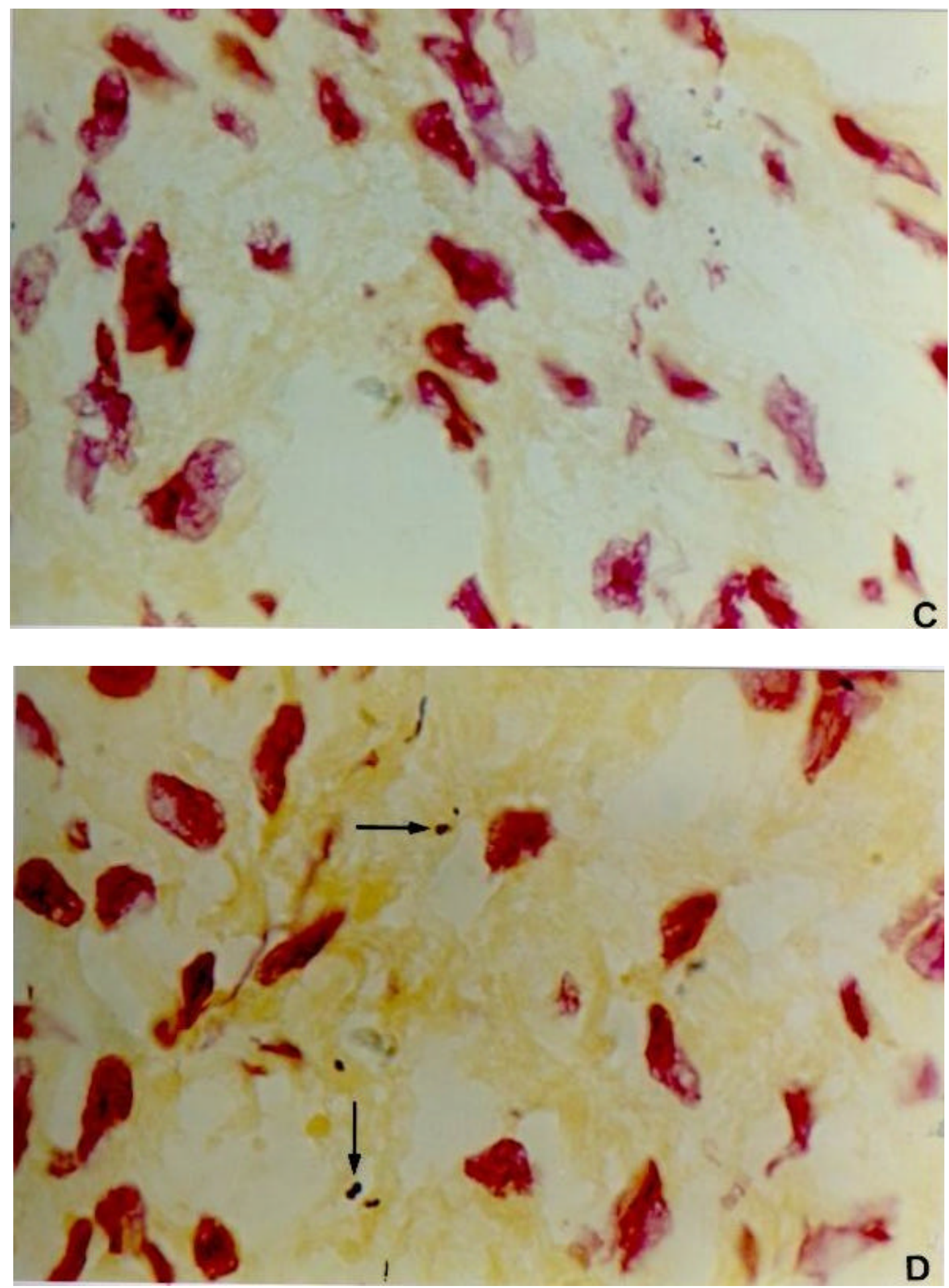

No granuloma apical contíguo, em $\mathrm{C}$ e $\mathrm{D}$, corpos bacterianos visualizados intracelularmente e no espaço intersticial (setas). (Aumento original: $\mathrm{A}=$ $160 X, B=400 X, C=400 X, D=400 X$, Brown e Brenn) 

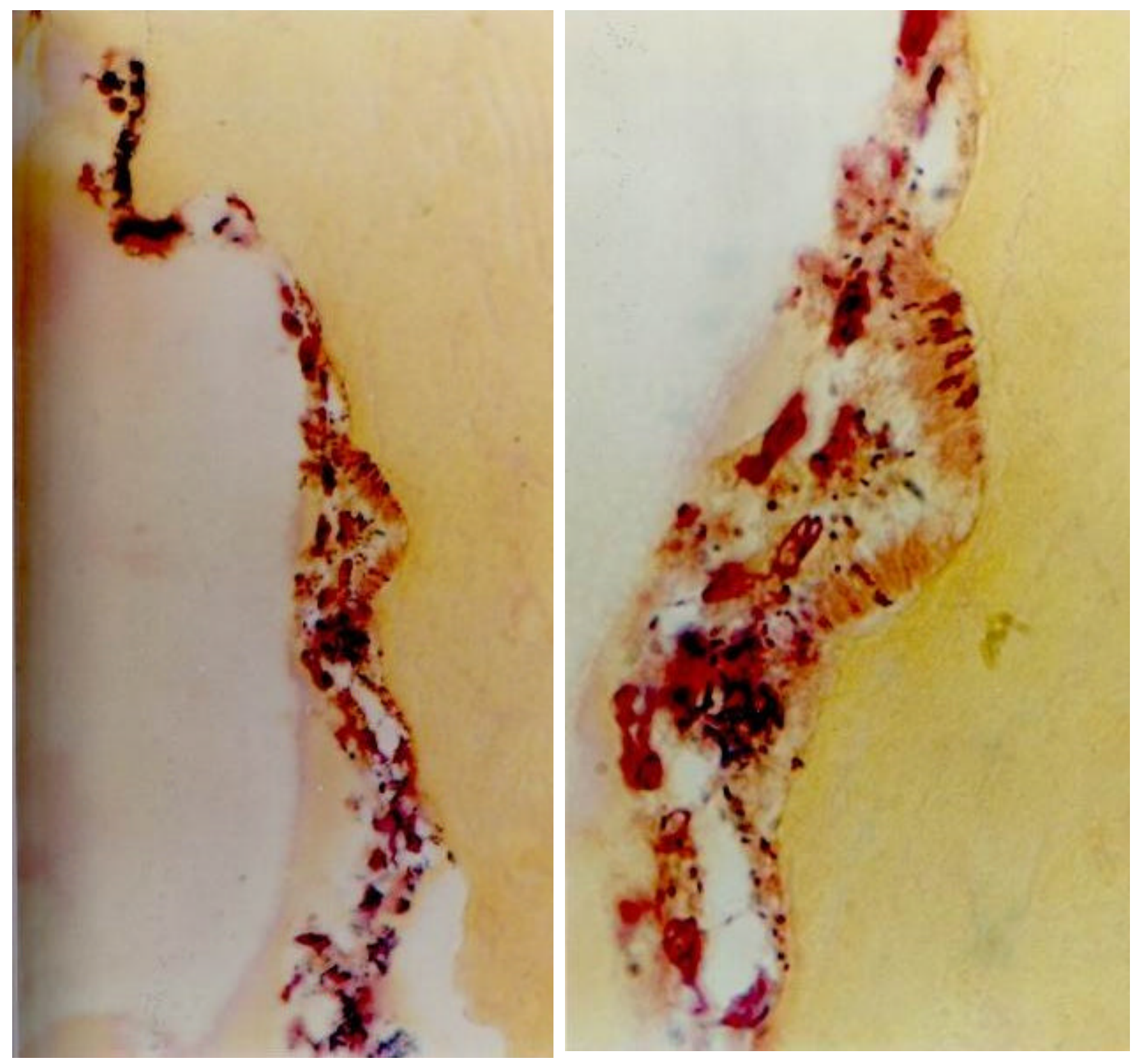

FIGURA 26 - Placa dentobacteriana apical ou biofilme apical, em dente com necrose pulpar e granuloma apical, na qual têm-se predominantemente bactérias Gram-negativas, denotadas pelos aglomerados eosinofílicos associados às bactérias Gram-positivas permeadas nas estruturas, estabelecendo uma colonização mista. Esta estrutura em placa apresentava aspecto semelhante no interior do canal radicular. (Aumento original: $\mathrm{A}=160 \mathrm{X}, \mathrm{B}=400 \mathrm{X}$, Brown e Brenn) 

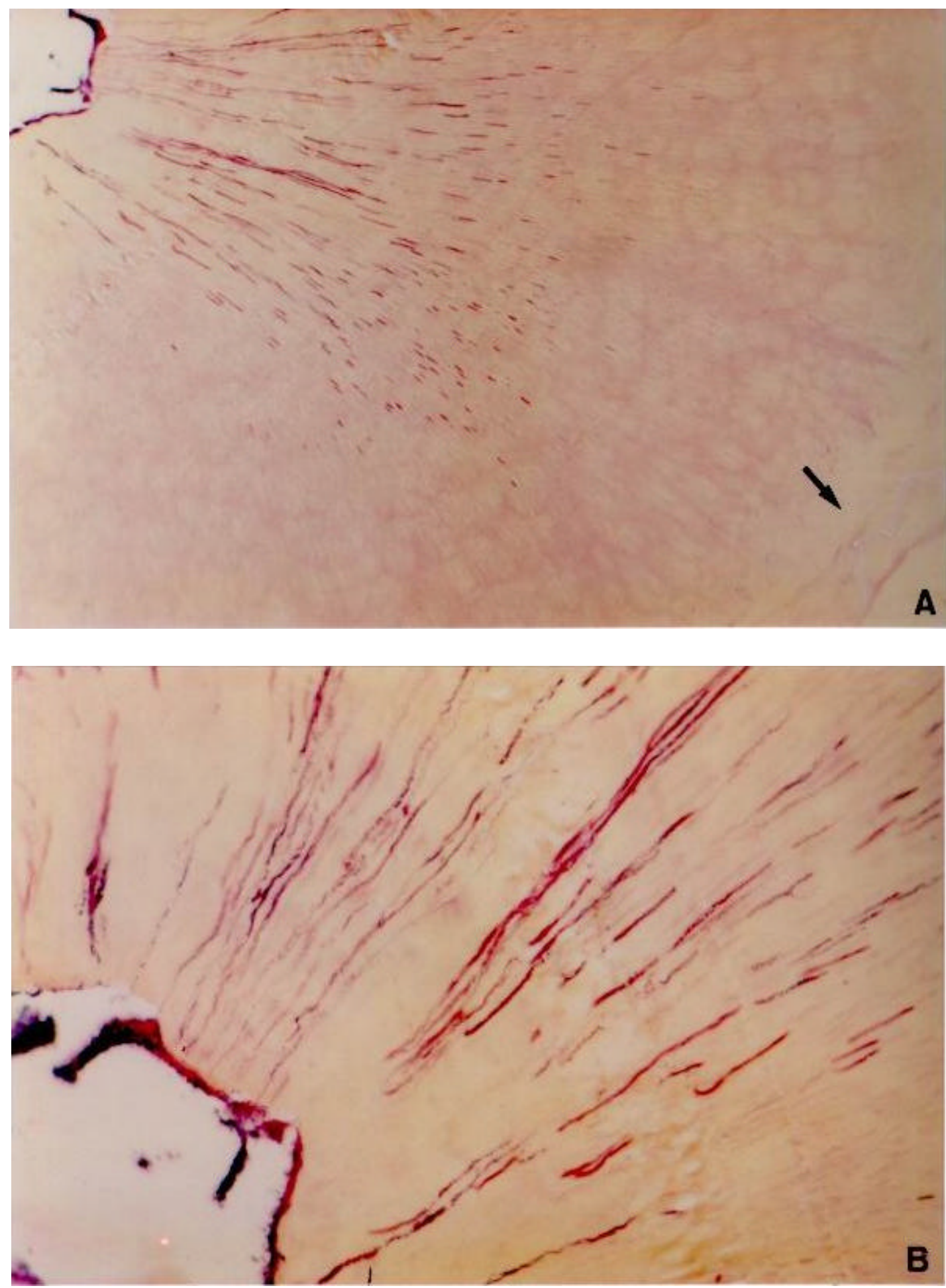

FIGURA 27 - Padrão de distribuição das bactérias, com localização intratubular na estrutura dentinária do terço apical de dente com necrose pulpar e granuloma apical. Neste dente com comprometimento do terço pulpar e médio da estrutura, como se destaca em A, observa-se a junção cementodentinária (seta). 

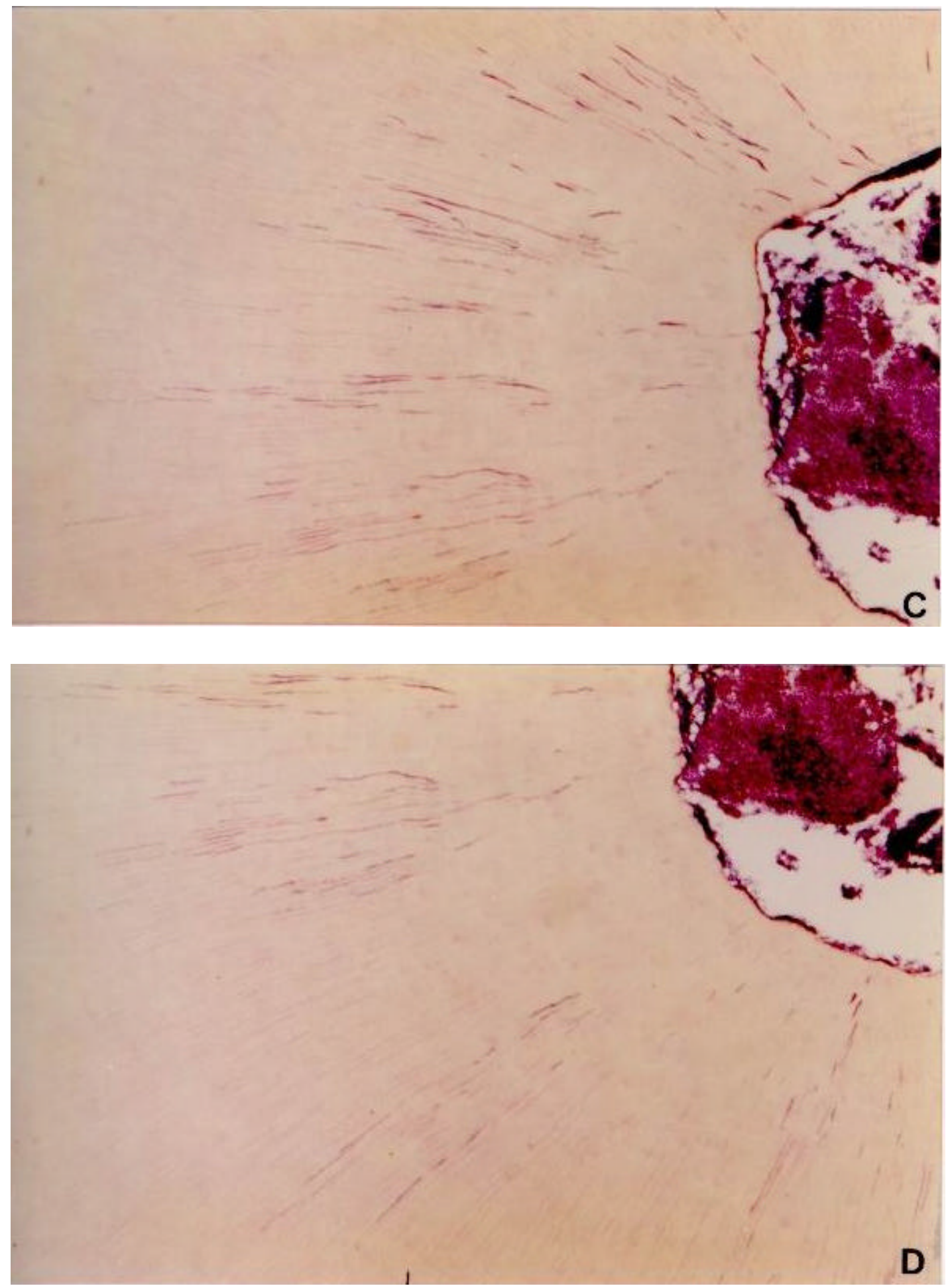

As bactérias intratubulares são predominantemente Gram-negativas. No lume, observam-se colônias livres e colonização das paredes internas do canal. (Aumento original: $\mathrm{A}=40 \mathrm{X}, \mathrm{B}=100 \mathrm{X}, \mathrm{C}=40 \mathrm{X}, \mathrm{D}=40 \mathrm{X}$, Brown e Brenn) 

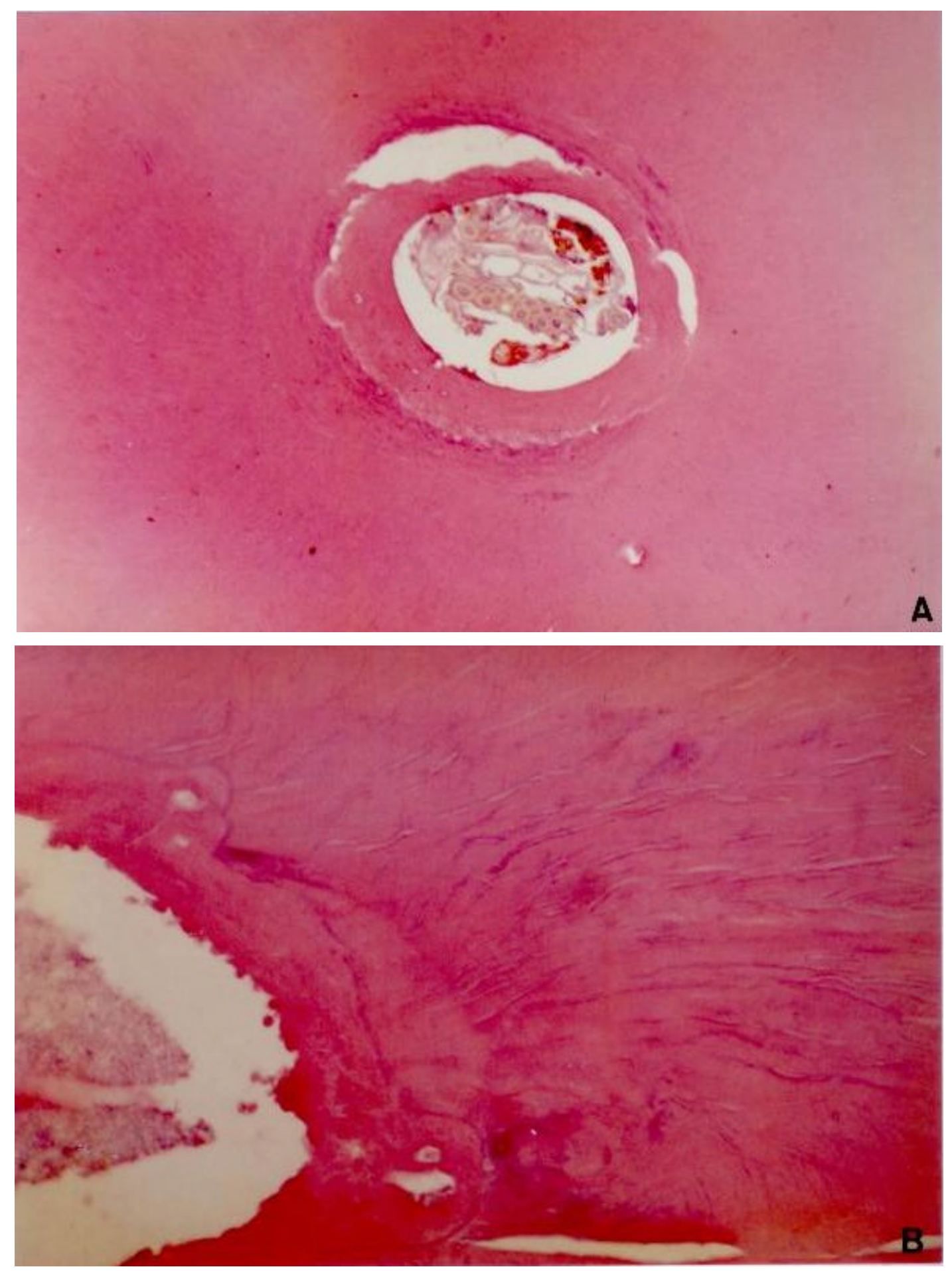

FIGURA 28 - Aspectos variados do canal radicular no terço apical de dente com necrose pulpar e granuloma apical, no qual se observa a presença de espessa camada de dentina reacional, em geral mal organizada e rica em inclusões celulares. A junção desta dentina rapidamente formada, com a dentina criteriosamente estabelecida, gera planos de clivagem e irregularidades $(\mathrm{A}, \mathrm{B}, \mathrm{C})$. 

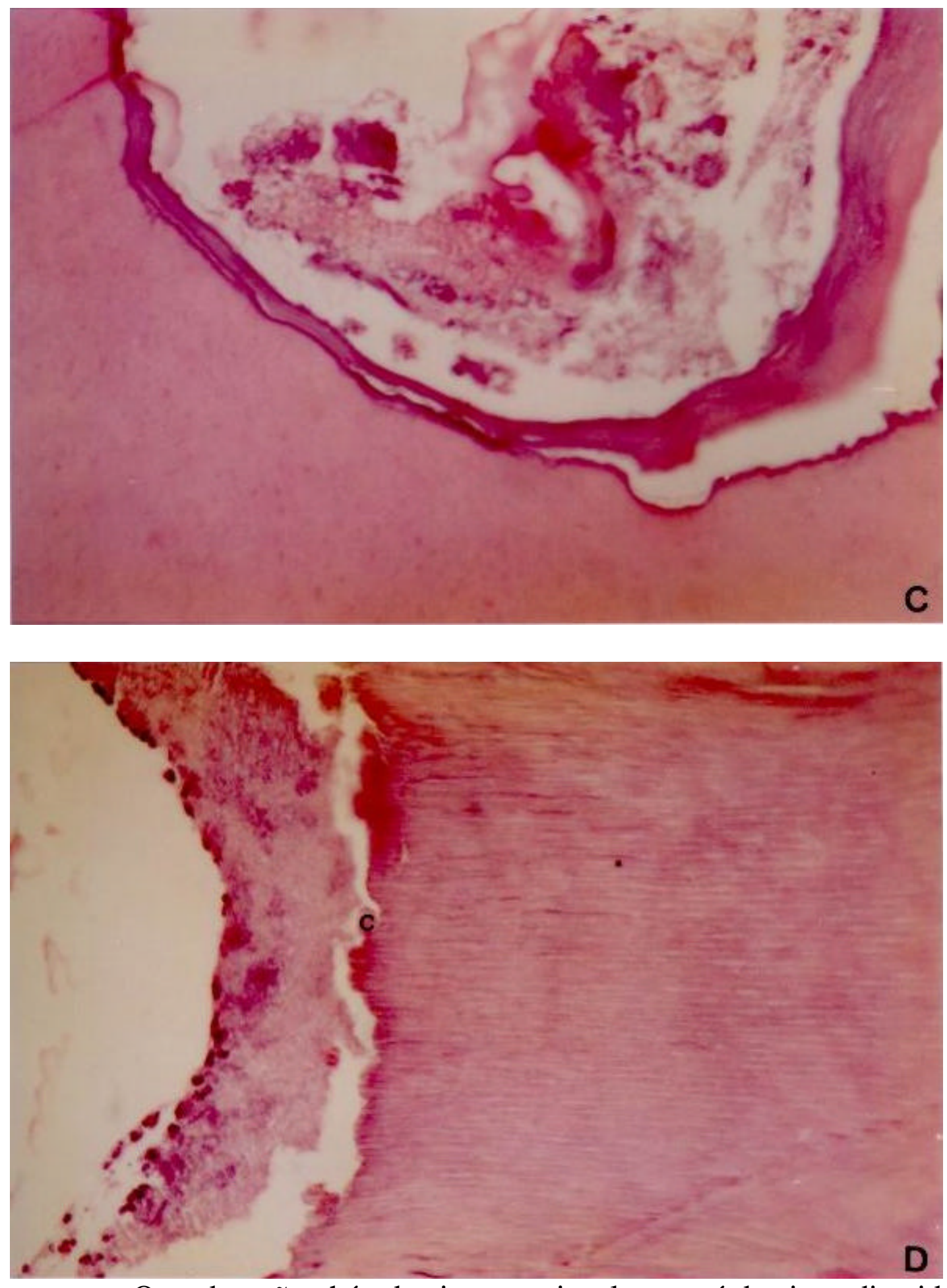

Quando não há dentina reacional a pré-dentina digerida, as calcosferitas (c) e os túbulos dentinários ficam francamente expostos às colônias bacterianas do lume, como se vê em D. (Aumento original: $\mathrm{A}=40 \mathrm{X}, \mathrm{B}, \mathrm{C}$ e $\mathrm{D}=$ 100X, H.E.) 

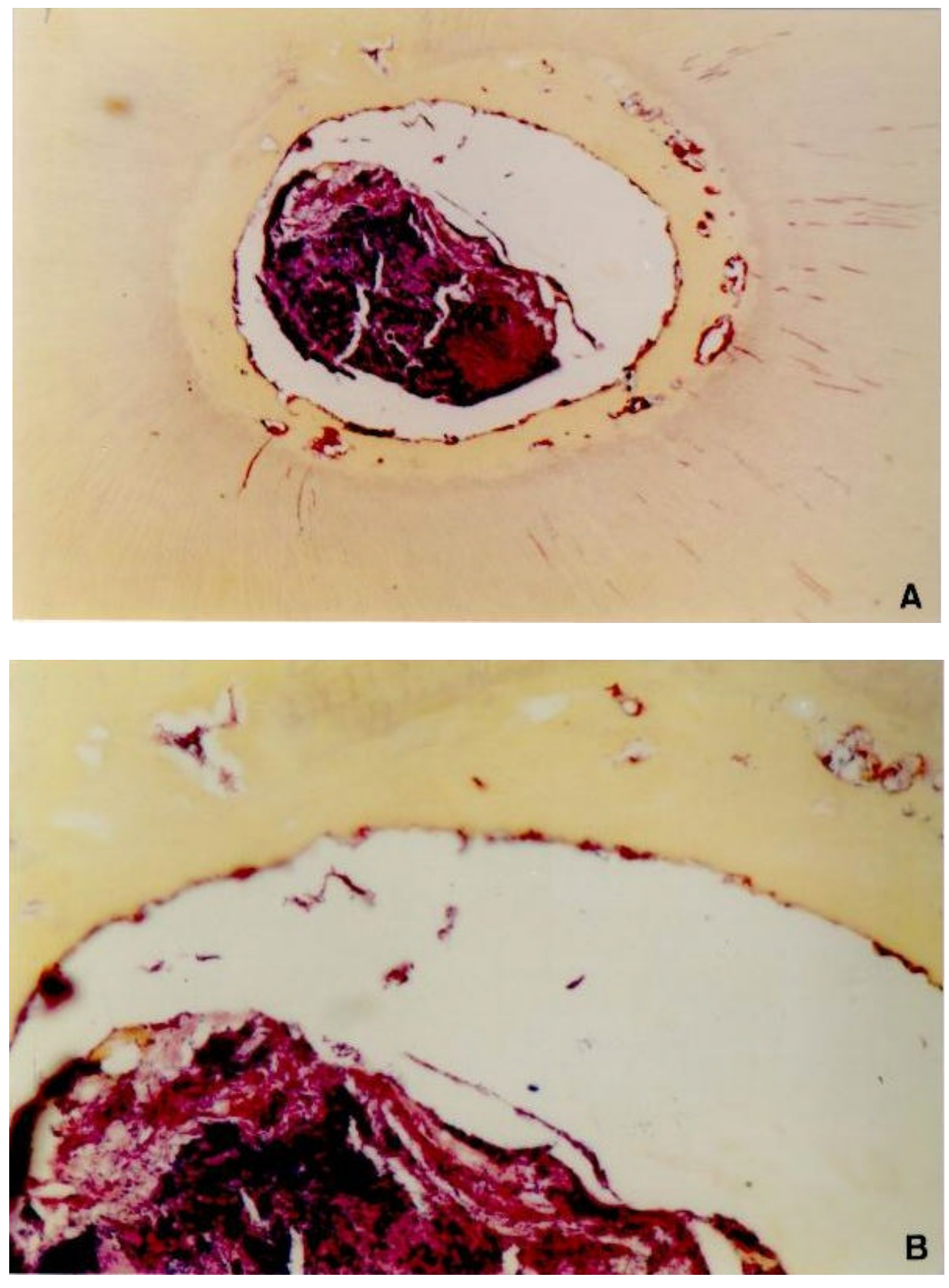

FIGURA 29 - Canal radicular de dente com necrose pulpar e granuloma apical, cortados transversalmente no terço apical. A estrutura da dentina reacional, mais precisamente nos locais de antigas inclusões celulares e irregularidades, acha-se totalmente permeada por bactérias e colônias Gram-negativas e Gram-positivas (A e B). 

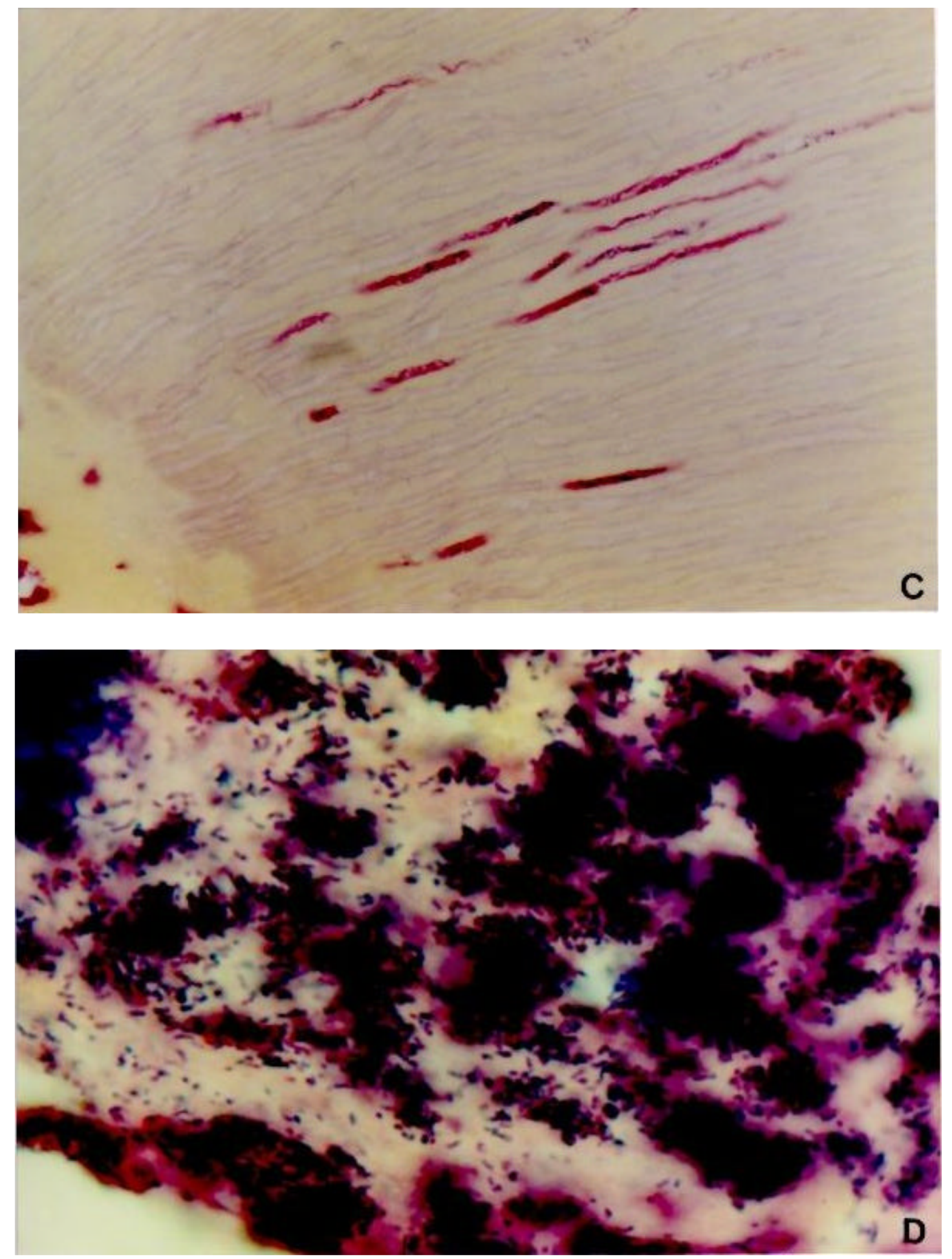

Nos túbulos dentinários e no lume, as bactérias também revelaram-se abundantes. Em D, observa-se grande quantidade de bactérias Gram-positivas e Gram-negativas no lume do canal. (Aumento original: $\mathrm{A}=40 \mathrm{X}, \mathrm{B}=100 \mathrm{X}, \mathrm{C}=$ $160 X, D=400 X$, Brown e Brenn) 

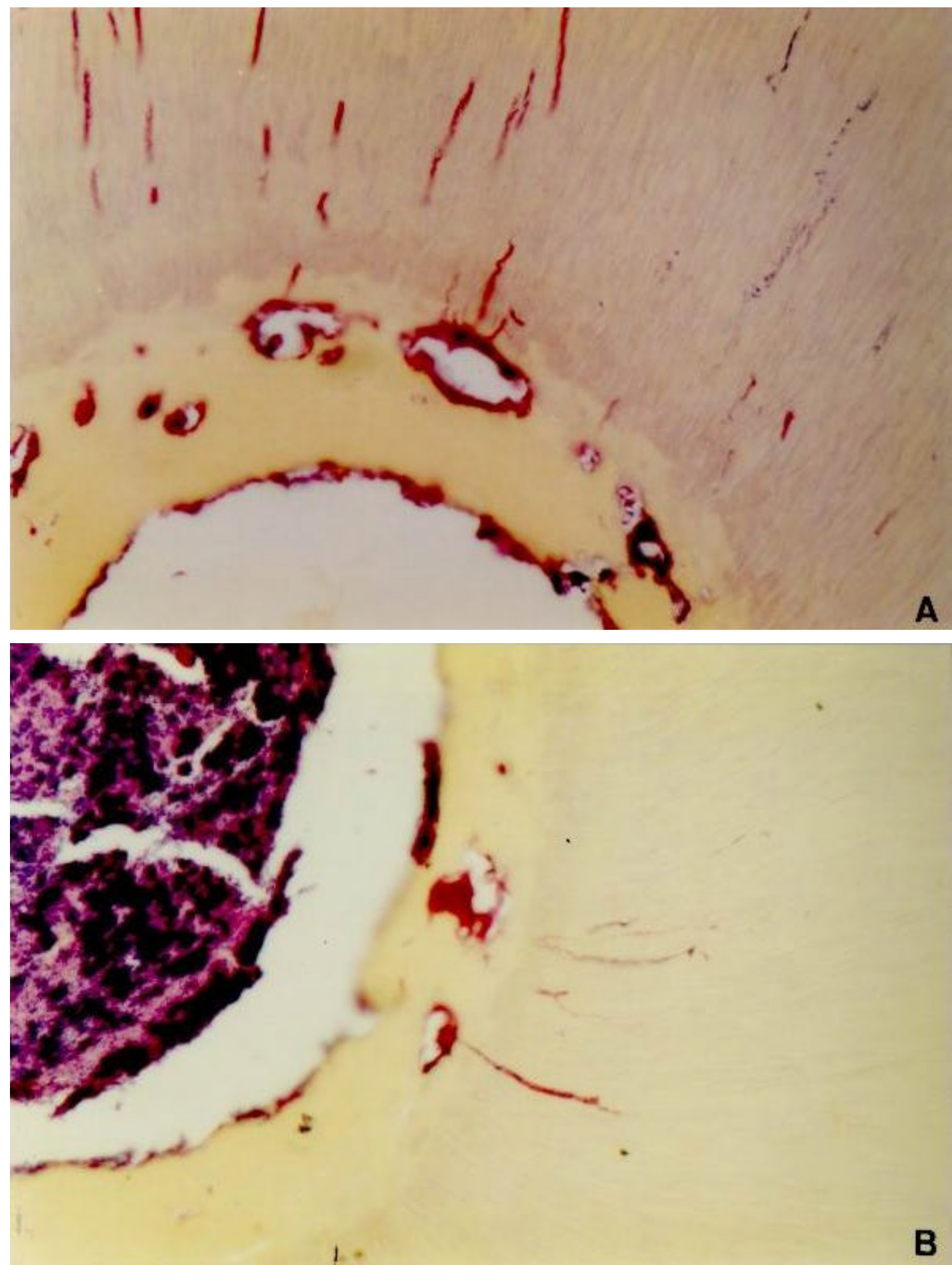

FIGURA 30 - No mesmo espécime da figura 29, dente com necrose pulpar e granuloma apical. 

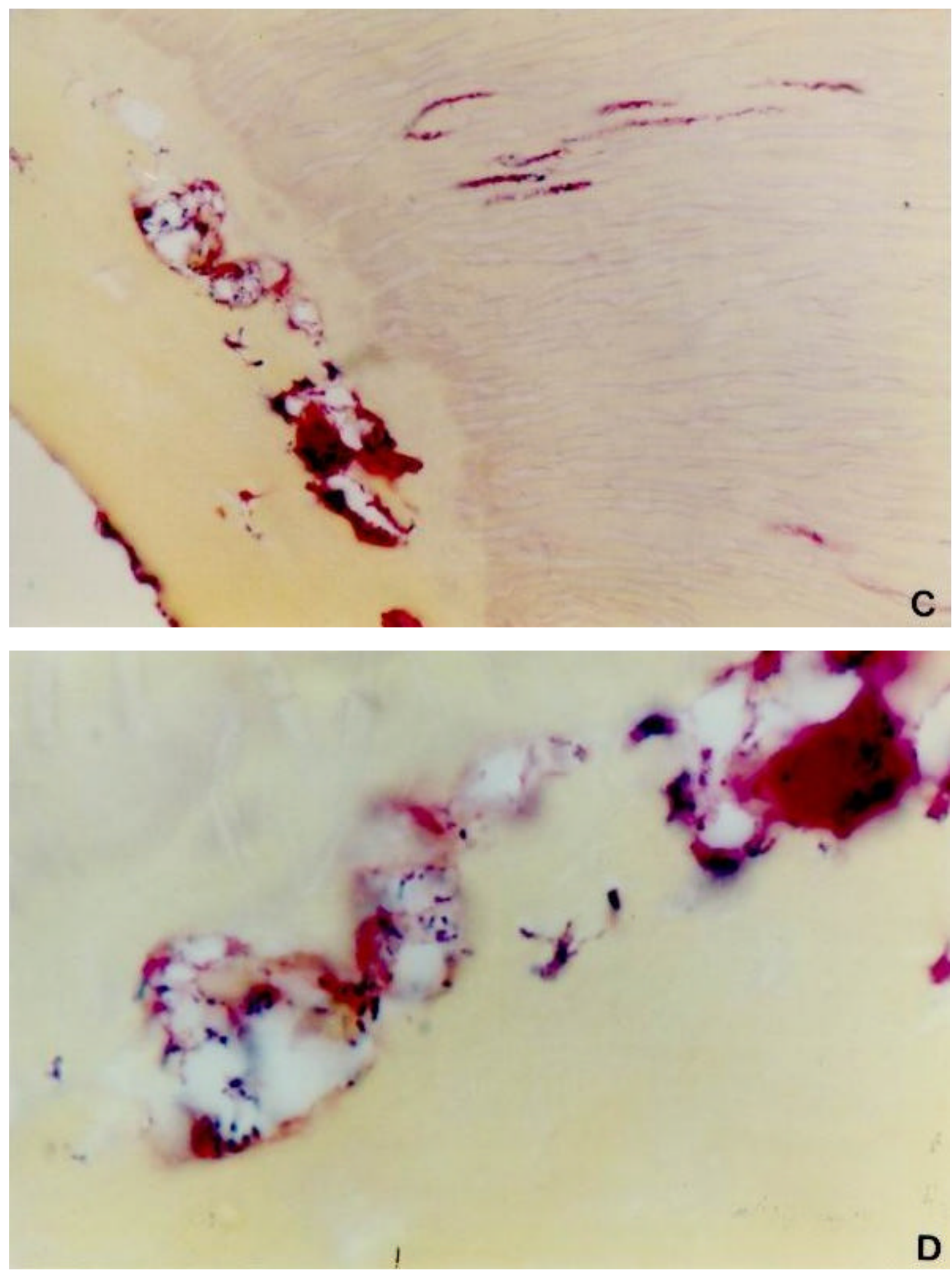

Com maior detalhe, observa-se a colonização da parede interna do canal e a presença de bactérias Gram-negativas, predominantemente nas áreas de antigas inclusões celulares e nos túbulos dentinários. (Aumento original: $\mathrm{A}$ e $\mathrm{B}=$ $100 X, C=160 X, D=400 X$, Brown e Brenn) 

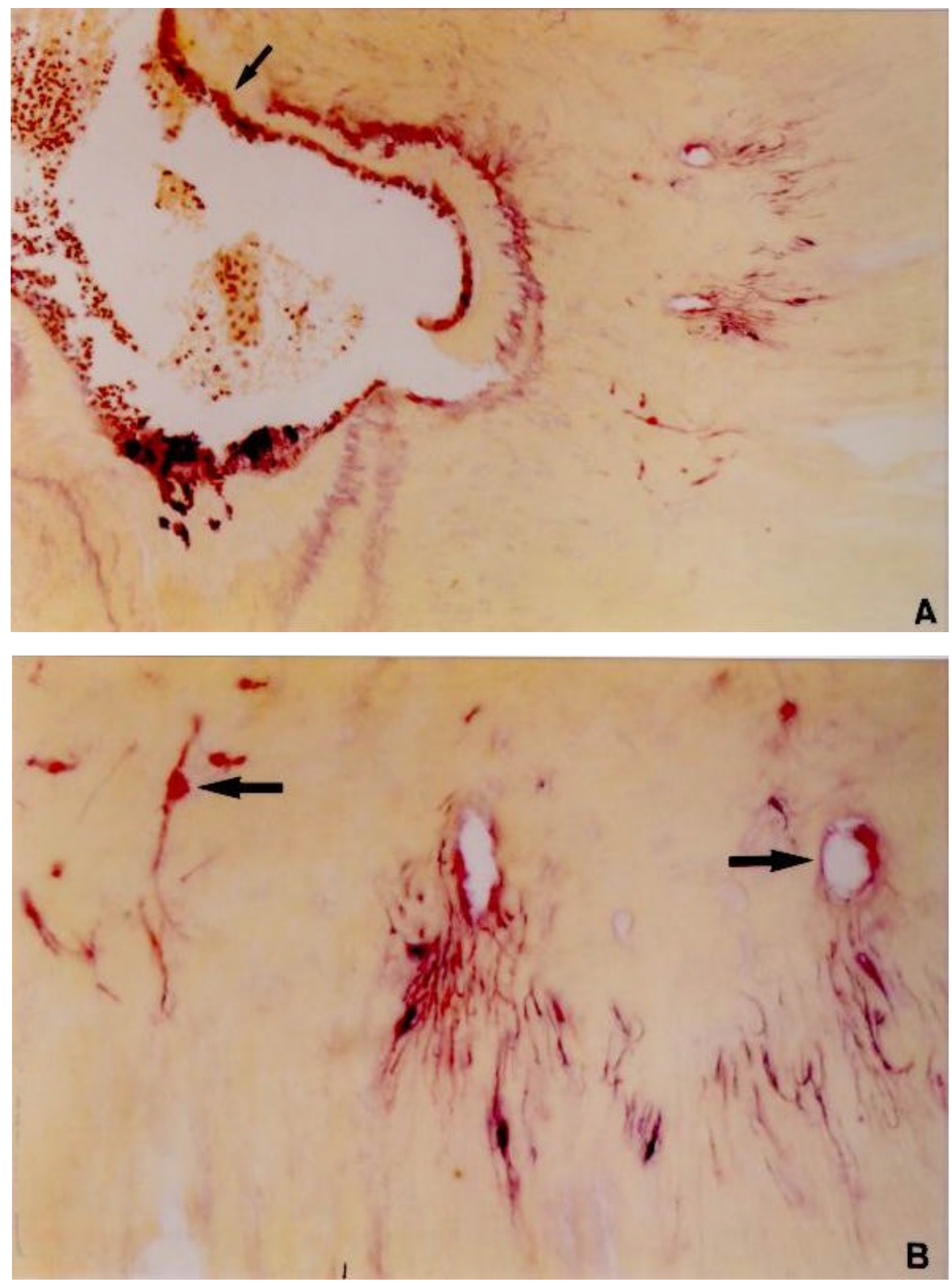

FIGURA 31 - Dente com necrose pulpar e granuloma apical, terço apical cortado transversalmente, no qual se vêem colonização bacteriana da parede interna (seta), dentina reacional e canais acessórios minúsculos, a partir dos quais se observam múltiplos túbulos dentinários infiltrados por bactérias. 

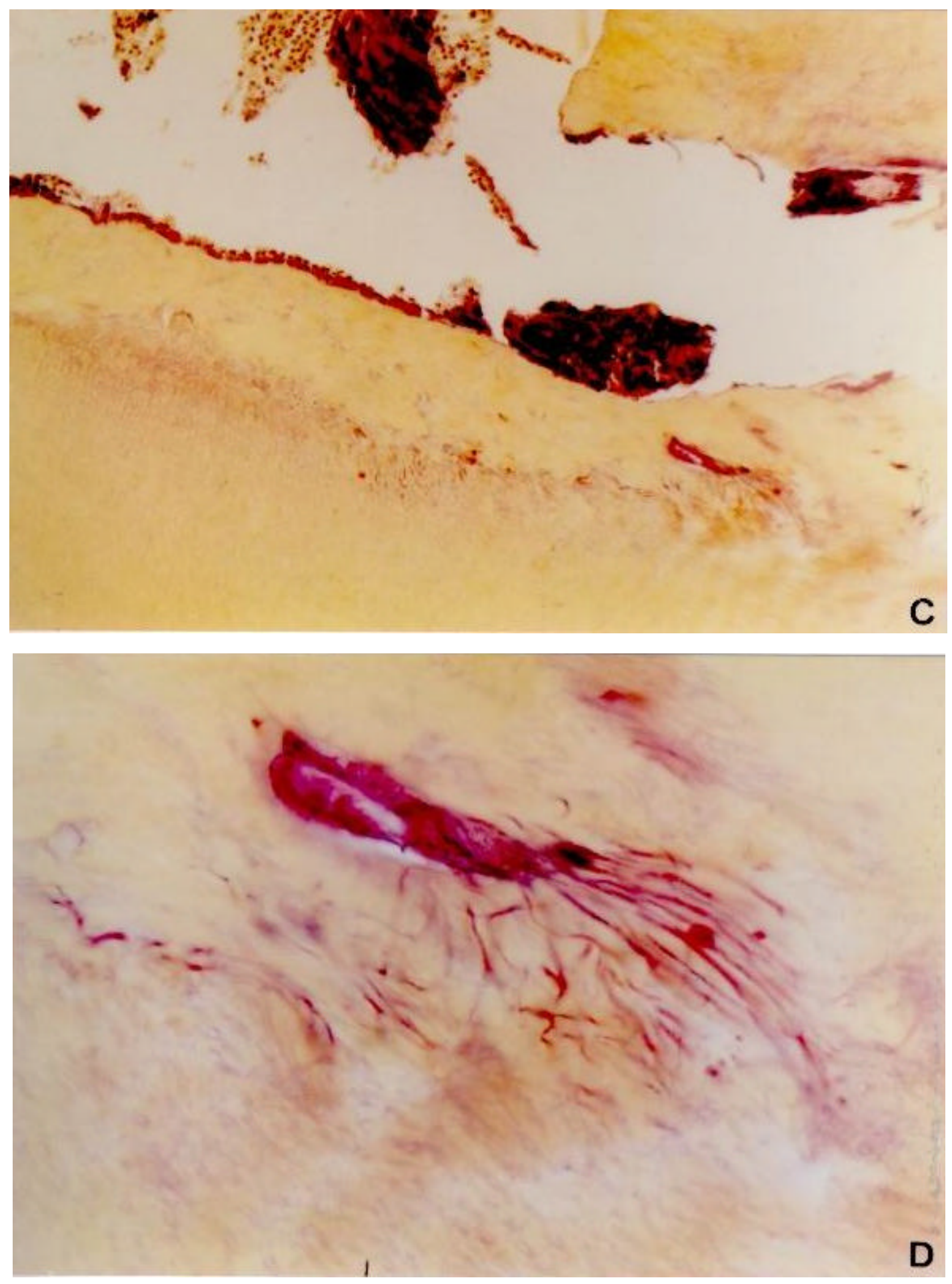

Em A e B observam-se áreas de inclusões celulares, preenchidas por bactérias Gram-negativas (setas maiores). (Aumento original: $\mathrm{A}=40 \mathrm{X}, \mathrm{B}=100 \mathrm{X}, \mathrm{C}$ $=40 X, \mathrm{D}=160 \mathrm{X}$, Brown e Brenn) 


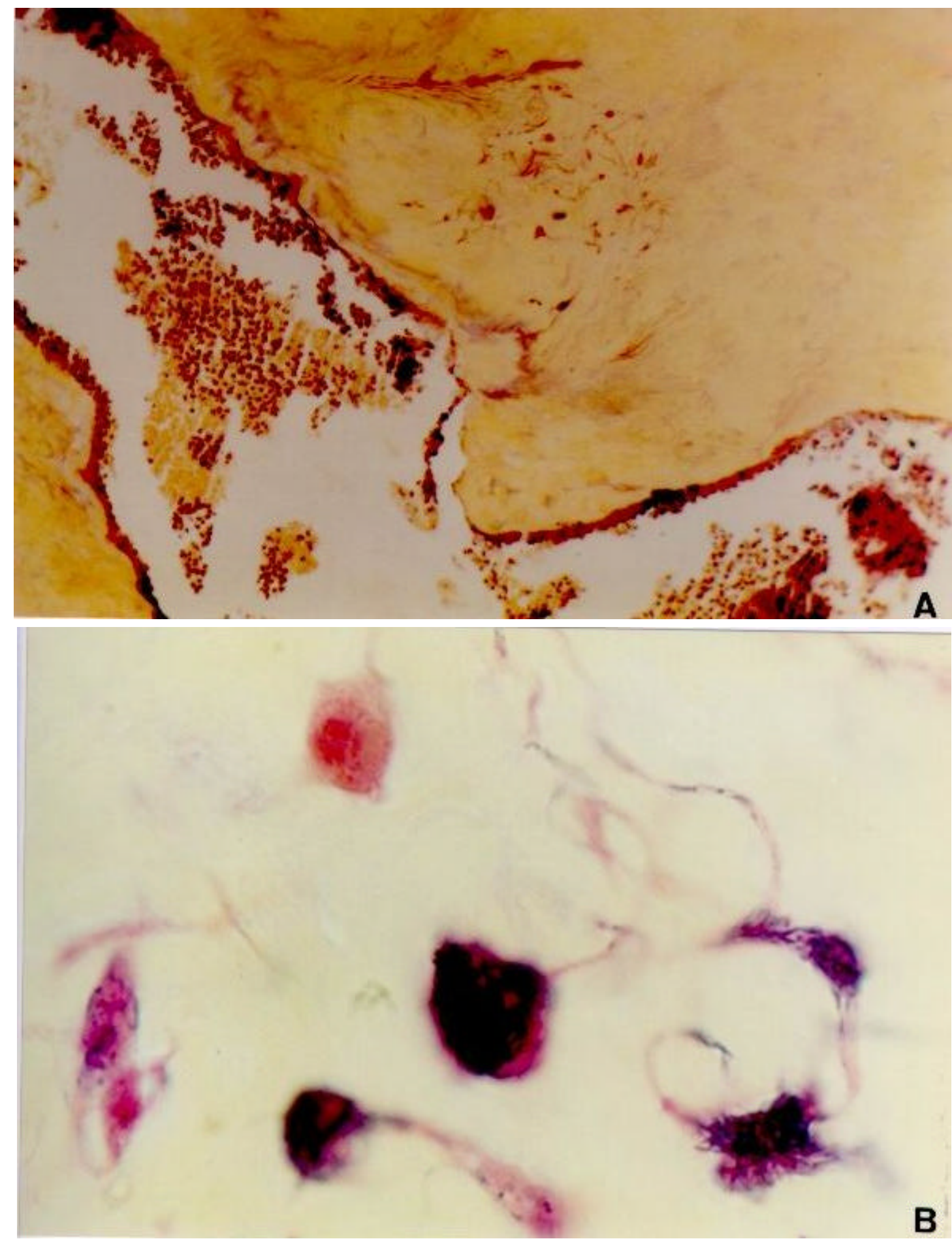

FIGURA 32 - Na região de dentina reacional observam-se dentinoplastos preenchidos por bactérias Gram-positivas e Gram-negativas (setas), o mesmo ocorrendo nos túbulos dentinários. No lume e nas paredes internas do canal radicular têm-se colônias bacterianas Gram-positivas e Gram-negativas. (Aumento original: $\mathrm{A}=40 \mathrm{X}, \mathrm{B}=400 \mathrm{X}$, Brown e Brenn) 

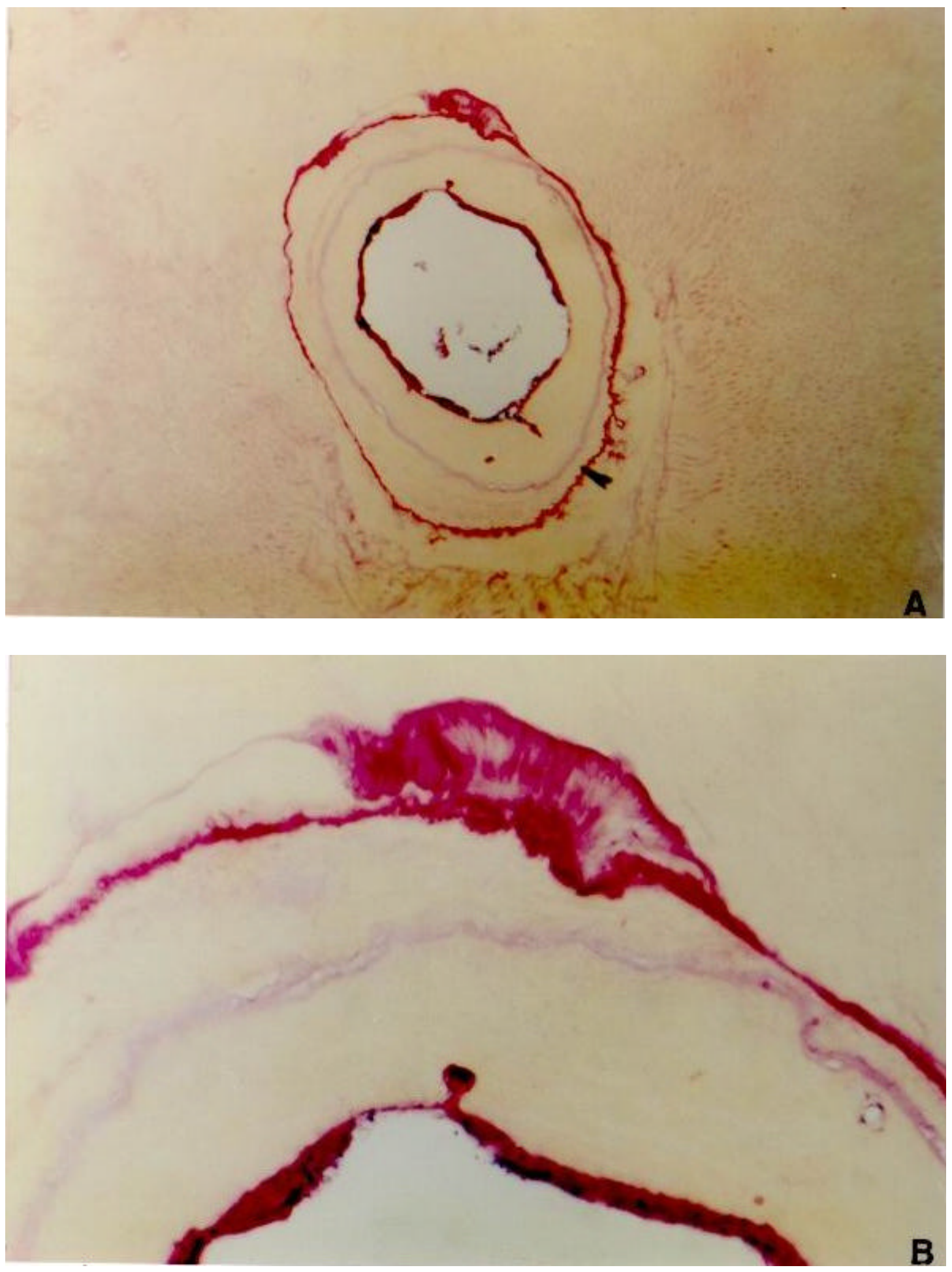

FIGURA 33 - Dentina reacional depositada concentricamente, em camadas irregulares e justapostas, em dente com necrose pulpar e granuloma apical. 

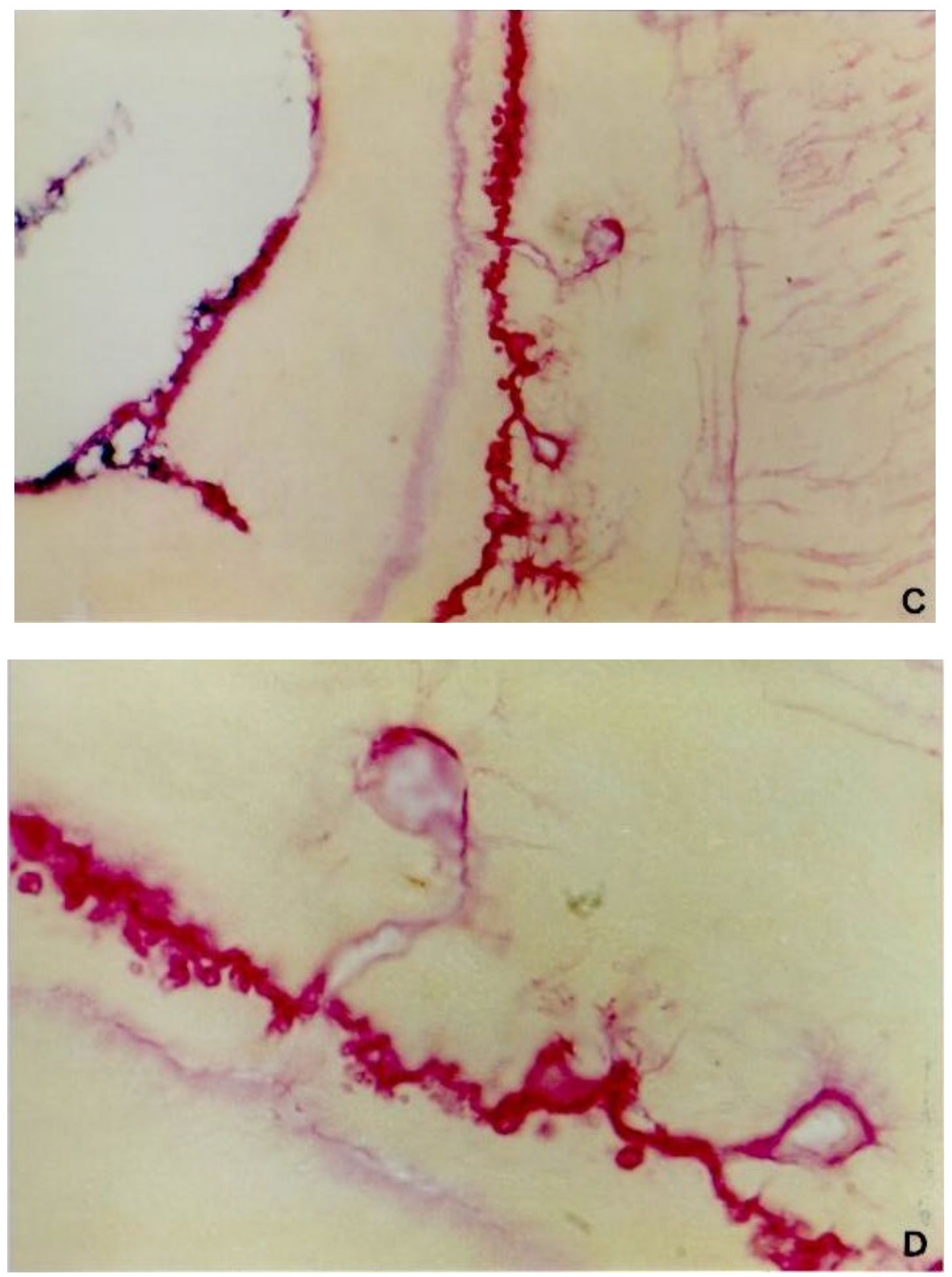

Nas irregularidades das interfaces das camadas concêntricas de dentina reacional, bactérias predominantemente Gram-negativas invadem e se incorporam, formando verdadeiras colônias de difícil comprometimento por substâncias químicas e mesmo técnica de instrumentação endodôntica. (Aumento original: $\mathrm{A}=40 \mathrm{X}, \mathrm{B}$ e $\mathrm{C}=160 \mathrm{X}, \mathrm{D}=400 \mathrm{X}$, Brown e Brenn) 

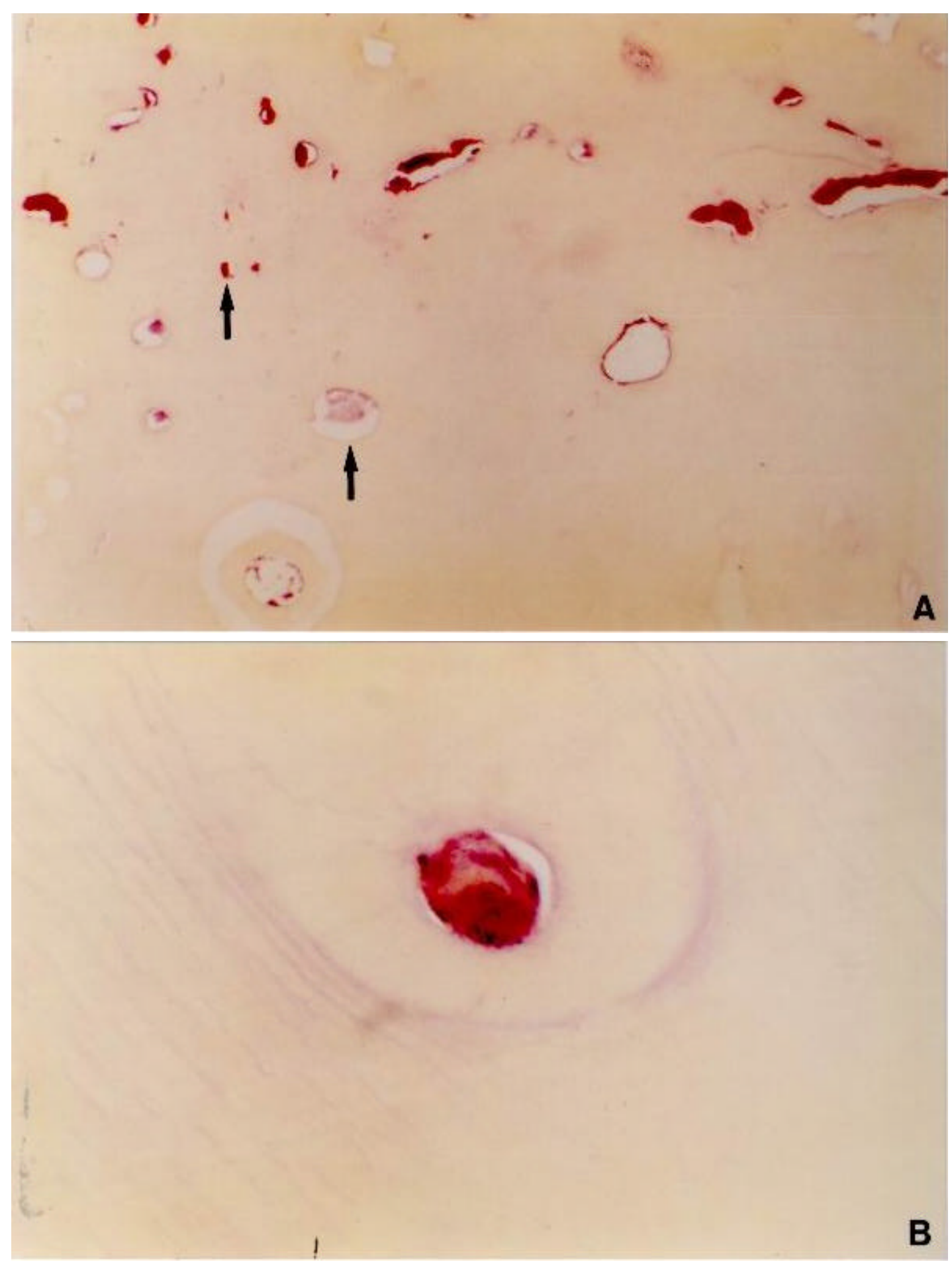

FIGURA 34 - Delta apical de dente com necrose pulpar e granuloma apical com cemento rico em cementoplastos. Em A e B tem-se a presença de muitas colônias bacterianas Gram-negativas nos canais acessórios e cementoplastos (setas). 

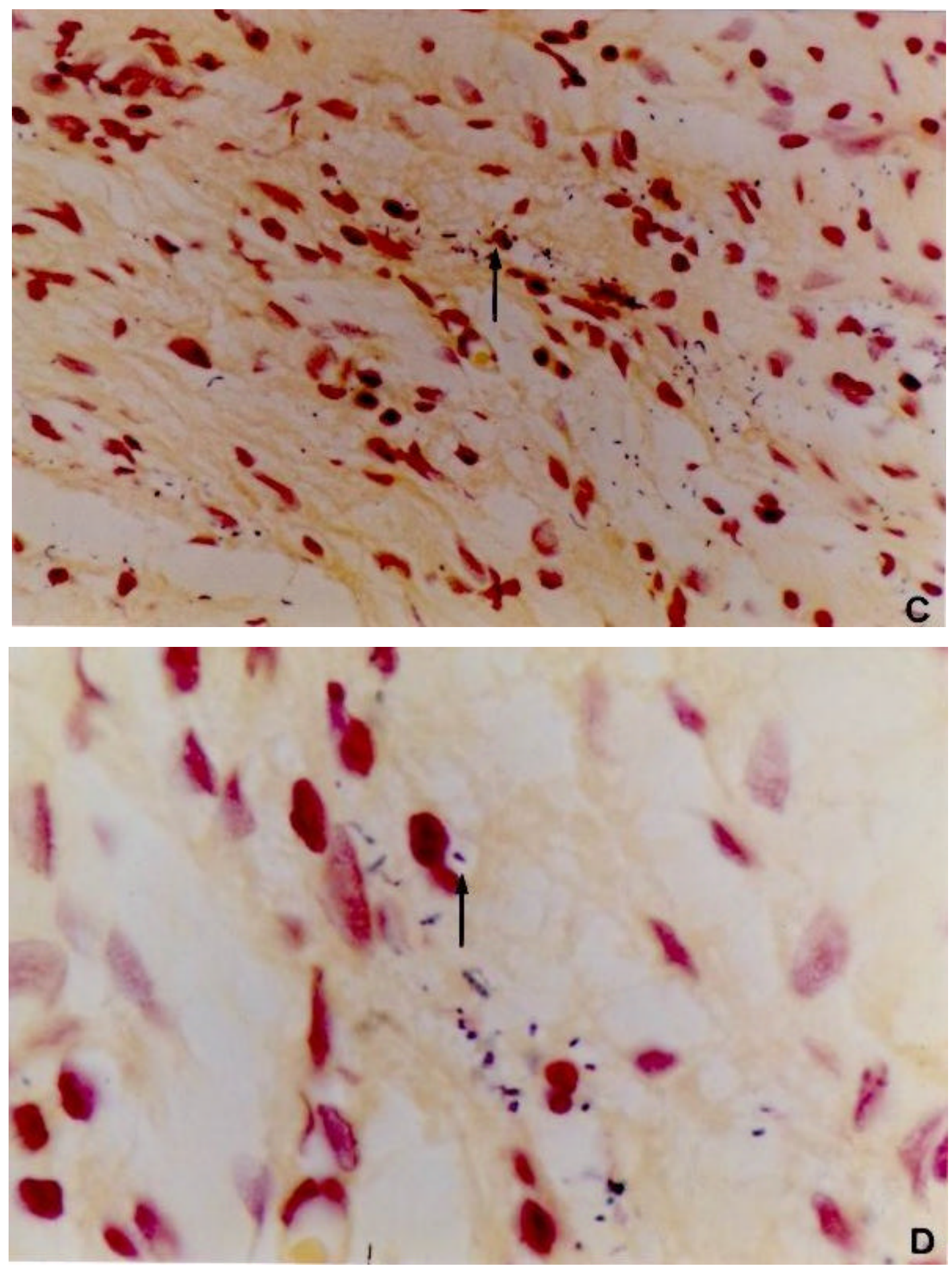

No granuloma contíguo, presença de bactérias em vacúolos citoplasmáticos de macrófagos e neutrófilos, bem como no espaço intersticial (setas). (Aumento original: $\mathrm{A}=40 \mathrm{X}, \mathrm{B}=400 \mathrm{X}, \mathrm{C}=160 \mathrm{X}, \mathrm{D}=400 \mathrm{X}$, Brown e Brenn) 

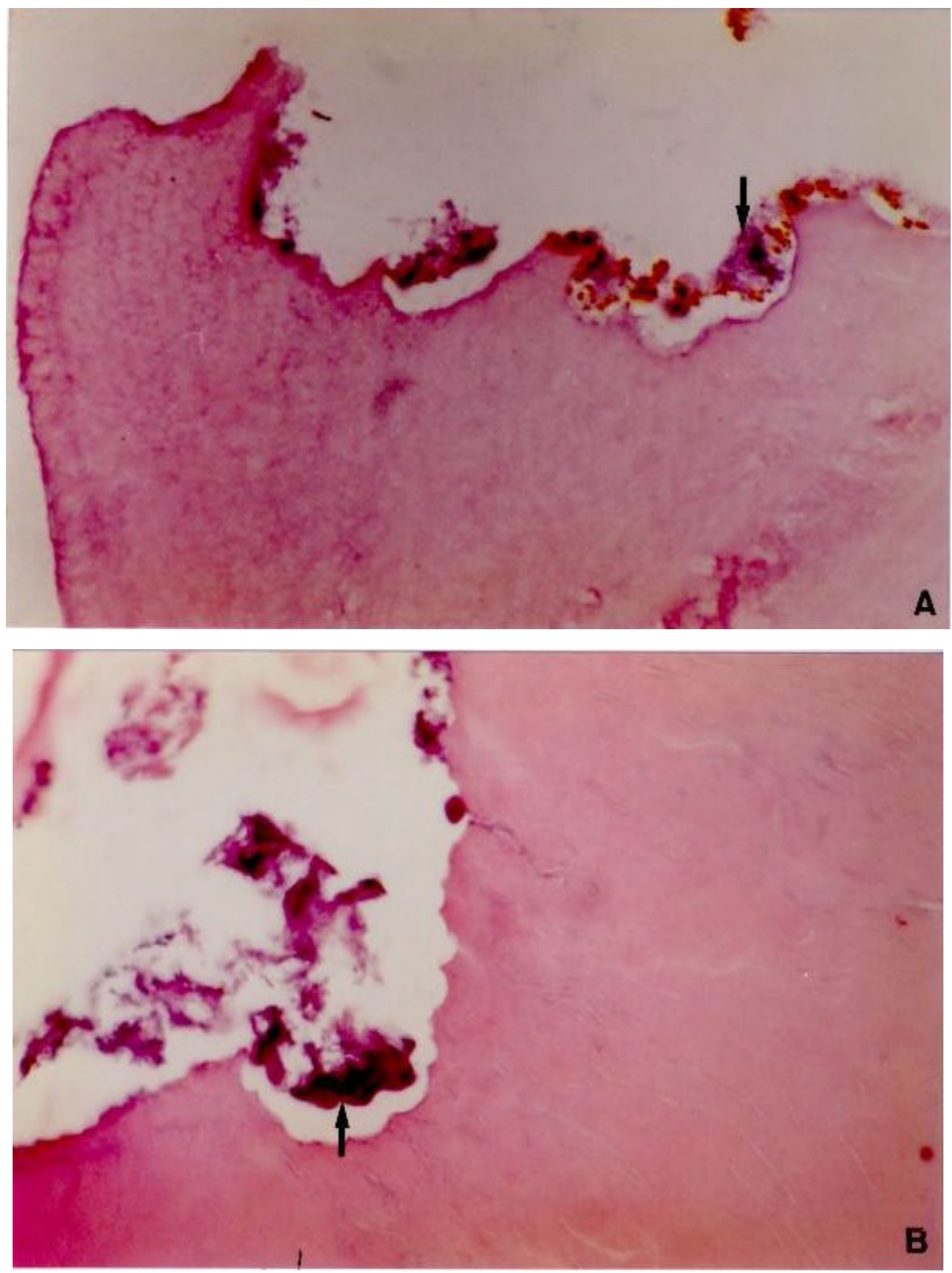

FIGURA 35 - Lacunas de Howship encontradas na superfície apical de dente com necrose pulpar e granuloma apical, cujas lacunas foram colonizadas por bactérias e preenchidas por placas dentobacterianas (setas). 

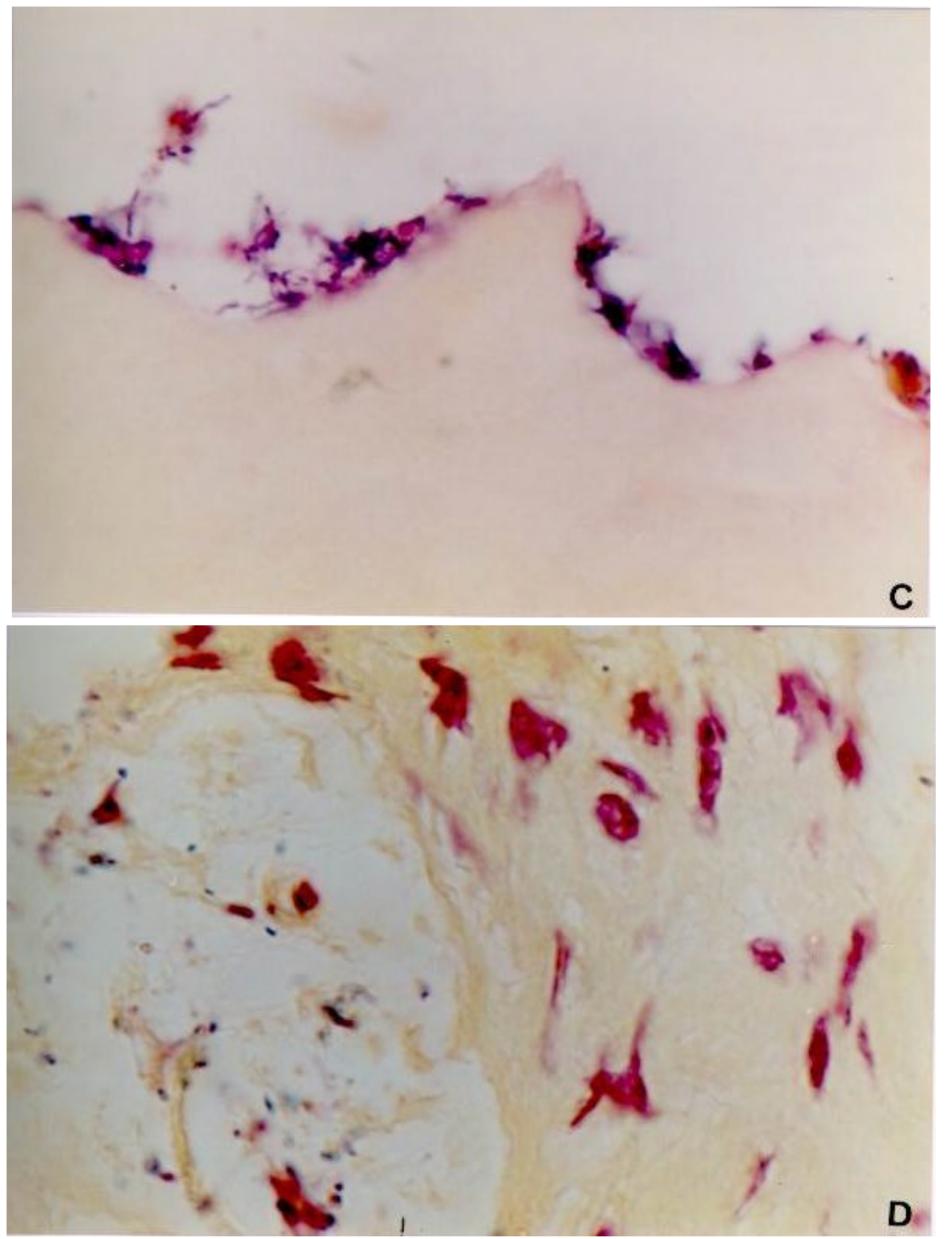

No granuloma apical contíguo, presença de muitas bactérias no espaço intersticial. (Aumento original: $\mathrm{A}=160 \mathrm{X}, \mathrm{B}=100 \mathrm{X}, \mathrm{H} . \mathrm{E}$; $\mathrm{C}=160 \mathrm{X}, \mathrm{D}=$ 400X, Brown e Brenn) 


\section{3 - Grupo C - Granulomas apicais}

Os cortes microscópicos neste grupo mostraram a organização do infiltrado inflamatório e dos componentes teciduais, variando de acordo com o grau de maturação da lesão.

\subsection{1 - Observações relativas ao granuloma apical (Figura 36)}

$\mathrm{Na}$ maioria dos espécimes, os granulomas apresentavam-se segmentados, devido ao ato cirúrgico. Observaram-se com frequiência depósitos esféricos hialinos no interior de plasmócitos, representando agregados de imunoglobulina sintetizada no retículo endoplasmático rugoso da célula, chamados de corpúsculo de Russel (Figura 37). Notaram-se ainda restos epiteliais de Malassez, representados por cordões ou por ilhas de células epiteliais, distribuídos ao acaso no interior da lesão.

Com grande frequiência, observaram-se também células pseudoxantomatosas, cujos aspectos morfólogicos, de vacuolação e núcleo rechaçado para a periferia, permitiram identificá-las.

Em cinco espécimes, os granulomas foram relacionados aos extravasamentos de material de baixo potencial imunogênico. Por isso os fenômenos celulares apresentavam-se não tão exuberantes. 
Em grande parte das amostras observaram-se bactérias Grampositivas isoladas no interior dos granulomas ora localizadas nos espaços extracelulares, ora no interior de células macrofágicas. O oposto ocorreu em relação às colônias bacterianas, sendo somente notadas em três espécimes do grupo, com localização periférica à lesão. 


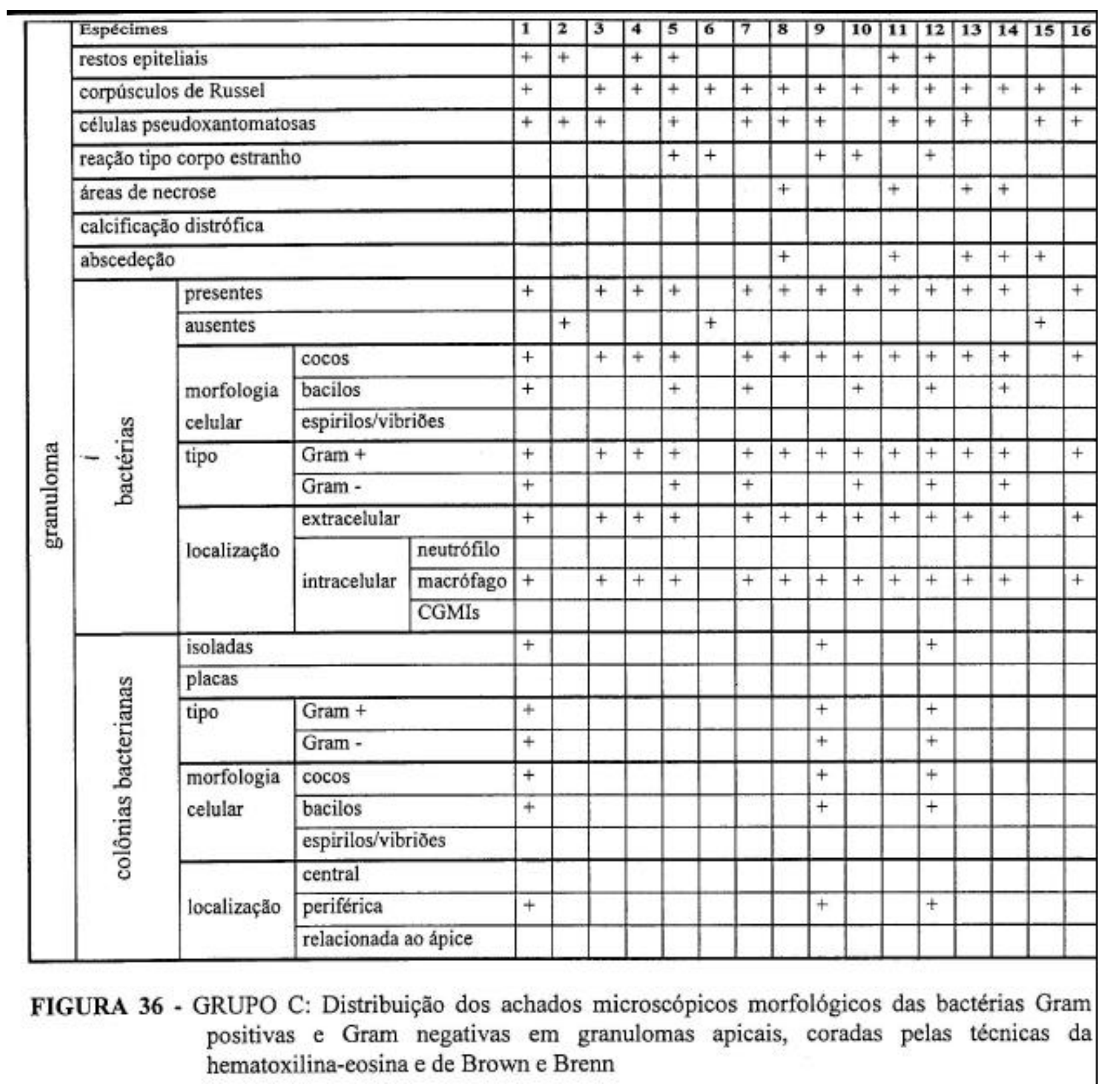



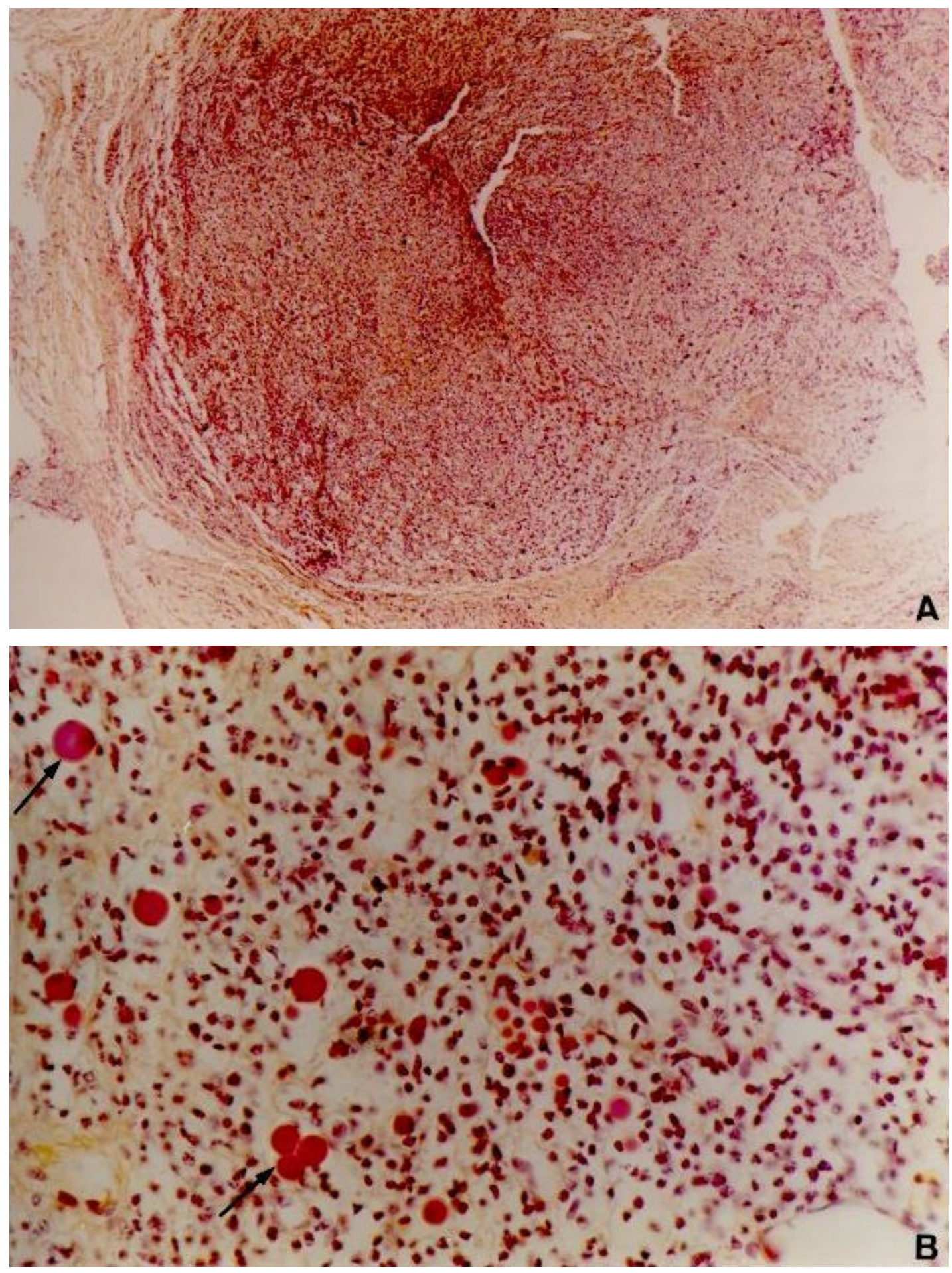

FIGURA 37 - Granuloma apical isoladamente examinado, quanto à sua raiz de origem, onde predominantemente se encontram macrófagos, linfócitos, plasmócitos e muitos corpúsculos hialinos de Russel (setas). Bactérias isoladas foram encontradas em vacúolos intracelulares. (Aumento original: $\mathrm{A}=10 \mathrm{X}, \mathrm{B}=40 \mathrm{X}$, Brown e Brenn) 
6 - DISCUSSÃO 


\title{
6 - DISCUSSÃO
}

\begin{abstract}
A Endodontia sofreu profundas modificações a partir 1894, quando MILLER $^{64}$ evidenciou pela primeira vez bactérias em polpas necróticas de dentes humanos, correlacionando-as como o principal agente etiológico das doenças pulpares. Desde então, várias técnicas foram desenvolvidas com o objetivo de estudar a microbiota dos canais radiculares, como também a sua participação no desenvolvimento das doenças periapicais.
\end{abstract}

Para avaliar a importância da bactéria no desenvolvimento das doenças pulpares, KAKEHASHI; STANLEY; FITZGERALD ${ }^{48}$ expuseram polpas dentárias de ratos convencionais e "germ-free" à microbiota bucal, nas quais os resultados revelaram desenvolvimento de lesões pulpares e periapicais nos animais convencionais, ao passo que nos "germ-free" as polpas dentárias mantiveram-se vitais.

A microbiota dos canais radiculares tem sido avaliada por diferentes métodos, como a cultura ${ }^{1,6,7,15,23,26,30,43,51,60,64,65,83,94,99,111,113}$, microscopia de contraste de fase ou de campo escuro ${ }^{15,26}$, microscopia eletrônica ${ }^{30,67,68,69,92,94,102}$, técnica da imunofluorescência indireta ${ }^{5,11}$ e microscopia óptica empregando a técnica de Brown e Brenn ${ }^{1,11,20,39,48,57,59,67,68,73,75,76,106}$.

Os diferentes resultados observados em culturas, provavelmente estejam relacionados aos passos técnicos, como obtenção das amostras, meio de transporte, cultura em aerobiose apenas e tempo de incubação. 
O risco de contaminação na fase de obtenção dos espécimes tem sido bastante discutido ${ }^{36,110}$, devido à grande frequiência de resultados falsopositivos. Isto contribuiu para o surgimento de inúmeras técnicas ${ }^{36,45,106}$. Para impedir a entrada de microrganismos contaminantes nas amostras, WINKLER; MITCHELL; HEALEY ${ }^{110}$ empregaram lesões firmemente aderidas aos ápices, cuja continuidade da superfície externa da lesão com o ligamento periodontal mantinhase intacta.

O método de coloração de Brown e Brenn, introduzido à técnica microscópica em 1931, surgiu da necessidade de se pesquisar bactérias Grampositivas e Gram-negativas em cortes de tecidos embebidos em parafina ${ }^{9,14}$. A maior dificuldade encontrada na técnica está na evidenciação das bactérias Gramnegativas, que em muitas situações não se coram ou o fazem fracamente ${ }^{100}$.

O efeito cumulativo sobre os tecidos, pelos agentes químicos empregados na desinfecção, fixação, desmineralização e inclusão em parafina, faz com que partes das bactérias sejam eliminadas ou percam a capacidade tintorial pela técnica de Brown e Brenn ${ }^{108}$. Esta limitação técnica pode levar a falsas interpretações dos cortes em tecidos, podendo influenciar no resultado final de um trabalho.

Os resultados obtidos pelo emprego do EDTA, associado aos efeitos das radiações microondas na desmineralização dos espécimes, foram considerados satisfatórios, pois preservaram o arcabouço estrutural dos tecidos, permitindo a coloração de bactérias nas estruturas mineralizadas e nos tecidos moles. 
Este método tem oferecido os melhores resultados ${ }^{86}$, porém não é o ideal, pois de acordo com os trabalhos de WIJNBERGEN; VAN MULLEM ${ }^{108}$, substâncias químicas utilizadas na desmineralização de tecidos, testadas e empregadas em seu experimento, contribuíram para a perda da afinidade tintorial de bactérias Gram-positivas. As alterações mais significantes foram observadas com $o$ ácido fórmico a 5\%, empregado por uma semana. A cada 15 bactérias, somente uma corou de azul, porém, com EDTA a redução foi menor, corou uma a cada três. Portanto, em áreas com limitado número de bactérias, o risco para resultados falso-negativos torna-se bastante significativo ${ }^{108}$. Isto nos leva a concluir que parte das bactérias contidas nos espécimes por nós estudados, possivelmente não tenha sido detectada (Figura 38).

Alguns trabalhos publicados com a técnica de Brown e Brenn ${ }^{1,59}$ utilizaram o ácido fórmico como substância desmineralizadora, provavelmente pelo curto tempo requerido para tal procedimento. Baseado nos resultados obtidos por WIJNBERGEN; VAN MULLEM ${ }^{108}$, pode-se concluir que este método de desmineralização leva a uma maior perda da afinidade tintorial das bactérias, quando se emprega a técnica de coloração de Gram.

Os resultados quanto à redução no tempo de desmineralização dos espécimes foram evidentes. Enquanto alguns autores relacionam a redução do tempo às radiações microondas, VONGSAVAN et al. ${ }^{105}$ acreditam que o calor gerado pelo forno de microondas seja o principal responsável e não as radiações. Devido à escassez de estudos sobre o assunto, sugerem-se novas pesquisas. 

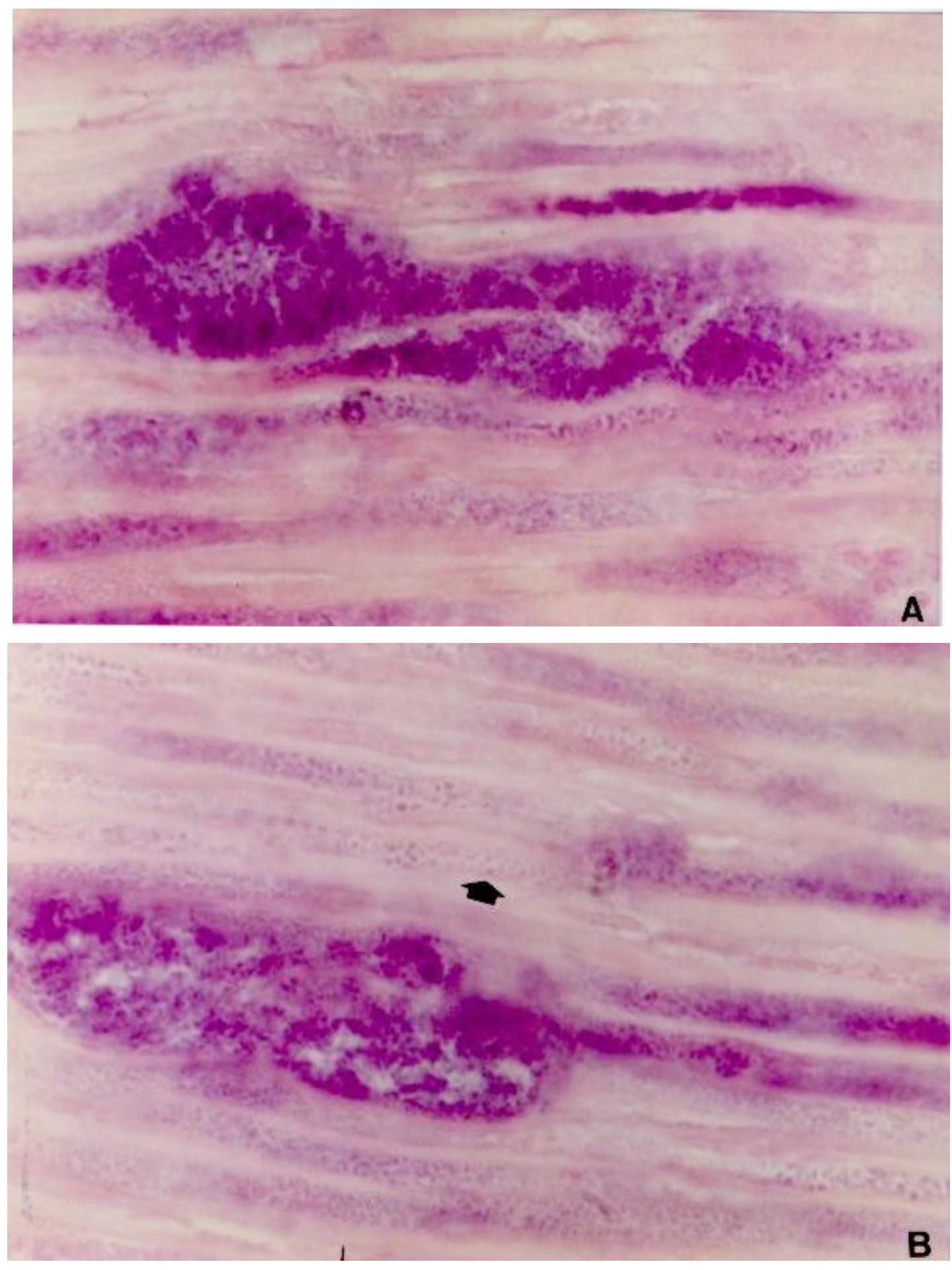

FIGURA 38 - Bactérias e colônias intratubulares. Nota-se a diferença entre a distinção morfológica da coloração H.E. e Brown e Brenn. 

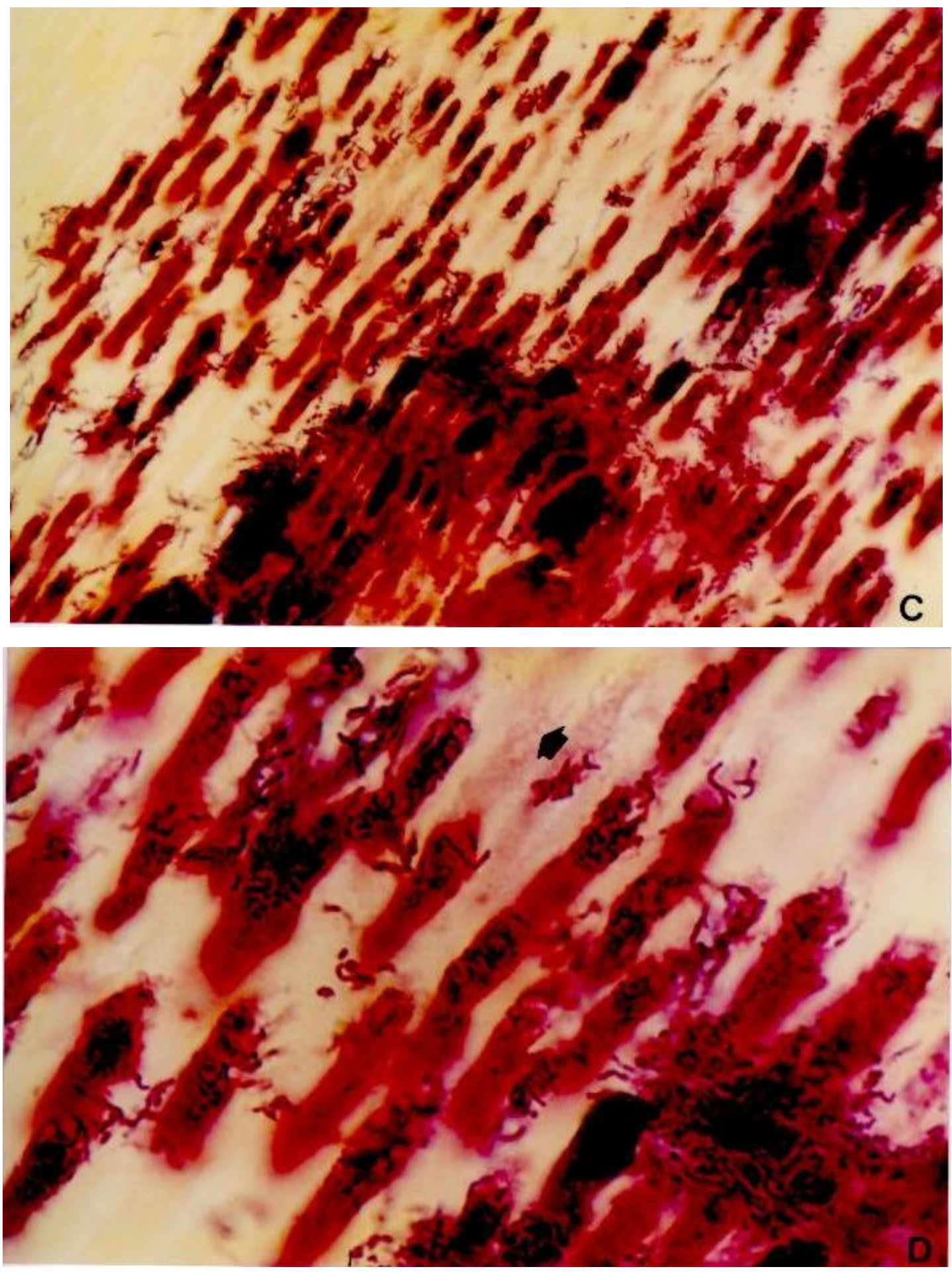

Também distinguem-se sinais de colônias bacterianas intratubulares não evidenciadas significantemente nas duas colorações (setas). (Aumento original: A e $\mathrm{B}=400 \mathrm{X}$, H.E.; $\mathrm{C}=160 \mathrm{X}, \mathrm{D}=400 \mathrm{X}$, Brown e Brenn) 


\section{1 - Nomenclatura: placa dentobacteriana apical ou biofilme}

As bactérias em ambientes aquáticos naturais têm uma marcada tendência a interagir com superfícies. O início do processo de adesão é conseguido às custas de açúcares extracelulares. Divisões celulares sucessivas produzem células filhas unidas entre si, iniciando-se assim o desenvolvimento de microcolônias aderentes. A eventual produção de um contínuo biofilme sobre a superfície colonizada se dá em função da divisão celular no interior das microcolônias e novo recrutamento de células do meio ambiente, formando estruturas de 50 a $100 \mu \mathrm{m}$ de diâmetros, protegidas por um escudo de polissacarídeos, dificultando em muito a ação de antibióticos, substâncias químicas e do sistema imune ${ }^{22,79}$. Os biofilmes têm sido estudados exaustivamente, não só na microbiologia, mas em vários ramos da ciência, onde se procuram alternativas, desde novos antibióticos a vibrações por correntes elétricas ${ }^{22,79}$.

Eventuais biofilmes provocam desde corrosões em depósitos de água ao mau funcionamento de "chips" de computadores. As bactérias anaeróbias em biofilmes reduzem enxofre a sulfureto de hidrogênio, e as aeróbias corroem metais por oxidação. As aplicações benéficas dos biofilmes, como em biobarreiras na indústria do óleo, estão sendo continuamente aperfeiçoadas, quer seja maximizando várias atividades bacterianas para preencher orifícios com seus crescimentos, ou degradando contaminantes específicos ${ }^{79}$.

As bactérias que infectam a região periapical por meio do canal radicular, via hematogênica ou retrógrada, quando isoladas, quase sempre são "eliminadas" pelas células inflamatórias ou do sistema imunológico. Todavia, 
quando coagregadas, em colônias, ou aderidas à superfície radicular, formam placas dentobacterianas, biofilme dos mais comuns, dificultanto a ação das células fagocitárias, devido às suas dimensões.

Entre os biofilmes largamente encontrados na natureza e processos industriais, o mais comum corresponde à placa dentobacteriana depositada ou formada na superfície dos tecidos dentários mineralizados coronários expostos ao meio bucal. Na região apical e nas superfícies internas do canal, também têm-se estas placas dentobacterianas, as quais TRONSTAD ${ }^{102}$ denomina de placa dentobacteriana apical. Elas correspondem a um dos vários tipos de biofilmes; chamá-los simplesmente de biofilmes significa perda de especificidade embora não signifique um erro terminológico. Deve-se preferir o termo mais específico e preciso de placa dentobacteriana apical, para não se deixar levar pelo modismo terminológico.

\section{2 - Alterações morfológicas do terço apical radicular}

A análise morfológica da superfície radicular interna no terço apical, na maioria dos espécimes, evidencia irregularidades com depósitos de dentina reacional, onde se observam, freqüentemente, nichos bacterianos em seus defeitos estruturais, denotando a importância da instrumentação do canal associada às soluções irrigadoras com poder bactericida e de baixa tensão superficial, em dentes com necrose pulpar. 
O fenótipo desta dentina reacional está diretamente relacionado à velocidade de sua deposição. Apresenta-se, de um modo geral, com poucos túbulos dentinários, irregularmente distribuídos, com diâmetros e comprimento irregulares, e, às vezes, algumas inclusões celulares ${ }^{21}$. Estas peculiaridades têm duas facetas: dificultam a penetração bacteriana para o interior de seus túbulos; por outro lado, permitem o alojamento de colônias bacterianas em seus defeitos estruturais, quando presentes.

Em alguns espécimes, foram observados nódulos pulpares livres no lume do canal, ou aderidos à dentina (Figuras 3 e 17). As suas presenças no terço apical do canal radicular têm significados clínicos relevantes na Endodontia, podendo se despreender das paredes dentinárias durante o preparo biomecânico, obstruindo o conduto, podendo assim comprometer o tratamento.

$\mathrm{Na}$ amostragem do grupo $\mathrm{B}$, em cinco casos, os canais radiculares em seus terços apicais apresentam-se com formas ovaladas, elípticas ou em forma de $\mathrm{C}$, e no restante dos espécimes, circulares. A presença de formas de canais radiculares que fogem do padrão circular, no terço apical da raiz, oferece dificuldades para o endodontista, relacionadas ao desbridamento do canal, instrumentação, adaptação do cone de guta-percha principal e controle de extravasamento do material obturador, podendo assim influenciar negativamente no resultado final do tratamento endodôntico.

Estes achados nem sempre podem ser identificados por exames radiográficos. A adaptação de um cone de guta-percha numa visão radiográfica bidimensional, pode não condizer com o real. Espaços vazios entre a parede do canal e o material obturador permitem o intercâmbio entre bactérias, que porventura 
sobreviveram ao preparo biomecânico e encontram-se alojadas no interior de túbulos dentinários, com tecidos da região periapical, acarretando na reinfecção da área, o que denota a persistência de certas lesões à terapia endodôntica.

A nitidez no limite da união cemento-dentinária, no plano bidimensional, foi observada em somente dois espécimes do grupo A, enquanto KUTLER $^{53}$ observou $74 \%$ em dentes hígidos. A disparidade dos resultados deveuse a áreas de reabsorções, freqüentemente observadas nas paredes do canal cementário e/ou dentinário de dentes portadores de periapicopatias crônicas. Isto retrata a importância das reabsorções na terapia endodôntica. É importante frisar ainda, que este ponto de junção cemento-dentina, observado pela microscopia óptica, não retrata a realidade em toda a área de união; pois esta junção, provavelmente se dá em diferentes planos, tal como ocorre também na junção amelocementária, demonstrado por NEUVALD; CONSOLARO ${ }^{70}$.

Considerando as limitações inerentes à microscopia óptica, é importante mencionar, que em cinco espécimes do grupo $\mathrm{A}$, os túbulos dentinários, no plano de corte da porção mais apical da dentina radicular, apresentavam-se isentos de bactérias, sugerindo obliteração dos túbulos por depósitos de dentina reacional atubular ou pela projeção do cemento sobre as paredes dentinárias a uma curta distância. Talvez, aí esteja um dos fatores que contribuem para o alto índice de sucesso endodôntico em dentes portadores de necrose pulpar e periapicopatias crônicas. 
Nos resultados apresentados nas Figuras 6 e 20, observa-se o alto índice de reabsorções inflamatórias na superfície apical. Estas reabsorções são vistas freqüentemente em dentes portadores de periapicopatias crônicas. No granuloma apical, junto à desembocadura do forame, observa-se intensa interação de leucócitos polimorfonucleares com bactérias oriundas do canal radicular. Isto pode levar cementoblastos à morte ou a migrarem da região, propiciando a instalação do processo reabsortivo ${ }^{58}$.

A abertura correspondente ao forame apical deu-se no vértice apic al da raiz, na maioria das amostras, e somente em seis situações ocupou uma posição lateral. Em contrapartida, trabalhos realizados em dentes hígidos evidenciaram o ponto de emergência foraminal numa posição lateral em $68 \%$ a $80 \%$ dos $\operatorname{casos}^{53}$.

Estes resultados nos permitem concluir que alterações morfológicas significativas modificam a posição espacial do forame apical, acarretando em implicações clínicas diversas, tais como: dificuldades na modelagem do canal, na adaptação do cone principal, controle no extravasamento do material obturador, e conseqüentemente podendo permitir a comunicação de bactérias alojadas nos túbulos dentinários com a região periapical.

Nossos resultados são comparáveis aos de GUTIERREZ; $\mathrm{AGUAYO}^{37}$, que analisando ápices radiculares pela microscópica eletrônica de varredura encontrou 1 a 16 foraminas por espécime. Ressalta-se aqui a importância dessas foraminas na clinica endodôntica, pois nas infecções pulpares, os canais acessórios constituintes do delta apical também podem estar comprometidos. 
Como estes são inacessíveis aos instrumentos endodônticos, justifica-se o uso de soluções químicas com propriedades bactericidas, baixa tensão superficial e solventes de tecidos necróticos, como também curativos de demora a base de antimicrobianos, porém biocompatíveis, devido às proximidades com os tecidos vivos da região periapical.

\section{3 - Microbiota dos canais radiculares}

Com o aprimoramento das técnicas de culturas em anaerobiose, tem-se observado uma maior presença de anaeróbios estritos nas infecções pulpares, caracterizando a microbiota dos canais radiculares, como predominantemente anaeróbia. Os Streptococcus, que até então eram considerados os principais agentes etiológicos das infecções pulpares e periapicais, passaram a ocupar um papel secundário.

Os microrganismos mais freqüentemente isolados das polpas infectadas são provenientes da microbiota bucal, muito variável, envolvendo, em média 5 a 6 espécies $^{72}$.

\section{4 - Distribuição das bactérias no lume do canal}

As Figuras 3 e 17, demonstram o conteúdo pulpar no terço apical do canal radicular e a distribuição dos cocos, bacilos e espirilos no lume do canal principal e nos acessórios. As bactérias foram observadas em todos os espécimes analisados, concluindo-se ser alta a sua frequiência em canais com polpas necrosadas e expostas ao meio bucal. 
Apresentam-se freqüentemente em grandes quantidades ora livres, ora formando colônias, permeadas ou não por restos necróticos, livres no lume do canal ou aderidas às suas paredes, às vezes penetrando nos túbulos.

A polpa necrótica infectada pode servir de depósito para bactérias altamente virulentas. A sua remoção inspira cuidados, pois a extrusão de material infectado para a região periapical pode gerar quadros clínicos bastante significativos. O valor médio encontrado por ZAVISTOSKI et al. ${ }^{113}$, por grama de tecido necrótico, gira em torno de de $10^{7.7}$ unidades formadoras de colônias.

Considerando a quantidade de bactérias no lume do canal e os produtos tóxicos originados, diversos autores têm se procupado em analisar as soluções químicas empregadas rotineiramente nos tratamentos endodônticos. BYSTRÖM; SUNDQVIST ${ }^{18}$, em 1983, obtiveram testes bacteriológicos negativos em 12 de 15 amostras tratadas com hipoclorito de sódio a $0,5 \%$.

Em alguns espécimes, onde os canais acessórios foram observados, estes apresentavam-se infectados por cocos e bacilos Gram-positivos, livres ou em colônias, distribuídos aleatoriamente no lume do canal ou aderido às suas paredes.

Os nossos achados são comparáveis aos de $\mathrm{NAIR}^{68}$, que em microscopia óptica e eletrônica detectou bacilos Gram-positivos no interior de canais acessórios. A maioria das lesões persistentes ao tratamento endodôntico provavelmente esteja relacionada a fatores que permitam a viabilidade de microrganismos residuais no sistema de canal radicular, pós terapia endodôntica ${ }^{69}$. 
Em dois espécimes do grupo A, notamos a presença de um "plug bacteriano" nas proximidades da abertura correspondente ao forame apical, e relacionado com áreas de reabsorções cementárias e dentinárias. Nos procedimentos operatórios do preparo biomecânico de canais radiculares com polpas necróticas, a escolha da técnica e a habilidade do profissional são fatores importantes para o sucesso terapêutico.

O grupo de professores de Endodontia da Universidade de Oregon preconizou e implementou uma técnica, por eles chamada de "crown-down pressureless technique" que é efetuada de modo a não bombear restos necróticos, como ocorre nas técnicas clássicas convencionais, sem pressão dos instrumentos em direção coroa-ápice ${ }^{61}$. Esta técnica é hoje considerada uma das que menos produzem extrusão de restos necróticos através do forame apical, devido à sua própria natureza e princípios ${ }^{24}$. O "plug bacteriano", provavelmente, não seria levado parcialmente ou totalmente à região periapical.

Independentemente da causa, os agentes infectantes da polpa são geralmente originários da microbiota bucal. Porém, a microbiota dos canais radiculares é bastante dinâmica ${ }^{72}$, devido às variações ambientais e à disponibilidade de nutrientes do meio ${ }^{98}$. Estudos realizados em culturas evidenciaram que polpas necróticas em dentes com coroas intactas, relacionados a traumas, nem sempre encontram-se infectadas ${ }^{15,60,111}$.

Em especial, no terço apical há algumas peculiaridades. FABRICIUS et al. ${ }^{26}$ evidenciaram $50 \%$ de anaeróbios em polpas infectadas 
experimentalmente após 90 dias, e 65\% a 98\% aos 1060 dias. Notaram grande superioridade de anaeróbios estritos no terço apical, predominantemente bacilos Gram-positivos e Gram-negativos, creditando a eles o importante papel na etiologia e manutenção das lesões periapicais.

A origem das bactérias na polpa e, por extensão, no canal radicular pode ser hematogênica. TZIAFAS ${ }^{104}$ demonstrou experimentalmente o fenômeno da anacorese, infectando polpas previamente inflamadas por meio de suspensão de Streptococcus injetados pela via intravenosa. A instalação dessas bactérias por via anacorética acontece durante bacteriemias transitórias, quando o sistema fagocitário mononuclear não consegue interceptá-las antes de atingirem áreas previamente inflamadas. Isto também pode explicar os resultados negativos relatados na literatura, em algumas culturas de polpas necrosadas relacionadas a traumas, quando não houve qualquer comunicação com o meio bucal.

\section{5 - Distribuição das bactérias na dentina}

O microambiente dos túbulos dentinários parece favorecer $\mathrm{o}$ crescimento de algumas espécies bacterianas, sem restrições à natureza da causa do processo infeccioso $^{72}$. Este constitui um importante reservatório bacteriano dos canais infectados, sendo possível a reinfecção destes, durante ou após o tratamento endodôntico ${ }^{72}$.

Os resultados referentes aos grupos $\mathrm{A}$ e $\mathrm{B}$, quanto à distribuição bacteriana nos túbulos dentinários, evidenciaram presença bacteriana na maioria dos espécimes. Pela coloração de Brown e Brenn pôde-se evidenciar cocos e bacilos, Gram-positivos e Gram-negativos. Os cocos e bacilos Gram-negativos 
foram os morfotipos bacterianos predominantes observados. O espectro de espécies tintorialmente viáveis nesta técnica, em material submetido à desmineralização, não foi ainda determinados. Muitas espécies podem estar presentes, mas não serem evidenciadas.

A densidade intratubular foi considerada de leve a moderada, e os túbulos mantiveram-se preservados (Figuras 4 e 18). O inverso pôde ser observado na dentina coronária; com alterações tubulares caracterizadas por varicosidades, comuns na dentina cariada ${ }^{21}$ (Figura 38). Esses resultados estão de acordo com o trabalho de AKPATA; BLECHMAN ${ }^{1}$, que utilizaram metodologia semelhante, porém avaliando a penetração bacteriana nos três terços da raiz. A densidade bacteriana intratubular foi significantemente menor no terço apical.

O predomínio dos morfotipos bacterianos Gram-negativos no interior dos túbulos dentinários do terço apical provavelmente esteja relacionado aos fatores ambientais e às inter-relações entre as espécies, baseadas em demandas e relações nutricionais. Dessa maneira, BAUMGARTNER; FALKLER ${ }^{6}$, estudando a microbiota dos 5mm apicais, isolaram $68 \%$ de anaeróbios estritos.

Neste trabalho, com respeito à penetração bacteriana nos túbulos dentinários do terço apical, o que mais nos chamou a atenção foram os cinco espécimes nos quais as bactérias atingiram as proximidades da junção cementodentina. Provavelmente, muitos casos de canais radiculares prontos para serem obturados, quando realizados testes de cultura bacteriana, não haverá positividade, embora, na região possam existir bactérias nos túbulos dentinários ${ }^{17}$. Portanto, o resultado positivo ou negativo de um teste bacterioló gico não indica, 
necessariamente, a presença ou a ausência de bactérias no sistema de canal radicular, embora reconheça-se o seu valor, seu uso na prática endodôntica restringe-se a determinadas situações.

As inclusões bacterianas intratubulares localizadas mais próximas à junção dentina-cemento podem resistir ao preparo biomecânico e à ação da medicação intracanal. Seladas na dentina, tornam-se quiescentes nos canalículos, podendo ser reavivadas por fluidos provenientes da região periapical, devido ao selamento inadequado da obturação do canal, reiniciando o processo infeccioso. Essas bactérias podem ainda chegar à superfície apical e ao periodonto, se houver reabsorções extensas com exposição dentinária, podendo perpetuar a lesão periapical crônica, pretensamente tratada endodonticamente.

ØRSTAVIT; KEREKES; MOLVEN ${ }^{74}$ realizaram alargamento extensivo do terço apical do canal radicular em dentes portadores de periodontites apicais de origem bacteriana, aplicarando curativo de hidróxido de cálcio por sete dias. Das 23 amostras infectadas, 22 apresentaram-se negativas para crescimento bacteriano no final do experimento. O diâmetro final do alargamento utilizado pelo autor correspondeu aos instrumentos 35 a 80 (referências correspondentes aos diâmetros das extremidades ativas dos instrumentos, expressas em centésimos de milímetros). O que só foi possível por tratar-se de dentes unirradiculados com canais amplos e retos. Por entender que o índice de dentes afetados endodonticamente nem sempre comporta um alargamento extensivo, estes resultados não devem ser extrapolados para a clínica. 
$\mathrm{LOVE}^{59}$, em 1996, encontrou uma extensão de penetração bacteriana nos túbulos dentinários do terço apical, de aproximadamente $60 \mu \mathrm{m}$. A extensão de penetração bacteriana nos túbulos dentinários do terço apical radicular é relativamente menor, em comparação aos terços médio e cervical da raiz. ${ }^{59,92}$. Isto favorece as técnicas endodônticas que preconizam uma preparação apical mínima, com alargamento coronalmente mais acentuado, removendo-se assim a grande quantidade de dentina infectada nos terços cervical e médio ${ }^{59}$.

Nossos resultados não são comparáveis aos de $\operatorname{LOVE}^{59}$, pois este autor utilizou como modelo experimental dentes hígidos recém-extraídos, inoculados com Streptococcus gordonii por somente sete dias. A situação dos dentes analisados neste trabalho são correspondentes a portadores de lesões periapicais crônicas, onde a necrose pulpar e sua contaminação se deram há muitas semanas, meses ou anos. A complexidade da microbiota e das condições locais levaram à ampla contaminação estrutural da dentina.

As células formadoras da dentina são muitas vezes incluídas na substância intercelular produzidas rapidamente, podendo degenerar e vagar os espaços que ocupavam anteriormente ${ }^{4}$, especialmente quando sob agressões como nas pulpites. A presença desses espaços observados no plano de corte de alguns espécimes, revelou que, freqüentemente, estavam preenchidos por depósitos de colônias bacterianas, com predomínio do tipo Gram-negativo. Provavelmente esta camada de dentina reacional, altamente infectada, seja excisionada durante a modelagem do canal, se não toda, grande parte dela. Nestas circunstâncias, a remoção do "smear layer" é extremamente necessária. 
A profundidade de penetração bacteriana nos túbulos dentinários está na dependência de uma série de fatores, tais como: localização dos túbulos, morfologia, terço radicular envolvido, tipo e morfologia bacteriana, tempo de inoculação, cavidades fechadas ou abertas e idade cronológica do dente. Com o preparo biomecânico consegue-se remover as bactérias alojadas no interior dos túbulos, mas não necessariamente todas. Por isto julgamos ser de grande valia o uso de curativo anti-séptico intracanal. O sucesso do tratamento endodôntico de dentes portadores de necrose pulpar depende de uma série de fatores. Entre eles, o mais importante é a redução ou eliminação das bactérias da cavidade pulpar e a remoção dos substratos dos quais depende ${ }^{31,94}$.

\section{6 - Distribuição das bactérias no canal cementário}

A presença detectada e predominante de cocos e bacilos Gramnegativos nas lacunas de reabsorção das paredes do canal cementário tem grande significado clínico. Considerando os aspectos morfológicos das paredes do canal, determinadas áreas não são atingidas pelos instrumentos endodônticos. As bactérias remanescentes podem manter o processo inflamatório, mesmo após o tratamento endodôntico. Esses achados corroboram com LIN et al. ${ }^{57}$, ao analisarem 150 casos de insucessos endodônticos quando evidenciaram quantidades variáveis de debris infectados no interior do canal, nas proximidades da abertura correspondente ao forame apical, associados à inflamação periapical severa e reabsorções cementárias e/ou dentinárias. Sugere-se que a maioria dos fracassos endodônticos esteja relacionada à infecção bacteriana ${ }^{38,42,51,69,95,103,107}$. 
Áreas de reabsorções envolvendo todas as paredes do canal cementário e partes do dentinário, deixando a dentina da superfície apical parcialmente desnuda, traduzem-se em grandes obstáculos para o tratamento endodôntico, pela comunicação direta de túbulos dentinários contaminados com a região periapical e pela dificuldade na remoção das bactérias das irregularidades de suas paredes, durante o preparo biomecânico (Figura 39).
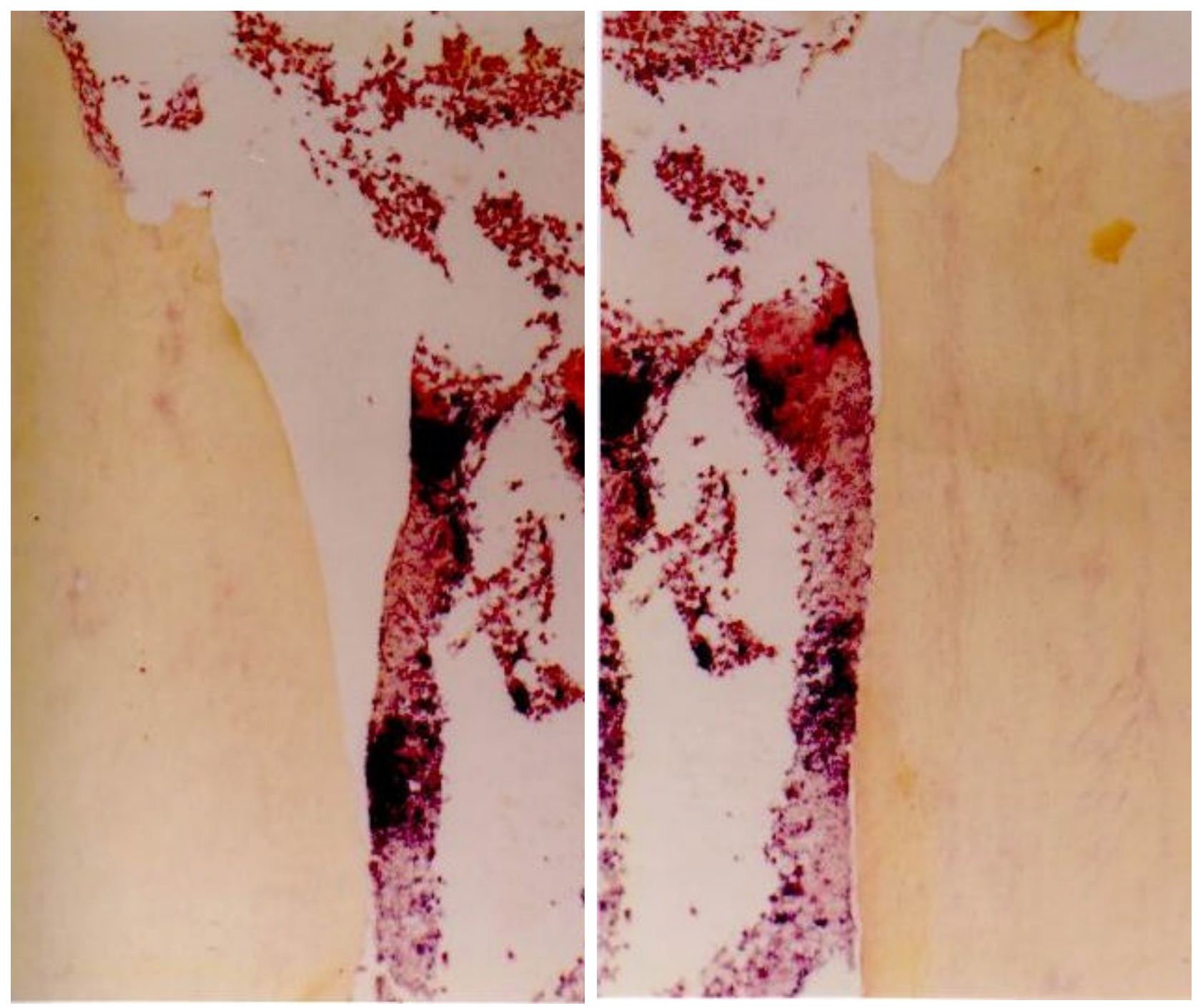

FIGURA 39 - Colônias bacterianas Gram-positivas e Gram-negativas no lume do canal de um dente com necrose pulpar e granuloma apical associada à presença de extensa reabsorção radicular, com perda da regularidade e dos limites anatômicos do terço apical. (Aumento original: A e B = 40X; Brown e Brenn) 


\section{7 - Distribuição das bactérias na superfície apical}

As reabsorções inflamatórias, associadas às periapicopatias crônicas, fizeram-se presentes na grande maioria dos espécimes (Figuras 6 e 20). Resultados similares foram encontrados por outros autores ${ }^{3,57,95,102}$. Em dez espécimes a dentina também foi envolvida no processo reabsortivo, situação preocupante, pois a desnudação da dentina no terço apical expõe cerca de 8.000 túbulos por milímetro quadrado ${ }^{19}$.

O exame em microscopia de luz evidenciou bactérias intimamente relacionadas à superfície apical, em 21 espécimes, pertencentes aos grupos A e B (Figuras 6 e 20). Os dados revelaram que estas se apresentavam ora isoladas, ora em placas, identificadas, pela coloração de Brown e Brenn como cocos e bacilos Gram-positivos e Gram-negativos, com ligeiro predomínio das formas cocares. Elas se apresentavam localizadas nas proximidades da abertura correspondente ao forame apical, distribuídas aleatoriamente entre as superfícies regulares e irregulares do ápice radicular, e intratubularmente nas áreas de dentina desnuda. Sugere-se que estas bactérias originam-se do canal radicular, sem no entanto descartar-se a via hematogênica. Descarta-se a penetração bacteriana via bolsa periodontal, pois as lesões apresentavam-se intactas clínica e microscopicamente. Todos os cortes microscópicos foram checados, e em nenhum observaram-se alterações na periferia da lesão.

Nossos achados são comparáveis aos de TRONSTAD; BARNETT; CERCONE ${ }^{102}$ que verificaram bactérias na superfície apical de dez dentes portadores de lesões periapicais crônicas, persistentes após o tratamento 
endodôntico. Apresentavam-se organizadas em colônias, em áreas irregulares da superfície apical radicular, entre feixes de fibras colágenas e células inflamatórias. TRONSTAD; KRESHTOOL; BARNETT ${ }^{103}$ confirmaram a presença de placas dentobacterianas, firmemente aderidas à superfície apical radicular.

A formação dessas placas bacterianas pode estar fundamentada nos mesmos processos de formação dos biofilmes bacterianos, que têm sido largamente discutidos no meio científico ${ }^{79}$.

\section{8 - Distribuição das bactérias nos granulomas apicais}

As bactérias podem chegar à lesão periapical pelos seguintes caminhos: canal radicular infectado, vasos linfáticos do periodonto, circulação sistêmica, extensões apicais de bolsas periodontais e lesões periapicais contíguas $^{110}$.

Ao contrário de numerosos estudos sobre a microbiota dos canais radiculares, informações sobre a microbiota das lesões periapicais crônicas precedidas por infecção pulpar, são escassas e controvertidas ${ }^{101}$.

O significante papel das bactérias na indução das doenças periapicais foi confirmado por MÖLLER et al. ${ }^{65}$ demonstrando, em macacos, o desenvolvimento de lesões periapicais em dentes cujas polpas foram infectadas experimentalmente por microrganismos da microbiota bucal. No outro grupo, onde as polpas foram necrosadas assepticamente, apresentaram-se negativas aos testes bacteriológicos após seis meses. 
Os lipopolissacarídeos, componentes da parede celular das bactérias anaeróbias, representam o fator determinante de sua patogenicidade. São moléculas de temperatura estável, compostas de polissacarídeos e fosfolipídios. Desenvolvem importante papel na interação de bactérias Gram-negativas com as células do hospedeiro, exercendo um alto efeito biológico, pois são capazes de amplificar as respostas inflamatórias e imunopatológicas. São os principais responsáveis pelo desenvolvimento de lesões periapicais.

Neste trabalho, as bactérias foram encontradas em 26 amostras de granulomas aderidos aos ápices, de um total de 28 espécimes passíveis de análise. Apresentavam-se isoladamente ou organizadas em colônias, identificadas pela técnica de coloração de Brown e Brenn como cocos e bacilos Gram-positivos e bacilos Gram-negativos, predominantemente. As colônias apresentam-se ora aderidas à superfície apical, ora dispersas no tecido granulomatoso. As formas livres foram identificadas nos espaços extracelulares, como também no interior de células vacuoladas, compatíveis com macrófagos (Figuras 7 e 21).

Notam-se dispersões uniformes de bactérias no interior do granuloma apical, intimamente relacionadas às células inflamatórias, e freqüentemente engolfadas por elas. Estes achados nos permitem concluir com segurança que as bactérias podem estar presentes nas lesões periapicais crônicas. Estes resultados corroboram com WINKLER; MITCHELL; HEALEY ${ }^{110}$ ao utilizarem 15 dentes extraídos com lesões aderidas aos seus ápices, analisando-os pelas técnicas de coloração em H.E. e Brown e Brenn. Estes autores observaram altas concentrações de bactérias no interior dos canais, e nas lesões, compatíveis com granulomas apicais, encontrando bactérias distribuídas uniformemente em 
concentrações de leve a moderada, com predomínio de cocos e bacilos Grampositivos.

Os achados revelados neste trabalho são bem diferentes dos encontrados por LANGELAND; BLOCK; GROSSMAN ${ }^{54}$, onde a presença de microrganismos em apenas 1 de 35 biópsias coletadas de cirurgias parendodônticas, foi detectada. Essas apresentavam-se intimamente relacionadas aos polimorfonucleares e nas proximidades da abertura correspondente ao forame apical.

Ao comparar nossos resultados com os de outros autores $54,106,110$ que empregaram a mesma técnica de coloração, observa-se uma diferença quantitativa, em relação ao número de espécimes envolvidos, como também o número de invasores, pois foram mencionadas as formas livres, e em concentrações de leves a moderada.

A presença de bactérias na região apical e periapical também foi estudada por TRONSTAD, BARNETT; CERCONE ${ }^{102}$, em 1990, empregando microscopia eletrônica de varredura. Os autores detectaram bactérias ora isoladas, ora em colônias na superfície radicular de dez ápices removidos cirurgicamente. Apresentavam-se nas proximidades da superfície radicular ou firmemente aderidos a ela, em forma de placas. Estes resultados são compatíveis com os deste trabalho, embora tendo sido realizado em microscopia eletrônica de varredura.

A presença de bactérias nas lesões periapicais crônicas tem sido observada por vários autores. Porém, na maioria das vezes, são identificadas 
apenas formas isoladas, próximas da abertura correspondente ao forame apical. Talvez a pequena quantidade identificada se deva às limitações técnicas. BYSTRÖN et al. ${ }^{17}$ verificaram por meio de exames imunocitoquímicos Actinomyces israelii, A. naeslundii e Arachnia propiônica em amostras de lesões persistentes pós-tratamento endodôntico. Sugere-se que as bactérias possam sobreviver na região periapical. Outros autores, empregando a mesma metodologia, obtiveram resultados semelhantes ${ }^{41,68,69}$.

A presença maciça de bactérias na região periapical, como observada em alguns espécimes do trabalho, sugere que estas estejam relacionadas aos aspectos físicos da cavidade pulpar, e não às falhas do sistema imunológico e das células inflamatórias do hospedeiro.

O tratamento endodôntico não cirúrgico, em dentes portadores de necrose pulpar e periapicopatias crônicas, tem revelado uma alta taxa de sucesso, girando em torno de $84 \%$ a $93 \%{ }^{17,68,91}$, graças aos recursos da terapia endodôntica, visando a eliminação das bactérias do sistema de canal radicular, por intermédio de um conjunto de procedimentos como: preparo biomecânico associado a substâncias químicas irrigadoras com poder antibacteriano, emprego de curativos antibacterianos intracanal e selamento adequado do sistema de canal $\operatorname{radicular}^{17,25,41,69}$.

As alterações patológicas da região periapical, originadas da necrose pulpar infecciosa, são provavelmente o resultado das reações inflamatórias inespecíficas e de respostas imunológicas específicas. As toxinas bacterianas e/ou as próprias bactérias difundem-se pelo forame apical, desencadeando uma resposta 
inflamatória aguda, e algumas horas após, instalam-se as reações imunopatológicas. Como a fonte imunogênica do canal radicular é contínua, as reações patológicas levam à destruição tecidual da área agredida, tanto mais acentuada quanto maior for a taxa de bactérias anaeróbias na microbiota do canal radicular ${ }^{101}$.

O hipoclorito de sódio tem sido largamente empregado como solução irrigadora auxiliar na instrumentação dos canais radiculares. BYSTRÖM et al. ${ }^{17}$ obtiveram $88 \%$ de êxito, após um período de 2 a 5 anos de proservação, de 79 dentes com infecção pulpar e lesões periapicais, cujos canais foram preparados biomecanicamente com o auxílio da solução de hipoclorito de sódio, recebendo curativos de hidróxido de cálcio e sendo obturados.

Dentre os antimicrobianos empregados como curativo intracanal destaca-se o hidróxido de cálcio, pelo efeito destrutivo sobre as células bacterianas e inativação de seus produtos tóxicos, como também pela biocompatibilidade com os tecidos da região periapical ${ }^{25,31,87}$. Além disso, o hidróxido de cálcio pode mostrar efeito antibacteriano, indiretamente, em especial sobre bactérias alojadas nos túbulos dentinários, canais acessórios, cementoplastos, anfractuosidades nas paredes dentinárias e/ou cementárias, pela adsorção do dióxido de carbono, necessário para a sobrevivência de alguns anaeróbios ${ }^{52}$. A remoção do "smear layer" das paredes do canal radicular após o preparo biomecânico, permite melhor difusibilidade dos íons hidroxila para o sistema de canal e túbulos dentinários ${ }^{39,87}$, como também permite melhor embricamento do material obturador com as paredes do canal radicular ${ }^{8}$. 
Estudos realizados em microscopia óptica e eletrônica, por NAIR ${ }^{68}$, revelaram $10 \%$ de insucesso em dentes tratados endodonticamente, após um período de proservação compreendido entre 4 a 10 anos. Em 6, de 9 casos, observou-se presença de microrganismos no canal principal, canal lateral e delta apical. Observaram-se também colônias bacterianas em áreas de reabsorções, nas paredes internas do canal radicular em seu terço apical, corroborando com os achados deste estudo. Sugere-se que a maioria das lesões persistentes após o tratamento endodôntico, esteja relacionada à viabilidade de microrganismos residuais no sistema de canal radicular.

A persistência de lesões periapicais após aplicação da terapia endodôntica pode estar relacionada a diversas causas, tais como: bactérias remanescentes em túbulos dentinários expostos à superfície radicular, nas lacunas do cemento celular, nas foraminas apicais e em raspas de dentina e/ou de cemento contaminados, lançados para a região periapical durante o preparo biomecânico. Além disso, bactérias do gênero Actinomyces e Arachnia podem dificultar o reparo, por serem capazes de sobreviver na região periapical ${ }^{17}$.

As implicações clínicas dos achados deste estudo reafirmam a necessidade de uma terapia endodôntica embasada no preparo biomecânico, curativo intracanal e obturação, objetivando a eliminação das bactérias do sistema de canal radicular ou tornando-as inviáveis, visando o reparo da região periapical. 
7 - CONCLUSÕES 


\section{7 - CONCLUSÕES}

A partir dos resultados obtidos, considerando-se as limitações inerentes à metodologia empregada, pôde-se verificar:

1 - uma elevada frequiência de bactérias no lume do canal do terço apical radicular, com predomínio de cocos e bacilos Gram-positivos e Gramnegativos, distribuídos isoladamente ou em colônias, por vezes aderidos à parede do canal;

2 - a presença de bactérias nos túbulos dentinários do terço apical radicular, estendendo-se do terço pulpar circunferencial ao terço superficial circunferencial da dentina, nas formas de cocos e bacilos Gram-positivos e Gramnegativos;

3 - a presença de bactérias Gram-positivas e Gram-negativas na superfície radicular apical externa ora isoladas, ora organizadas em placas firmemente aderidas, com predomínio de cocos e bacilos;

4 - a presença de bactérias Gram-positivas e Gram-negativas nos granulomas apicais, com predomínio de cocos e bacilos, distribuídos em colônias ou isoladamente, nos espaços extracelulares e/ou no interior de células macrofágicas. 
Assim, pôde-se concluir: nos dentes com necrose pulpar e granulomas apicais, as bactérias envolvem todo o sistema de canal radicular, incluindo-se os túbulos dentinários, e freqüentemente os tecidos da região periapical. Mais uma vez, fundamenta-se a necessidade do preparo biomecânico auxiliado por substâncias químicas antibacterianas, emprego de curativos no interior do canal, além do selamento adequado do sistema de canal radicular, em tratamentos endodônticos de dentes com necrose pulpar e lesão periapical crônica. 


\section{REFERÊNCIAS BIBLIOGRÁFICAS}




\section{REFERÊNCIAS BIBLIOGRÁFICAS*}

1- AKPATA, E.S.; BLECHMAN, H. Bacterial invasion of pulpal dentin wall in vitro. J. dent. Res., v.61, n.2, p.435-8, Feb. 1982.

2- ALIN, K.; AGREN, E. The bacterial flora of odontogenic infections and sensitivity to antibiotics. Acta odont. scand., v.12, p.85-98, Nov. 1954.

3- ARTESE, L. et al. Immunoreactivity for interleukin $1 \beta$ and tumor necrosis factor- $\alpha$ and ultrastructural features of monocytes/macrophages in periapical granulomas. J. Endod., v.17,n.10, p.483-7, Oct. 1991.

4- AVERY, J.K. Dentina. In: BHASKAR, S.N. Histologia e embriologia oral de Orban. 8.ed. São Paulo, Artes Médicas, 1978. Cap.4, p.107-42.

5- BARNETT, F.; STEVENS, R.; TRONSTAD, L. Demonstration of Bacteroides intermedius in periapical tissue using indirect immunofluorescence microscopy. Endod. dent. Traumat., v.6, n.4, p.153-6, Aug. 1990.

6- BAUMGARTNER, J.C.; FALKLER, W.A. Bacteria in the apical $5 \mathrm{~mm}$ of infected root canals. J. Endod., v.17, n.8, p.380-3, Aug. 1991.

7- BAUMGARTNER, J.C.; WATKINS, B.J.; BAE, K.S. Identification of bacterial species in root canal infections. J. Endod., v.22, n.4, p.200, Apr. 1996. /Abstract n.49/

8- BEHREND, G.D.; CUTLER, C.W.; GUTMANN, J.L. Smear layer removal and microbial leakage along root canal fillings. J. Endod., v.22, n.4, p.201, Apr. 1996. /Abstract n.52/

9- BIER, O. Microbiologia e imunologia. 2.ed. São Paulo, Ed. Santos, 1985. p.19-28.

* Normas recomendadas para uso no âmbito da Universidade de São Paulo, com base no documento "Referências Bibliográficas: exemplos", emanado do Conselho Superior do Sistema Integrado de Biblioteca da USP, em reunião de 20 de setembro de 1990. 
10- BIRCH, R.H.; MELVILLE, T.H.; NEUBERT, E.W. A comparis on of rootcanal and apical lesion flora. Brit. dent. J., v.116, n.8, p.350-2, Apr. 1964.

11- BOHÓRQUEZ AVILA, S.P. Avaliação da presença e localização de bactérias nos canais radiculares e nas lesões periapicais crônicas pelo método de coloração de Brown e Brenn e pela imunofluorescência indireta para Prevotella intermedia. Bauru, 1994. 128p. Tese (Mestrado) - Faculdade de Odontologia de Bauru, Universidade de São Paulo.

12- BOHÓRQUEZ AVILA, S.P.; ROCHA, R.S.S.; CONSOLARO, A. Avaliação da presença e localização de bactérias nos canais radiculares e nas lesões periapicais crônicas pelo método de coloração de Brown e Brenn. Rev. FOB, v.3, n.1/4, p.25-31, jan./dez. 1995.

13- BOYLE, P.E. Intracellular bacteria in a dental granuloma. J. dent. Res., v.14, n.4, p.297-301, 1934.

14- BROWN, J.H.; BRENN, L. A method for the differential staining of Grampositive and Gram-negative in tissue sections. Bull. Johns Hopk. Hosp., v.48, n.2, p.69-73, 1931.

15- BROWN, L.R.; RUDOLPH, C.E. Isolation and identification of microorganisms from unexposed canals of pul-involved teeth. Oral Surg., v.10, n.10, p.1094-9, Oct. 1957.

16- BURKE, G.W.; KNIGHTON, H.T. The localization of microorganisms in inflamed dental pulps of rats following bacteremia. J. dent. Res., v.39, n.2, p.205-14, Mar./Apr. 1960.

17- BYSTRÖM, A. et al. Healing of periapical lesions of pulpless teeth after endodontic treatment with controlled asepsis. Endod. dent. Traumat., v.3, n.2, p.58-63, Apr. 1987.

18- BYSTRÖM, A.; SUNDQVIST, G. Bacteriologic evaluation of the effect of 0.5 percent sodium hypochlorite in endodontic therapy. Oral Surg., v.55, n.3, p.307-12, Mar. 1983. 
19- CARRIGAN, P.J. et al. A scanning electron microscopic evaluation of human dentinal tubules according to age and location. J. Endod., v.10, n.8, p.35963, Aug. 1984.

20- CHIRNSIDE, I.M. Bacterial invasion of non-vital dentin. J. dent. Res., v.40, n.1, p.134-40, Jan./Feb. 1961.

21- CONSOLARO, A. Cárie dentária-histopatologia e correlações clínicoradigráficas. Bauru, Ed. Consolaro, 1985. p.48.

22- COSterton, J.W. et al. Bacterial biofims in nature disease. Ann. Rev. Microbiol., v.41, p.465-505, 1987.

23- DEBELIAN, G.J.; OLSEN, I.; TRONSTAD, L. Bacteremia in conjunction with endodontic therapy. Endod. dent. Traumat., v.11, n.3, p.142-9, June 1995.

24- DE DEUS, Q.D. Endodontia. 5.ed. Rio de Janeiro, Medsi, 1992. p.334-92.

25- ESBERARD, R.M.; CARNES JÚNIOR, D.L.; DEL RIO, C.E. Changes in pH at the dentin surface in roots obturated with calcium hydroxide pastes. J. Endod., v.22, n.8, p.402-5, Aug. 1996.

26- FABRICIUS, L. et al. Predominant indigenous oral bacteria isolated from infected root canals after varied times of closure. Scand. J. dent. Res., v.90, n.2, p.134-44, Apr. 1982.

27- FARBER, P.A.; SELTZER, S. Endodontic microbiology. I. Etiology. J.Endod., v.14, n.7, p.363-71, July 1988.

28- FERLINI FILHO, J.; GARCIA, R.B. Estudo microscópico da evolução dos processos de reabsorção apical provocada por periopontites apicais crônicas - Bauru, 1997. Tese (Doutorado) - Faculdade de Odontologia de Bauru, Universidade de São Paulo. /Trabalho em andamento - Orientador: Prof. Dr. Roberto Brandão Garcia/

29- FISHER, F.J. The viability of micro-organisms in carious dentine beneath amalgam restorations. Brit. dent. J., v.121, n.1, p.413-6, Nov. 1966. 
30- FUKUSHIMA, H. et al. Localization and identification of root canal bacteria in clinically asymptomatic periapical pathosis. J. Endod., v.16, n.11, p.534-8, Nov. 1990.

31- GEORGOPOULOU, M.; KONKAKIOTIS, E.; NAKOU, M. In vitro evaluation of the effectiveness of calcium hydroxide and paramonochlorophenol on anaerobic bacteria from the root canal. Endod. dent. Traumat., v.9, n.6, p.249-53, Dec. 1993.

32- GIER, R.E.; MITCHELL, D.F. Anachoretic effect of pulpitis. J. dent. Res., v.47, n.4, p.564-70, July/Aug. 1968.

33- GOING, R.E. et al. The viability of microoganisms in carious lesions five years after covering with a fissure sealant. J. Amer. dent. Ass., v.97, n.3, p.455-62, Sept. 1978.

34- GRIFFEE, M.B. et al. Bacteroides melaninogenicus and dental infections: some questions and some answers. Oral Surg., v.54, n.4, p.486-9, Oct. 1982.

35- GRIFFEE, M.B. et al. The relationship of Bacteroides melaninogenicus to symptoms associated with pulpal necrosis. Oral Surg., v.50, n.5, p.45761, Nov. 1980.

36- GROSSMAN, L.I. Bacteriologic status of periapical tissue in 150 cases of infected pulpless teeth. J. dent. Res., v.38, n.1, p.101-4, Jan./Feb. 1959.

37- GUTIERREZ, J.H.; AGUAYO, P. Apical foraminal openings in human teeth. Oral Surg., v.79, n.6, p.769-77, June 1995.

38- HAAPASALO, M. et al. Mixed anaerobic periapical infection with sinus tract. Endod. dent. Traumat., v.3, n.2, p.83-5, Apr. 1987.

39- HAAPASALO, M.; ØRSTAVIK, D. In vitro infection and desinfection of dentinal tubules. J. dent. Res., v.66, n.8, p.1375-9, Aug. 1987.

40- HADEN, R.L. Bacteriology of chronic periapical dental infection. J. Amer. dent. Ass., v.13, p.1370-83, Oct. 1926. 
41- HAPPONEN, R.P. Periapical actinomycosis: A follow-up study of 16 surgically treated cases. Endod. dent. Traumat., v.2, n.5, p.205-9, Oct. 1986.

42- HAPPONEN, R.P. et al. Immunocytochemical demonstration of Actinomyces species and Arachnia propionica in periapical infections. J. oral Path., v.14, n.5, p.405-13, Oct. 1985.

43- HASHIOKA, K. et al. The relationship between clinical syntoms and anaerobic bacteria from infected root canals. J. Endod., v.18, n.11, p.558-61, Nov. 1992.

44- HAUSMAN, E.; WEINFELD, N.; MILLER, W.A. Effects of lipopolysaccharides on bone resorption in tissue culture. Calcif. Tiss. Res., v.9, n.4, p.272-82, 1972.

45- HEDMAN, W.J. An investigation into residual periapical infection after pulp canal therapy. Oral Surg., v.4, p.1173-9, 1951.

46- HORIBA, N. et al. Complement activation by lipopolysaccharides purified from gram-negative bacteria isolated from infected root canals. Oral Surg., v.74, n.5, p.648-51, Nov. 1992.

47- IWU, C. et al. The microbiology of periapical granulomas. Oral Surg., v.69, n.4, p.502-5, Apr. 1990.

48- KAKEHASHI, S.; STANLEY, H.R.; FITZGERALD, R.J. The effects of surgical exposures of dental pulps in germ-free and conventional laboratory rats. Oral Surg., v.20, n.3, p.340-9, Sept. 1965.

49- KELLER, R.; GUSTAFSON, J.E.; KEIST, R. The macrophage response to bacteria: modulation of macrophage functional activity by peptidoglycan from Moraxella (Brahhmella) catarrhalis. Clin. Exp. Immunol., v.89, p.384-9, 1992.

50- KEREKES, K.; OLSEN, I. Similarities in the microfloras of the canals and deep periodontal pockets. Endod. dent. Traumat., v.6, n.1, p.1-5, Feb. 1990. 
51- KIRYU, T. et al. Bacteria invading periapical cementum. J. Endod., v.20, n.4, p.169-72, Apr. 1994.

52- KONTAKIOTIS, E.; NAKOU, M.; GEORGOPOULOU, M. In vitro study of the indirect action of calcium hydroxide on the anaerobic flora of the root canal. Int. Endod. J., v.28, n.6, p.285-9, Nov. 1995.

53- KUTLER, Y. Microscopic investigation of root apexes. J. Amer. dent. Ass., v.50, p.544, 1955.

54- LANGELAND, K; BLOCK, R.M.; GROSSMAN, L.I. A histopathologic and histobacteriologic study of 35 periapical endodontic surgical specimens. J. Endod., v.3, n.1, p.8-23, Jan. 1977.

55- LEUNG, R.L.; LOESCHE, W.J.; CHARBENEAU, G.T. Effect of dycal on bacteria in deep carious lesions. J. Amer. dent. Ass., v.100, p.193-7, Feb. 1980 .

56- LEV, M.; KEUDELL, K.C.; MILFORD, A.F. Succinate as a growth factor for Bacteroides melaninogenicus. J. Bact., v.108, n.1, p.175-8, 1971.

57- LIN, L.M. et al. Clinical, radiographic, and histologic study of endodontic treatment failures. Oral Surg., v.71, n.5, p.603-611, May 1991.

58- LINDSKOG, S.; BLOMLÖF, L.; HAMMARSTRÖM, L. Cellular colonization of denuded root surfaces in vivo: cell morphology in dentin resorption and cementum repair. J. Clin. Periodont., v.14, n.7, p.390-5, Aug. 1987.

59- LOVE, R.M. Regional variation in root dentinal tubule infection by Streptococcus gordonii. J. Endod., v.22, n.6, p.290-293, June 1996.

60- MACDONALD, J.B.; HARE, G.C.; WOOD, A.W.S. The bacteriologic status of the pulp chambers in intact teeth found to nonvital following trauma. Oral Surg., v.10, n.3, p.318-22, Mar. 1957.

61- MARSHALL, F.J.; PAPPIN, J.B. A Crown-Down pressureless preparation root canal enlargement technique. Tecchnique manual. Oregon Health Sciences University, Portland, 1980 apud DE DEUS, Q. D. ${ }^{24}$, p.334-92. 
62- MEIKLE, M.C.; GOWEN, M.; REYNOLDS, J.J. Effect of streptoccal cell wall components on bone cell metabolism in vitro. Calcif. Tiss. Int., v.34, p.359-64, 1982.

63- MELVILLE, T.H.; BIRCH, R.H. Root canal and periapical floras of infected teeth. Oral Surg., v.23, n.1, p.93-8, Jan. 1967.

64- MILLER, W.D. An introduction to the study of the bacterio-pathology of the dental pulp. Dent. Cosmos, v.36, n.7, p.505-28, July 1894.

65- MÖLLER, A.R. et al. Influence on periapical tissues of indigenous oral bacteria and necrotic pulp tissue in monkeys. Scand. J. dent. Res., v.89, p.475-84, Dec. 1981.

66- MORRISON, D.C.; RYAN, J.L. Endotoxins and disease mechanisms. Ann. Rev. Med., v.38, p.417-32, 1987.

67- NAGAOKA, S. et al. Bacterial invasion into dentinal tubules of human vital and nonvital teeth. J. Endod., v.21, n.2, p.70-3, Feb. 1995.

68- NAIR, P.N.R. Light and electron microscopic studies of root canal flora and periapical lesions. J. Endod., v.13, n.1, p.29-39, Jan. 1987.

69- NAIR, P.N.R. et al. Intraradicular bacteria and fungi in root-filled, asymptomatic human teeth with therapy-resistant periapical lesions: A longterm light and electron microscopic follow-up study. J. Endod., v.16, n.12, p.580-8, Dec. 1990.

70- NEUVALD, L.R.; CONSOLARO, A. Estudo morfológico da junção amelocementária sob estereomicroscópio, microscopia óptica e microscopia eletrônica de varredura. Bauru, 1997. Dissertação (Mestrado) - Faculdade de Odontologia de Bauru, Universidade de São Paulo. /Trabalho em andamento - Orientador: Prof. Dr. Alberto Consolaro/

71- NISSAN, R. et al. Ability of bacterial endotoxin to diffuse through human dentin. J. Endod., v.21, n.2, p.62-4, Feb. 1995.

72- OGUNTEBI, B.R. Dentine tubule infection and endodontictherapy implications. Int. Endod. J., v.27, n.4, p.218-22, July 1994. 
73- OLGART, L.; BRÄNNSTRÖM, M.; JOHNSON, G. Invasion of bacteria into dentinal tubules. Acta odont. scand., v.32, n.1, p.61-70, 1974.

74- ØRSTAVIK, D.; KEREKES, K.; MOLVEN, O. Effects of extensive apical reaming and calcium hydroxide dressing on bacterial infection during treatment of apical periodontitis: a pilot study. Int. Endod. J., v.24, n.1, p.1-7, Jan. 1991.

75- PASCON, E.A.; GREMSKY, W.; LANGELAND, K. Presence of bacteria in experimentally induced periapical lesions. J.Endod., v.15, n.4, p.180, Apr. 1989. /Abstract n.48/

76- PATERSON, R.C.; WATTS, A. Further studies on the exposed germ-free dental pulp. Int. Endod. J., v.20, n.3, p.112-21, May 1987.

77- PEREZ, F. et al. Migration of Streptococcus sanguis strain throught the root dentinal tubules. J. Endod., v.19, n.6, p.297-301, June 1993.

78- PETERS, L.B.; WESSELINK, P.R.; MOORER, W.R. The fate and the role of bacteria left in root dentinal tubules. Int. Endod. J., v.28, n.2, p.95-9, Mar. 1995.

79- POTERA, C. Biofilms invade microbiology. Science, v.273, n.5283, p.17957, Sept. 1996.

80- PUMAROLA, J.; BRAU, E.; CANALDA, C. Papel de las bacterias anaerobias en la etiopatogenia de la patología pulpo periapical. Endodoncia, v.11, n.3, p.135-42, Jul./Sep. 1993.

81- RAISZ, L.G. et al. Effects of two bacterial products, muramyl dipeptide and endotoxin, on bone resorption in organ culture. Calcif. Tiss. Int., v.34, p.365-9, 1982.

82- RIETSCHEL, E.T.; BRADE, H. Bacterial endotoxins. Sci. Amer., v.267, n.2, p.26-33, Aug. 1992. 
83- RIVERA, E.M.; ZERR, M.A.; DRAKE, D.R. Antimicrobial effects of calcium hydroxide after repeated exposure to pathogens. J.Endod., v.22, n.4, p.201, Apr. 1996. /Abstract n.51/

84- ROANE, J.B.; SABALA, C.L.; DUNCANSON, M.G. The "balanced force" concept for instrumentation of curved canals. J. Endod., v.11, n.8, p.20311, Aug. 1985.

85- ROBINSON, H.B.G.; BOLING, L.R. The anachoretic effect in pulpitis. I. Bacteriologic studies. J. Amer. dent. Ass., v.28, n.2, p.268-82, Feb. 1941.

86- RODE, S.M.; FARIA, M.R.; MONTEIRO, M.P. O uso de microondas para descalcificação de tecidos mineralizados da mandíbula de ratos. Rev. Odont. USP, v.10, n.1, p.15-8, jan./mar. 1996.

87- SAFAVI, K.E.; SPANGBERG, L.S.W.; LANGELAND, K. Root canal dentinal tubule desinfection. J. Endod., v.16, n.5, p.207-10, May 1990.

88- SCHONFELD, S.E. et al. Endotoxic activity in periapical lesions. Oral Surg., v.53, n.1, p.82-7, Jan. 1982.

89- SCHOUBOE, T.; MACDONALD, J.B. Prolonged viability of organisms sealed in dentinal caries. Arch. oral Biol., v.7, p.525-6, July/Aug. 1962.

90- SCHWAB, J.H. Phlogistic properties of peptidoglycan-polysaccharide polymers from cells walls of pathogenic and normal flora bacteria which colonize humans. Infect. Immun., v.61, n.11, p.4535-9, Nov. 1993.

91- SELTZER, S.; BENDER, I.B. The dental pulp. 2.ed. Philadelphia, J. B. Lippincott, 1965. p.106-21.

92- SEN, B.H.; PISKIN, B.; DEMIRCI, T. Observation of bacteria and fungi in infected root canals and dentinal tubules by SEM. Endod. dent. Traumat., v.11, n.1, p.6-9, Feb. 1995.

93- SHINDELL, E. A study of some periapical roentgenolucencies and their significance. Oral Surg., v.14, n.9, p.1057-65, Sep. 1961. 
94- SIQUEIRA JÚNIOR., J.F.; UZEDA, M.; FONSECA, M.E.F. A scanning electron microscopic evaluation of in vitro dentinal tubules penetration by selected anaerobic bacteria. J. Endod., v.22, n.6, p.308-10, June 1996.

95- STABHOLZ, A.; SELA, M.N.; The role of oral microorganisms in the pathogenesis of periapical pathosis. I. Effect of Streptococcus mutans and its cellular constituents on the dental pulp and periapical tissue of cats. $\mathbf{J}$. Endod., v.9, n.5, p.171-5, May 1983.

96- STASCHENKO, P. The role of immune cytokines in the pathogenesis of periapical lesions. Endod. Dent. Traumat., v.6, n.3, p.89-96, June 1990.

97- SUNDQVIST, G. Association between microbial species in dental root canal infections. Oral microbiol. Immunol., v.7, n.5, p.257-62, Oct. 1992.

98- SUNDQVIST, G. Taxonomy, ecology, and pathogenicity of the root canal flora. Oral Surg., v.78, n.4, p.522-30, Oct. 1994.

99- SUNDQVIST, G.; JOHANSSON, E.; SJÖGREN, U. Prevalence of Blackpigmented Bacteroides species in root canal infections. J. Endod., v.15, n.1, p.13-9, Jan. 1989.

100- TAYLOR, R.D. Modification of the Brown and Brenn Gram stain for the differential staining of Gram-positive and Gram-negative bacteria in tis sue sections. Amer. J. clin. Path., v.46, n.4, p.472-4, Oct. 1966.

101- TORABINEJAD, M.; UNG, B.; KETERRING, J.D. In vitro bacterial penetration of coronally unsealed endodontically treated teeth. J. Endod., v.16, n.12, p.566-9, Dec. 1990.

102- TRONSTAD, L.; BARNETT, F.; CERCONE, F. Periapical bacterial plaque in teeth refractory to endodontic treatment. Endod. dent. Traumat., v.6, n.2, p.73-7, Apr. 1990.

103- TRONSTAD, L.; KRESHTOOL, D.; BARNETT, F. Microbiological monitoring and results of treatment of extraradicular endodontic infection. Endod. dent. Traumat., v.6, n.3, p.129-36, June 1990. 
104- TZIAFAS, D. Experimental bacterial anachoresis in dog dental pulps capped with calcium hydroxide. J. Endod., v.15, n.2, p.591-5, Dec. 1989.

105- VONGSAVAN, N.; MATTHEWS, B.; HARRISON, G.K. Decalcification of teeth in a microwave oven. Histochem. J., v. 22, p.377-80, 1990.

106- WALTON, R.E.; ARDJMAND, K. Histological evaluation on the presence of bacteria in induced periapical lesiones in monkeys. J. Endod., v.18, n.5, p.216-21, May 1992.

107- WAYMAN, B.E. et al. A bacteriological and histological evaluation of 58 periapical lesions. J. Endod., v.18, n.4, p.152-5, Apr. 1992.

108- WIJNBERGEN, M.; VAN MULLEM, P.J. Effect of histological decalcifying agents on number and stainability of Gram-positive bacteria. J. dent. Res., v.66, n.5, p.1029-31, May 1987.

109- WIJNBERGEN, M.; VAN MULLEM, P.J. The cumulative effect of disinfection, storage, histological fixation and demineralization on number and staining ability of Gram-positive bacteria. Int. Endod. J.; v.24, n.5, p.243-8, Sept. 1991.

110- WINKLER, T.E.; MITCHELL, D.E.; HEALEY, H.J. A bacterial study of human periapical pathosis employing a modified Gram tissue stain. Oral Surg., v.34, n.1, p.109-16, July 1972.

111- WITTGOW, W.; SABISTON, C.B. Microorganisms from pulpal chambers of intact teeth with necrotic pulps. J. Endod., v.1, n.5, p.168-71, May 1975.

112- YAMASAKI, M. et al. Endotoxin and Gram-negative bacteria in the rat periapical lesions. J. Endod., v.18, n.10, p.501-4, Oct. 1992.

113- ZAVITOSKI, J. et al. Quantitative bacteriology of endodontic infections. Oral Surg., v.49, n.2, p.171-4, Feb. 1980. 
ABSTRACT 


\section{ABSTRACT}

Bacteria play a major role in the pathogeneses of pulpal and periapical diseases. The purpose of this study was to analyze bacterial arrangement in the hard structure of non-vital teeth with apical granulomas. We used 32 tooth roots with periapical lesions firmly adhered to them. For this study we also used 16 lesions, in slices obtained with the purpose of diagnosis, with compatible diagnosis of apical granulomas. The specimens were analyzed through optical microscopy using hematoxilin-eosin, and Brown and Brenn stain techniques. The results of this study showed a great number of Gram positive and Gram negative bacteria at the lumen of the main root and accessory canals; less amount in the dentinal tubules, in lacunae of the cellular cementum, on the root surface, and apical granulomas.

Considering the metodology applied, our findings showed:

1 - A high frequency of bacteria in apical canal roots, where predominated Gram positive and Gram negative cocci and rods, distributed isolated or in bacterial colonies, sometimes attached in the wall canal root;

2 - In roots cutted in a transversal way we found the presence of Gram positive and Gram negative cocci and rods in dentinal tubules of the root third apical expanding to the third pulpal through the superficial layer dentin. 
3 - The presence of Gram positive and Gram negative in the external surface of apical dentin root distributed isolated or plaques firmly adhered, where cocci and rods predominated.

4 - The presence of Gram positive and Gram negative, mainly cocci and rods, arranged in colonies or isolated in the external cellular spaces or within macrophage cells.

Hence, we concluded that in teeth with necrotic pulps and apical granulomas the bacteria wrap up all root canal system includind dentinal tubules and the periapical region. This study enhanced once more the need of mechanical cleaning aided by chemical irrigation, antibacterial intracanal dressings and adequate filling of the root canal system in non-vital teeth with chronic periapical lesions. 